Illinois State University

ISU ReD: Research and eData

Theses and Dissertations

Summer 8-2005

\title{
Where the Green Money Grows: Assessing the Prospects of Ecotourism in Gabon
}

Daniel Chand

Illinois State University

Follow this and additional works at: https://ir.library.illinoisstate.edu/etd

Part of the Other Political Science Commons

\section{Recommended Citation}

Chand, Daniel, "Where the Green Money Grows: Assessing the Prospects of Ecotourism in Gabon" (2005). Theses and Dissertations. 445.

https://ir.library.illinoisstate.edu/etd/445

This Thesis is brought to you for free and open access by ISU ReD: Research and eData. It has been accepted for inclusion in Theses and Dissertations by an authorized administrator of ISU ReD: Research and eData. For more information, please contact ISUReD@ilstu.edu. 
WHERE THE GREEN MONEY GROWS: ASSESSING THE PROSPECTS OF ECOTOURISM IN GABON

DANIEL CHAND

A Thesis Submitted in Partial Fulfillment of the Requirements for the Degree of

MASTER OF SCIENCE

Department of Politics and Government

ILLINOIS STATE UNIVERSITY

2005 
THESIS APPROVED:

Date $\quad$ Robert Hunt, Chair

Date Lucinda Beier

Date Ali Riaz 

WHERE THE GREEN MONEY GROWS: ASSESSING THE PROSPECTS OF ECOTOURISM IN GABON

\section{Daniel Chand}

196 Pages

August 2005

An examination of the challenges to ecotourism development in the West-Central African nation of Gabon.

APPROVED:

Date

Robert Hunt, Chair

Date

Lucinda Beier

Date

Ali Riaz 
WHERE THE GREEN MONEY GROWS: ASSESSING THE PROSPECTS OF ECOTOURISM IN GABON

\section{Daniel Chand}

196 Pages

August 2005

This is an examination of the challenges to ecotourism development in the West-Central African nation of Gabon. This study uses secondary analysis of past literature and utilizes primary, qualitative research in the form of surveys of experts on the subjects of ecotourism, sustainable development, and the Congo Basin.

APPROVED:

Date

Date

Date
Robert Hunt, Chair

Lucinda Beier

Ali Riaz 


\section{ACKNOWLEDGMENTS}

Foremost I would like to thank Dr. Robert Hunt for serving as my committee chair and providing guidance to me. He was always willing to help with the process of completing this thesis, even long before I chose the topic. I would also like to thank my two committee readers, Dr. Lucinda Beier and Dr. Ali Riaz, for their thorough reading, constructive criticism, and for always being available whenever I had questions.

I would like to thank all of the participants who took the time to answer my research questions. Their opinions were invaluable to my findings. While working on this manuscript, there were a number of occasions where I had questions about the logistical process of completing a thesis. I would like to thank Beverly Beyer for helping me get through some of these bumps in the road. I would also like to thank Sandra Nichols at WildLaw for helping me to proof read the entire manuscript.

Thank you all.

D.C. 
CONTENTS

Page

ACKNOWLEDGMENTS $\quad$ i

CONTENTS $\quad$ ii

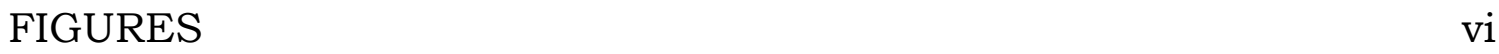

PREFACE 1

CHAPTER

$\begin{array}{ll}\text { I. INTRODUCTION } & 10\end{array}$

Study Methodology 13

$\begin{array}{ll}\text { The Participants } & 18\end{array}$

Limitations 19

$\begin{array}{ll}\text { Contributions } & 20\end{array}$

II. A DISSCUSSION OF ECOTOURISM 23

Culture Clash $\quad 30$

Profits or Conservation: What is the Primary Objective? 37

Plugging Up Leaks $\quad 42$

Withstanding the Unpredictable $\quad 45$

III. GETTING TO KNOW GABON 51

Gabon's Population $\quad 54$

The Economic Conundrum $\quad 55$

Alternative Sources of Income 58

Gabon's Colonial History $\quad 62$

Gabon's Pseudo Independence 65

Bongo's Continuation of French Influence 68

The Residue of Colonialism $\quad 72$

ii 
Post-colonial Gabon's Ecotourism Challenges $\quad 79$

Political Corruption $\quad 79$

Severe Stratification $\quad 81$

A Decimated Culture $\quad 83$

Child Slave Labor $\quad 84$

Sex Trade $\quad 85$

Lack of Rural Development $\quad 86$

Traveling To and Around Gabon $\quad 88$

Price Gouging $\quad 90$

No International Image $\quad 90$

The "Meatiest" Problem 91

Tourism Impacts of Bushmeat $\quad 99$

Accomplishments So Far 104

Akanada National Park 105

Ivindo National Park 105

Loango National Park 106

Lopé National Park 106

Mayumba National Park 107

Bateke Plateaux National Park 107

Minkebe National Park 107

Help Is On the Way 108

A Long Way to Go 109

IV. COSTA RICA: A DEVELOPMENT AND MANAGEMENT CASE STUDY

Costa Rica's Head Start $\quad 122$

A History of Costa Rica 123

Muted Effects of Colonialism 125

Democratization and Social Rights 127

Costa Rica Today 129

Ecotourism's Development and Management Model 131

Developing Support for Conservation 136

The Successful Management Model 138

The True Eco-experience 141

Not All Good News in Paradise 142

Under Developed 142

Overly Developed 144

Private Reserves 148

The Problems With Packages 151

The Ecotourism Yellow Brick Road 151

iii 
$\begin{array}{ll}\text { V. CONCLUSION } & 157\end{array}$

$\begin{array}{ll}\text { Political Development } & 161\end{array}$

Democracy and political and social rights $\quad 162$

Local empowerment and social stratification $\quad 164$

$\begin{array}{ll}\text { Limited Accessibility } & 166\end{array}$

Direct flights from United States and more of Europe 167

In-country travel infrastructure 167

$\begin{array}{ll}\text { Getting visas } & 168\end{array}$

$\begin{array}{ll}\text { Local Education and Investment } & 168\end{array}$

The primary goal is preservation, not profit $\quad 169$

Sustaining the environment 169

Sustaining culture $\quad 170$

Developing local managers $\quad 171$

Developing local interest $\quad 171$

$\begin{array}{lr}\text { Staying Small } & 172\end{array}$

Limited development around parks $\quad 172$

Promoting small business 172

$\begin{array}{ll}\text { Gabon's Image } & 175\end{array}$

Price gouging $\quad 175$

Hunting of rare wildlife $\quad 176$

Marketing Gabon 178

$\begin{array}{ll}\text { Agricultural Problems } & 178\end{array}$

Helping Farmers 178

$\begin{array}{ll}\text { Controlling logging } & 180\end{array}$

$\begin{array}{ll}\text { Economic Diversification } & 181\end{array}$

$\begin{array}{ll}\text { Putting your eggs in one basket } & 181\end{array}$ 
APPENDIX C: Survey for Experts on Environmental Protection or Ecotourism

APPENDIX D: Survey for Experts on Gabon or Congo Basin 


\section{FIGURES}

Figure $\quad$ Page

1. Gabon map adapted from Mapquest 51

2. National parks map adapted from park service's website 105

3. Costa Rica map adapted from Mapquest 119

4. Tortuguero National Park map adapted from Costa Rica Map and Travel Guide website 138 


\section{PREFACE}

Throughout this thesis, I refer to my experiences with WildLaw working to promote ecotourism to Gabon. I would like to use this preface to explain how I started working to promote ecotourism in Gabon and, consequently, ended up writing about ecotourism. My academic and professional work background has not dealt with ecotourism. Before I began this study, the ecotourism was new to me; yet, I soon developed an interest in the subject.

I came to work for WildLaw, a nonprofit, environmental law firm based in Montgomery, Alabama, through a former employer who, at the time I was hired, was the organization's development director. (For the purpose of this paper, I will refer to this person as Bill.) Bill was in charge of WildLaw's fundraising and development projects. Bill did not have much experience with grant writing or other typical fundraising strategies for nonprofits such as WildLaw. As a result, he was continually on the search for a moneymaking venture that he thought would serve as a steady source of income for WildLaw.

One day while reading his National Geographic, Bill noticed a story on the pristine, untouched rainforest of the Central African country of 
Gabon. The government of Gabon, he discovered, was hoping to establish itself as the newest addition to the list of major ecotourism destinations. At this point, however, Gabon was essentially unheard of in tourism circles. There were a number of conservation organizations working on environmental protection and research in Gabon. But there currently was not a single nonprofit recruiting individuals to travel to Gabon. "How interesting," he thought. There are conservation nonprofits recruiting travelers and organizing trips to places like Costa Rica, the Galapagos Islands, Kenya, and various other places. Many had made large profits working with ecotourism. Bill had devised a plan. "If WildLaw were the first to organize tours to Gabon," he thought, "it could stand to make a lot of money."

In late 2003, I began looking for a professional practice to finish my master's degree. I started calling people I knew to see if anyone knew of any job openings. One of the people I called was Bill. He informed me that he was working for a nonprofit in Montgomery that was embarking on a major project. The organization was working on developing ecotourism in the Congo Basin—and he thought there could be a job on the project for me. Needless to say, it all sounded very exciting. As I said, I did not know anything about ecotourism, but it did not matter. My job, Bill explained, would deal more with researching prospective tourists and some administrative duties. 
At first I knew next to nothing about the organization for which Bill was working. In fact, I did not even know the name. I assumed it was some type of international conservation nonprofit. Later I discovered that it dealt entirely with domestic issues. In fact, it was a law firm. The normal duties for its staff were activities such as reviewing environmental impact statements and bringing legal actions against government agencies such as the National Forest Service. It seemed peculiar to me that a nonprofit that had nothing to do with international conservation or tourism was embarking on a major venture in another country. But I went along with it anyway, assuming that the people involved knew what they were doing.

I arrived in Montgomery in February 2004 and hit the ground running. Before I even arrived, I was already reading every ecotourism or Gabon-related piece of literature I could find. I immersed myself in my work, determined to make the project a success. Shortly after I began my work, however, I started to realize my optimism in the project was somewhat misplaced. WildLaw was a moderate-sized organization. Its operating budget was roughly $\$ 500,000$ a year. In addition to its office in Montgomery, the organization's main office, it also had offices in Florida, Virginia, North Carolina, and Utah. WildLaw had a decent amount of money for a legal nonprofit, but it has never had the type of money it takes for such an ambitious initiative as establishing ecotourism in Gabon. From my experience with WildLaw's Gabon 
project, efforts at creating ecotourism programs are best left to organizations like Conservation International, with multi-million dollar budgets.

WildLaw's project was christened Destination: Gabon. The idea sounded simple enough, which is probably how the project was even allowed to get started. WildLaw would recruit environmentally conscious individuals to travel to Gabon. Needless to say, implementing this plan was not so simple. WildLaw was going to organize one trip to Gabon for July 31 through August 8, 2004. Since there are no direct flights to Gabon, Bill had the idea to charter an airplane to take all the travelers. Chartering a plane meant that the cost of the trip would increase dramatically. Since the organizers were hoping to at least breakeven on this first trip (they anticipated additional trips in years to come) the total number of travelers had to be large to offset the cost of a private, chartered jet. It was estimated that WildLaw would need approximately 150 people to travel to Gabon on this first trip to make any profit. Since it is only slightly less than impossible to lead a group of more than 100 people on a tour of a rainforest, the organizers hoped to develop several different travel tracks consisting of groups of eight to 16 people.

In January 2004, WildLaw had sent a group of representatives on what was described as a reconnaissance trip to Gabon. The representatives were Bill, a consultant hired by WildLaw who was a friend of Bill's, and a staff attorney who spoke French and had recently 
served in the Peace Corps in Côte D'Ivoire. Also on the trip was a member of the ecotravel organization Tropical Nature Travel, based in Baltimore, Maryland. WildLaw was working with Tropical Nature and an organization in Gabon called Mistral Voyages to put together tours of the country's national parks. The purpose of the trip was to map out travel tracks for the anticipated large group of tourists WildLaw was going to bring to Gabon.

By the time I arrived in February, staff members thought they had all the points of the trip worked out. For a cost of $\$ 6,850$ per person, WildLaw would fly travelers in a chartered aircraft from Atlanta to Gabon. The cost of the trip covered all airfare, including the cost of a coach ticket from anywhere in the United States to Atlanta; all hotel accommodations and meals in Gabon; all in-country air and ground transportation; assistance in obtaining a Gabonese visa; access to tour interpreters, a physician, and in-country environmental experts; access to satellite phones; a one-year membership to WildLaw; and tax deductibility of up to $\$ 1,000$.

\section{A Case of Mission Drift}

During my time working with Destination: Gabon, I was repeatedly asked why an environmental law firm based in Montgomery, Alabama was getting involved with an international ecotourism venture. At great pains I attempted to answer this question without using the words "fundraising scheme," which is essentially what the project was. Alan 
Fowler describes the phenomenon of "mission creep" as inconsistency between mission and action on the ground and internal confusion resulting from a gap between rhetoric and reality. ${ }^{1}$ Rob Johnston, with the Drucker Foundation, describes the characteristics of the same phenomenon ("mission drift" as he calls it) as not using the mission as a daily discipline, pursuing opportunities even if they do not further the mission, and not being able to determine the mission of the organization from its actions. ${ }^{2}$ As Johnston explains, entrepreneurial organizations may find themselves suffering from mission drift after pursuing new funding opportunities. One could accuse WildLaw of mission drift for undertaking Destination: Gabon; however, I am not sure that WildLaw was drifting away from its mission as much as it was driving full force in a totally new direction. WildLaw and the people involved with Destination: Gabon had nothing to do with ecotourism, even in the United States, much less on other continents. The people involved with the project, and this was a small number, were completely clueless on how to properly create an ecotourism model. I too was clueless, although the structure of the project was already decided long before I arrived.

As far as I could tell, WildLaw's project did not copy any other nonprofit ecotourism models. The project's design seemed almost entirely original. This unfortunately meant the design contained a great number of mistakes. A good example of a mistake in the design was the idea of having a chartered aircraft take hundreds of people to Gabon for 
a one-time trip. While conducting research for this thesis and for Destination: Gabon, I discovered many nonprofits that dabbled in ecotourism or operated ecotourism programs. Of all the nonprofit, ecotourism programs I researched, not one used a chartered plane to carry travelers to a destination. The overwhelming majority had travelers book their own flights to the host country, although some groups offered to help with the booking process. The litany of mistakes in Destination: Gabon's design is way too extensive to recount here; but needless to say, that list alone is proof enough that WildLaw should not have been involved with ecotourism in Africa.

Of course, there is nothing wrong with enterprising fundraising ideas, as long as they fall within the mission of the organization. But even if Destination: Gabon had been within the mission of WildLaw, it still would not have been worth the cost of the initiative. According to the essay "Understanding Risk, the Social Entrepreneur, and Risk Management," by Jed Emerson, funding risks include such factors as:

- "The amount of funds necessary to support the enterprise

- Whether or not those funds are readily available

- The amount of cash flow necessary to support the operation during its period of startup and expansion." 3

As Emerson puts it, organizations must assess all the cost involved with a fundraising venture to determine if it is truly worth the 
risk. If those who were responsible for Destination: Gabon had examined the three criteria above and considered all the staff time and energy that would be necessary, WildLaw would most likely not have become involved with the project.

The purpose of this study is not a critical examination of WildLaw's brief foray into international ecotourism. But I did feel I should explain how I became involved with this topic. It should also be noted that WildLaw does great environmental legal and outreach work in the United States. Rather this study seeks to examine the prospects of ecotourism as a development model in Gabon. Can Gabon become a major ecotourism destination? If so, what steps will it have to take to get there? There will be a role for NGOs in the West to play if ecotourism is to thrive in Gabon and benefit the average Gabonese. This study in part attempts to explain what role NGOs should have in this process. While WildLaw had no business getting involved with ecotourism in Gabon, other more appropriate nonprofits will need to step up to the plate. 
Notes

1 Alan Fowler, "Options, Strategies and Trade-offs in Resource Mobilization," in The Earthscan Reader on NGO Management, ed. Michael Edwards and Alan Fowler (Sterling, VA: Earthscan Publications Ltd, 2002), 374.

2 Rob Johnston, "Defining Your Mission," in Enterprising Nonprofits: A Toolkit for Social Entrepreneurs, ed. J. Gregory Dees, Jed Emerson, and Peter Economy (New York: John Wilety \& Sons, 2001), 34.

3 Jed Emerson, "Understanding Risk: The Social Entrepreneur and Risk Management," in Enterprising Nonprofits: A Toolkit for Social Entrepreneurs, ed. J. Gregory Dees, Jed Emerson, and Peter Economy (New York: John Wilety \& Sons, 2001), 139. 


\section{CHAPTER I}

\section{INTRODUCTION}

"The ethical person shatters no ice crystal that sparkles in the sun, tears no leaf from its tree, breaks off no flower, and is careful not to crush any insect as he walks."

- Albert Schweitzer (1875-1965), Philosophy of Civilization: Civilization and Ethics, 1923

On August 1, 2002, the President of the West-Central African Republic of Gabon, El Hadj Omar Bongo, one of the longest ruling heads of state in the world, called an unexpected meeting of his government ministers to discuss an urgent financial matter. Also attending the meeting were two Western environmentalists who had by that point become well known to all members of the Gabonese government and business community. One was British biologist Lee White, the head of the Gabon program set up by New York-based NGO the Wildlife Conservation Society (WCS). The other was American ecologist Michael Fay, internationally known for his 3,220-kilometer trek (2,000 miles) across Gabon. On the agenda for the day's meeting was a new and exciting opportunity for the country to offset its slumping petroleum revenues and rising national deficits: ecotourism. 
Upon the recommendation of his Western visitors, the President announced to the surprise of everyone in attendance-including Fay and White-that he wanted to establish 13 new national parks. These 13 new national parks were to become the backbone of the country's newest financial sector. One that, it was hoped, would become the driving force of the Gabonese economy and recreate the country's international identity. After decades of heavy reliance on oil and timber industries, "we (the Gabonese) are left with little oil in the ground, a fragmented forest, dwindling income, and a burden of debt," Bongo said. The country's next major source of revenue, said the President, would be "one based on enjoying, not extracting, national resources."1 On August 30, less than a month after his cabinet meeting, President Bongo signed a decree creating 13 national parks. The moment was of such importance to the international conservation movement that National Geographic's David Quammen described it as potentially one of the most "significant conservation actions" since President Ulysses S. Grant created the world's first national park, Yellowstone, back in $1872 . .^{2}$ While it was an undoubtedly bold and admirable action, only time will be able to tell whether President Bongo's actions will usher in a new era of economic development for Gabon or go down as simply a nice attempt to fend off economic collapse and protect the country's rainforest, the last large remaining section of rainforest in the Congo Basin. 
This study seeks to examine the relationship between ecotourism and the political and economic development of Third World countries. While examining the prospects of ecotourism in Gabon, I attempt to answer the questions:

1. What is ecotourism?

2. Can ecotourism replace Gabon's timber industry and declining oil revenue?

3. What form should ecotourism take in Gabon?

4. What can be learned from ecotourism programs in other countries to inform Gabon's development of ecotourism?

In the process of answering each of these questions, this study attempts to provide examples of individual and national models for Third World ecotourism initiatives, an explanation of the common effects of ecotourism, and a detailed description of the cultural and economic composition of Gabon.

Gabon is a small West-Central African country that was formerly part of the French-controlled section of the Congo Basin. Currently its economy relies heavily on mineral extraction, primarily oil exploration. Culturally, it shares some of the same characteristics of other West and Central African countries, but environmentally its terrain is very similar to some of the rainforest environments in Central America. While answering the third and fourth questions of this study, I found myself consistently referring to Costa Rica for private ecotourism initiatives and 
national conservation efforts. For this reason, I devoted an entire chapter to discussing ecotourism in Costa Rica as a model of development. After thoroughly exploring Costa Rica's system, I came to find that the country served as a good model of ecotourism management, with examples of what to and what not to do. Costa Rica provides more than just environmental management examples. While it is environmentally similar, its historical and social differences help to explain the missing elements of Gabon's social composition that are necessary for ecotourism or any other broad development movement. These differences are explained in chapters 3 and 4 on Gabon and Costa Rica respectively.

\section{Study Methodology}

The majority of information for this study came from either academic literature on ecotourism and Gabon or from my experience working with WildLaw. However, a small yet important portion of this study's conclusions comes from primary research in the form of survey responses from a variety of individuals I contacted for this study. I decided to conduct surveys because I believed they could provide a more individualized prospective of ecotourism and Third World development that I could not obtain from source materials. I also hoped the surveys would serve as a guide to answering the questions I put forward in this study. While I was somewhat disappointed in the surveys' ability to provide a first-person explanation of ecotourism and Gabon, they did 
help guide me in the right direction for answering many of the questions I had throughout the process of writing this thesis.

I contacted approximately 30 people to participate in this study. The number of people contacted has no significance other than it was the largest number of qualified possible participants I could find and contact within the study period. Of the people I contacted, 17 offered to participate. Of those, 11 actually participated in the survey.

The people who participated in this study represent a variety of backgrounds and opinions on conservation work, ecotourism, Gabon, and economic development. All, however, fall into either one of two categories: individuals with experience in the field of ecotourism or individuals who have experience with development work in the Congo Basin. Some of the people I knew and worked with on WildLaw's ecotourism venture. Others I never met or spoke with before contacting them for this study. Nobody approached for participation in this survey was contacted before I received approval from the Illinois State University Institutional Review Board (IRB) on June 11, 2004 and no one was contacted after January 25, 2005. The majority of individuals contacted for participation in this study were contacted between June (after receiving IRB approval) and the end of August 2004. Two individuals were contacted in January, after I received a thesis extension for the spring 2005 semester. 
All of the people contacted for this study were contacted through email. This was necessary because many of the people I contacted worked or lived outside the country. When composing my thesis proposal (in January 2004) I originally planned to conduct face-to-face or phone interviews with interviewees. Shortly after I began this study, I quickly became aware that this would not be possible because of practical limitations. For example, it would cost me a great deal of money for a 30-minute phone interview with someone in Africa.

The majority of individuals who responded to my survey sent their answers through email. One printed out the survey and mailed me his responses, and one wished to answer the questions over the phone. In the case of the phone interview, I emailed my questions to the participant in advance and wrote her responses as I asked her the questions over the phone. No recording devises were used. All of the individuals I approached for this study were made aware of who I was and my reason for contacting them. Those who offered to participate were sent a copy of my IRB-approved informed consent document (Appendix B) and one of two different copies of my survey (Appendixes $\mathrm{C}$ and $\mathrm{D}$ ). Individuals with backgrounds in environmental protection or ecotourism were given a copy of what I referred to as my environmental experts survey (Appendix C). Individuals with experience in or knowledge of politics or community development in Gabon or the Congo Basin were given a copy of my Gabon experts survey (Appendix D). Both surveys asked individuals to 
draw on their professional backgrounds to answer the questions, and "If possible, please use an example of something you experienced for some of the questions."

There were seven questions on each survey. The first four questions on both surveys were the same. They were:

1. In your opinion, what would constitute a successful ecotourism program in a country such as Gabon?

2. What should be the top priority for any ecotourism program in Gabon?

3. Besides nonprofits, what steps should governments, businesses, and other institutions in the West take to establish ecotourism in Gabon?

4. What are the target groups that you believe would be interested in ecotourism in Gabon?

The last three questions on the surveys differed. This was done because I wanted this study to examine both the environmental and development impacts of ecotourism in Gabon. The last three questions on the environmental experts survey were created primarily for individuals with knowledge on conservation issues and ecotourism. These three questions were:

5. What type of a role should the local community play in any ecotourism program in Gabon? What type of role should outside groups play? 
6. From your perspective, please briefly define what ecotourism is. How does it differ from other development models?

7. What are possible negative consequences (e.g., environmental, cultural, political...) of ecotourism that you could foresee happening in Gabon?

The last three questions on the Gabon experts survey were intended for individuals with knowledge and expertise specifically relating to Gabon. They were:

5. What unique challenges does Gabon present to those trying to establish a sustainable ecotourism model?

6. In addition to ecotourism and oil, what other opportunities for economic development are available to Gabon? How do these other opportunities compare to ecotourism?

7. Briefly, what suggestions would you make to solve the bushmeat trade in Gabon?

Some of the individuals approached for the study had experience with both conservation work and the country of Gabon. In those rare cases, I provided the person with the survey that I believed would make the greatest contribution to this study. For example, if I had more environmental/ecotourism surveys filled out than Gabon surveys, I would give the individual the latter. This was not an issue that arose often. All of the survey responses, including the mailed and phone responses, have since been placed on my work computer, which I used to 
write this thesis. This computer requires a password to be used, which only I know. Backups of each of these survey responses exist in my work email, which also requires a password.

\section{The Participants}

The individuals who responded to my surveys have widely varied backgrounds, yet all of them provided valuable contributions to my research. Four of them were academics that dealt with ecotourism. The others included: a Ph.D. biologist who heads the work of the Wildlife Conservation Society (WCS) in Gabon; an advocate and author who runs a nonprofit she founded that addresses the effects of tourism on indigenous people; a political science professor at a major Mid-Western University whose area of expertise was francophone Africa; a currently serving Peace Corps volunteer in Gabon; a tour guide in Gabon; an anthropology Ph.D. candidate at the University of Virginia who has lived in and done development work in Gabon; and a forest ranger for a national forest in the United States.

On several occasions I quoted these people within the text of this thesis. Most of the time I did not use the name of the participant. Usually I would identify these individuals by referring to them by what they do, such as "a Peace Corps volunteer" or "a district ranger for a national forest." On these occasions where I did not use a participant's name, it was because I did not feel would have added anything extra to the information he or she provided or changed the significance of the 
quote. On the few occasions where I did quote someone by name from the surveys, it was because the individual was a prominent authority in the area of ecotourism or conservation. In those cases, I felt the source of the information added extra significance to the information provided. There are occasions throughout this thesis where I use a direct quote with a name attached that I did not take from any of my surveys. On these occasions, the quote was lifted from previous literature and is followed with a citation.

Lastly, while working with WildLaw's Gabon project, I was repeatedly told information that I believed was invaluable to this thesis. This presented me with somewhat of a dilemma. On one hand, I wanted to use the information in either a quote or paraphrase because I believed it added to the overall value of my research. On the other hand, these individuals had not necessarily been informed that I was working on a thesis and did not give me consent to use the information they provided to me. After consulting with a member of my thesis committee who in turn consulted with a member of Illinois State's IRB, I was told it was acceptable to quote individuals who provided information regarding ecotourism and Gabon as long as I did not use their names if they were unaware I planned to use the information in the thesis.

\section{Limitations}

There are several limitations to this study. Two of the obvious limitations are time and money. I would have much rather called 
individuals around the country and in Africa to participate in this study and conducted 30 to 45 -minute interviews. Financial constraints, however, made this unfeasible. The number of survey responses is also a limitation on the findings of this study. While I made attempts, and succeeded, to obtain survey responses from individuals with a variety of backgrounds and opinions, the small number of surveys in no way represents a scientific sampling of opinions on this matter. To provide such a representation of opinions would require a large empirical study, which is more than I am capable of providing by myself.

When I wrote the proposal for this thesis, I said that there was very little if any academic literature that existed on ecotourism in Gabon or the prospects thereof. This is still true. The academic literature on Gabon is quite small in comparison to most African countries or other countries in the region. For this reason, I do not believe this thesis will have much bases for comparison. There is, however, a growing amount of non-academic literature about ecotourism in Gabon. This is mainly because of the efforts of environmental groups that are working to turn the country into an ecotourism destination.

\section{Contributions}

This thesis will be valuable to researchers looking for models upon which to develop environmentally safe and sustainable development programs in parts of the global South, particularly the Congo Basin. It adds to the rapidly growing pool of literature on ecotourism, specifically 
adding to literature on ecotourism development in Africa. It also contributes to the discussion on sustainable development strategies in post-colonial Africa. Researchers interested in this subject will be able to find discussions of development challenges and a number of Third World development approaches in chapters 3 and 5. 
Notes

1 David Quammen, "Saving Africa's Eden," National Geographic, September 2003, 64.

2 Ibid., $63-64$. 


\section{CHAPTER II}

\section{A DISCUSSION OF ECOTOURISM}

"What is "ecotourism"? While researching this topic, I asked author and well-known ecotourism expert Paul F.J. Eagles essentially the same question. His answer was brief, simple and very pithy: "This question has been asked and answered ad nauseum in the last 20 years." For that reason, I apologize in advance for any experts on ecotourism who have read and reread discussions on this question a countless number of times. Since the purpose of this study is not to again define what ecotourism is, but rather examine one economic possibility for Gabon, I will try to be brief in my attempt to clarify what ecotourism means to me and how best the term applies to somewhere such as Gabon. In addition, this chapter also contains a discussion of some of the common problems associated with ecotourism in the developing world.

To hear some people talk about it, ecotourism is the greatest development concept to come out of the twentieth century. It has been touted as the cure-all solution for an array of problems including funding conservation and scientific research, protecting important and fragile environments, contributing to Third World economic development, and 
creating environmental awareness with tourists and host countries. ${ }^{1}$ It is also fast becoming a desired alternative to ordinary tourist activities. Advanced by the United Nations' 1992 Earth Summit in Rio de Janeiro, ecotourism grew by leaps and bounds in the 1990s. In 1997, the World Tourism Organization (WTO) estimated that ecotourism is increasing at an estimated rate of 10 to 30 percent a year, ${ }^{2}$ which was about two to five times the rate of growth for tourism in general. The next year, the WTO projected that tourism accounted for 20 percent of world travel. ${ }^{3}$ The year 2002 was declared the "International Year of Ecotourism" by the United Nations. ${ }^{4}$ The growth continues still. In 2004, it was projected that the ecotourism market is growing at a rate three times higher than the tourism industry as a whole and is predicted to be a full 5 percent of the whole tourism market in the next 10 to 20 years. ${ }^{5}$

Besides the United Nations, other international organizations that have a stake in ecotourism include the World Health Organization, the International Civil Aviation Organization, the Organization of American States, the Organization for Economic Cooperation and Development, the World Travel and Trade Council, the Overseas Private Investment Corporation, the Corporate Council on Africa, and the Pacific Asia Travel Association. Ecotourism is also becoming a popular public relations cause for Fortune 500 companies. In my time working with WildLaw, I discovered a number of large, international corporations that are involved with sponsoring ecotourism programs, including Starbucks, 
McDonald's, Ford Motor Company, Anheuser-Busch, Exxon Mobil, Citigroup, Sony, the Gap, Hyatt Hotels and Resorts, United Airlines, and Hilton Hotel Corporation.

Although the origins of the term ecotourism are not entirely clear, from most accounts the practice of ecotourism came about as part of the blossoming environmental movement of the 1970s and 1980s. ${ }^{6}$ It was at this time that growing concern over the environmental impacts of mass tourism caused less-developed countries to realize that environmentally friendly tourism may be an effective means to sustainable development. ${ }^{7}$ In the Amazon region of Latin America, scientists and environmentalists were becoming alarmed by deforestation through activities such as logging, oil drilling, mining, and human encroachments. ${ }^{8}$

There is no single definition of ecotourism, but there is a consistency within most popular definitions. R.K. Blamey states that the first known appearance of the term ecotourism was in 1965 by Nicolas Hetzer, who identified four "pillars" of responsible tourism: (1) minimizing environmental impacts, (2) respecting host cultures, (3) maximizing the benefits to local people, and (4) maximizing tourist satisfaction. ${ }^{9}$ The first formal definition of ecotourism, however, is credited to Mexican architect and ecotourism expert Hector Ceballos-Lascuráin. CeballosLascuráin identified ecotourism as "travel to relatively undisturbed or uncontaminated natural areas with the specific objective of studying, 
admiring, and enjoying the scenery and its wild plants and animals, as well as any existing cultural manifestations found in these areas."10

Other authors have also stressed the importance of drawing a distinction between ecotourism and other forms of sustainable, naturebased outdoor recreational activities. Because of the popularity of activities such as car camping and adventure tourism, many in the tourism industry have succumbed to the idea of placing all outdoorbased tourism experiences under the umbrella of ecotourism. ${ }^{11}$ While arguments can be made for and against the position that these activities constitute ecotourism, most serious ecotourists and researchers would argue that these activities do not constitute ecotourism. They are also not the type of activities likely to be found in an environment like Gabon. Someone may rightly define an activity such as car camping as ecotourism in the United States, in the sense that it is somewhat naturebased; however, it is highly unlikely to succeed in a rainforest where visitors are hoping to see wild gorillas. Martha Honey, the executive director of the International Ecotourism Society in Washington, does a good job of distinguishing between ecotourism and these other popular outdoor activities. Whereas these other forms of tourism "are defined solely by recreational activity of the tourist," ecotourism is defined by its benefits to conservation and the local community. ${ }^{12}$

Within the last 30 years, a number of groups dedicated to the study of nature-based tourism have attempted to explain what exactly 
constitutes ecotourism. Possibly the most widely accepted definition of ecotourism is the one presented by International Ecotourism Society (IES) in 1991. The IES describes ecotourism as "responsible travel to natural areas that conserves the environment and improves the wellbeing of local people."13 At the heart of the IES's definition is the idea of tourism providing substantial benefits for both conservationists and the local community. The IES identifies the same principles of ecotourism as Hetzer, with the additional principles of raising sensitivity about the host country's political, environmental, and social climate; providing financial benefits to the cause of conservation; and supporting international human rights and labor agreements.

The Ecotourism Association of Australia (EAA) defines ecotourism as, "Ecologically sustainable tourism that fosters environmental and cultural understanding, appreciation, and conservation."14 The National Ecotourism Strategy of Australia (NESA) identifies ecotourism as "naturebased tourism that involves education and interpretation of the natural environment and is managed to be ecologically sustainable." According to the NESA, "natural environment" includes cultural components and "ecologically sustainable" refers also to an appropriate return to the local community and long-term conservation. ${ }^{15}$

At the Quebec Ecotourism Summit of 2002, more than 1,000 delegates from public, private, and nongovernmental organizations and from 132 countries attended to draft ecotourism guidelines to be used at 
the Johannesburg Summit later that year. Not coincidentally, the Johannesburg Summit was also where Bongo announced Gabon's ecotourism strategy. (The Quebec Summit's final declaration can be read on the web at: http://www.world-tourism.org/sustainable/ ecotourism2002/eng.pdf.) According to the participants, ecotourism "embraces the principles of sustainable tourism, concerning the economic, social and environmental impacts of tourism. It also embraces the following specific principles, which distinguish it from the wider concept of sustainable tourism:

- Contributes actively to the conservation of natural and cultural heritage,

- Includes local and indigenous communities in its planning, development and operation, and contributing to their well-being,

- Interprets the natural and cultural heritage of the destination to visitors,

- Lends itself better to independent travelers, as well as to organized tours for small size groups."16

Similar to the Quebec Deceleration is the Institute for Central American Studies' “code of ethics for sustainable tourism." While the Institute's code of ethics was primarily meant to apply to tourism in 
Central American, it is applicable in any ecotourism destination. The code of ethics is as follows:

- Tourism should be culturally sensitive

- Tourism should be a positive influence on the local communities.

- Tourism should be managed and sustainable.

- Waste should be disposed of properly.

- Wildlife and natural habits must not be needlessly disturbed.

- There must be no commerce in wildlife, wildlife products, native plants, or archaeological artifacts.

- Tourists should leave with a greater understanding and appreciation of nature, conservation, and the environment.

- Ecotourism should strengthen conservation efforts and enhance the natural integrity of places visited. ${ }^{17}$

Of all the articles, books, and other documents I have read to address this subject, the best criteria of ecotourism that I have found is by Ralf Buckley, who described the criteria of ecotourism as "a naturebased product or setting; active management to reduce environmental impacts; an environmental education component; and a direct or indirect contribution to conservation of the natural environment, which 
commonly requires close cooperation with and practical benefits for local communities." 18

As illustrated by this small sample of ecotourism definitions, a variety of principles remain constant in the discussion of what constitutes ecotourism. Blamey explains, however, that there are three constant and essential principles of any ecotourism program: (1) that it is nature based, (2) that it is environmentally educated, and (3) that it is managed in a sustainable manner. ${ }^{19}$ This final principle, Blamey states, applies to the sustainability of both natural and cultural environments involved in supplying the ecotourism experience. Blamey's description, while not only simple, also seems to be the most practical definition of ecotourism in a rural rainforest environment such as Gabon's. However, one might also add to Blamey's definition one other principle of ecotourism that appears to be a constant in all definitions and all successful programs. This principle, while not always expressly stated, does seem to be present in almost every definition of ecotourism. As stated by Mark Orams, inherent in almost all definitions of ecotourism is the suggestion that ecotourism is attempting to "do the right thing." 20 With the addition of this last altruistic principle, we now have a workable definition for ecotourism in Gabon.

\section{Culture Clash}

The environment is not the only thing in Third World tourism destinations that needs protecting. Ecotourism is often designed to seek 
out the most pristine and uncharted places on Earth. Located in these parts of the world, however, are often isolated and fragile civilizations. Many past tourism ventures in developing countries have had devastating impacts on the culture of locals who are swept up in the new wave of economic development. Any list of criteria used to test the sustainability of an ecotourism venture should examine the effects of tourism on the local culture. According to Peter Murphy, the long-term success of tourism ventures depends upon the acceptance and support of host communities. ${ }^{21}$ No ecotourism program is really sustainable if the uniqueness of the local culture does not survive. Some of ecotourism's harshest critics have argued that ecotourism is really mass tourism in its early stages. ${ }^{22}$ This criticism is a stretch, but there are legitimate concerns for those looking to protect the local culture of an ecotourism community.

Cultural impacts of tourism can be defined as "influences that come to bear upon the host society as result of tourist contact."23 These impacts can be both positive and negative. The host community that provides services for the tourism industry is often more in danger of destruction than the environment. The worst cases of cultural eradication through tourism are the result of a lack of planning by those who establish ecotourism in the country. Although the locals are in many ways the best and most informed source for understanding the local environment and how best to use it, their opinions are often 
overlooked or never sought. Lack of planning and local involvement often lead to large-scale tourism operations, where locals surround comparatively wealthy tourists ready to sell goods or provide various services. Because locals must compete for each tourist, they often mimic the visitors to their country in an attempt to cater to them. A separate culture from the native one slowly forms around tourism hotspots (e.g., popular beaches or parks). Large resorts attempt to create what operators believe is a tourist's paradise with fancy rooms, scenic hotel grounds, and high-dollar meals. Locals will often start speaking English, vendors start selling food or products popular in American or European markets, and the prices of goods skyrocket in comparison to surrounding communities. Tourism critic Deborah McLaren describes in her book Rethinking Tourism and Ecotravel how disappointed she was on her first trip to Jamaica. After a considerable search she was able to find an authentic reggae bar frequented by locals; but as soon as American tourists showed up, the deejay began to play Madonna and Michael Jackson. "The tourists," he explained, "like American music."24 Sometimes locals are actually forced to interact with visitors in the most appeasing manner possible. Mangers and owners of large resorts, for example, may require their staff to speak English to visitors.

This type of tourism creates a divide between visitors and their hosts. The locals only get to know visitors from a subservient role. They see visitors only as wealthy vacationers with a great amount of money to 
spend, not realizing that the "wealthy" Western tourist may be a middle class guy who lives month to month on his paycheck but has been saving for this trip for months or even years. Since locals only know their visitors from their subservient position, locals can begin to feel as if they are less than the visitors to their country. Because the price of living can rise dramatically in tourism hotspots, locals often cannot afford to frequent some of the more popular destinations in their own country. Locals can feel resentment because part of their community has been developed and is accessible only to foreigners. This is what McLaren calls the "paradox of tourism." In her words, tourism "must lure consumers away from home by implying that a tour is a rare chance to visit unique peoples and environments. But once tourists start invading, a version of the original culture of the destination is co-opted by the tourist industry and supplants the more complex, organic original." 25

Tourism also brings competition to people who frequently have never made their living in a competitive environment. Communities are sometimes pitted against other neighboring communities, causing polarization. Under the pressure to make money in this environment, some locals will resort to selling just about anything-including their history and culture. Eager to please their visitors, locals can often put on elaborate ceremonies or enact traditional religious rites that, before tourists arrived, were considered sacred and private. For example, in 
Hawaii, a major tourism market, there has been a loss of rich Polynesian culture because of tourism. Mention Hawaiian culture and many people conger up images of friendly women doing the hula in grass skirts and placing leis around the necks of tourists. But as some native Hawaiians have pointed out, the commonly thought of version of the hula actually encompasses a mix of various Polynesian cultures with added sexual connotations intended to appeal to visiting men. The power and sacred meanings of the hula have been lost only to be replaced with a cookiecutter, tourist version that some native Hawaiians find offensive. ${ }^{26}$ Tourism also can bring a number of social ills that become a great cost to the community, both economically and socially. Possibly the worst of these problems is sex tourism. It is understandable that tourists often want to relax and let their hair down while vacationing. Some tourists, however, take the concept of relaxing and vacationing from every-day responsibilities to an extreme by vacationing from any normal social constraints they would have back home. Some tourist destinations actually market the idea of escaping social constraints. Las Vegas' new ad slogan, for example, is "What Happens in Vegas, stays in Vegas." The city's new television ads feature people who have just engaged in or are planning to engage in behavior they would not normally. Because they are in Vegas, however, they are able to escape any long-term consequences for their behavior, which would usually be considered socially unacceptable. One of the funniest of these ads 
features a young man in his hotel room calling the front desk to schedule a wakeup call. "Can I get that call to my cell phone," he says. "You see, I don't know if I'll actually be in my hotel room."

Cities such as Las Vegas or Amsterdam in developed countries are often more than well equipped to deal with activities such as drug use, prostitution, or gambling. But countries in the developing world usually are not. If the locals find themselves dealing with visitors from a subservient position, even if it is only perceived to be so, they are highly susceptible to being exploited. One of the worst types of exploitation to grow out of the tourism industry is the exploitation of young women in the sex trade. A number of tourism hotspots in the developing world have had to deal with the consequences of the sex trade. Sex tourism is often more associated with mass tourism, but it has been a problem with ecotourism as well. The sex tourism trade is strong in many parts of the Caribbean. In Cuba, for example, where the sex trade has been on the rise, the Ministry of Tourism has recently taken steps to discourage visitors from visiting the island for sexual escapades. ${ }^{27}$ A study by ecotourism researchers in Belize found sex tourism and drug use were regularly engaged in by self-described ecotourists. The study also found that sex tourism was popular with both men and women, who were mainly white and looking for a sexual adventure with the native, "exotic" population. ${ }^{28}$ 
One of the worst hit areas of the world by the sex trade has been Southeast Asia, where young girls are trapped into a life of prostitution to serve tourists from all over the world. Women are enslaved at young ages by brothel owners, and sometimes family members, who will use debt and ostensible kindness more often than beatings to control their workers. In places like Cambodia and Thailand, as little as $\$ 8$ US can buy a visitor the company of a young lady and a room for the night. This type of exploitation is one of the worst forms of organized human rights violation in the world today, and it thrives in part because of tourism.

These negative cultural impacts of tourism do not necessarily have to happen, of course. One model for addressing sex trades has been provided by Costa Rica. The popular ecotourism destination has put together an aggressive plan to stamp out its sex trade. The government is now providing classes for ordinary Costa Ricans, from taxi drivers to hotel staff, on how to stop abuse of children through sex tourism. The government is also sending out thousands of workers in the tourism industry to spread the message for tourism operators not to help tourists find under-aged girls. Taxi drivers are exceptionally important to stopping the trade, since tourists often use them to find under-aged girls. This is all part of the tourism industry's Code of Conduct. ${ }^{29}$

Costa Rica's Code of Conduct is an example of the process of protecting the culture of an ecotourism community. The frequently occurring negative social impacts of tourism are avoidable, and in fact, 
local communities can actually benefit socially and culturally from ecotourism. In order for local communities to benefit, however, they need to play a large participatory role in establishing and maintaining the tourism process. Consideration for the culture of the local community should be incorporated into the planning and marketing of an ecotourism destination. Outsiders cannot accomplish this. As Sylvie Blangy and Megan Epler Wood recommend, local institutions such as tourism boards and national and local agencies should establish guidelines to ensure that tourists treat the local population with respect and as equals. These guidelines should provide education on issues that are particularly sensitive to negative impacts from tourism, including protection of local customs and traditions, appropriate dress, what language will be spoken, and proper responses to begging and overexcited sales people. ${ }^{30}$ The greater the role played by locals, the more culturally sustainable ecotourism will be.

Profits or Conservation: What is the Primary Objective? Answering this question is more difficult than answering what is ecotourism. I put the question, "What should be the top priority for any ecotourism program in Gabon?" to a number of experts on conservation, community development, and the Congo Basin. The answers I got back were as varied as the backgrounds of the people I asked. If you ask conservationists or scientists, they will generally tell you the primary objective of any ecotourism venture is to conserve and protect the 
environment. When I asked Dr. Lee White, his response was, "that ecotourism contributes to conservation." When I asked a professor and author of several articles on the political and social makeup of Gabon, I was told, "preserving the rainforest and benefiting the pygmies."

Your response to this question will greatly affect the type of ecotourism organizational structure you hope to create. There are a number of examples of ecotourism models created for the primary goal of economic development. In general, they are not very successful at protecting the environment and many should really not be considered ecotourism. Many of these popular "eco"-in-name-only tourist destinations can be found in the Caribbean and Central America. In Cancun for instance, a popular Spring Break hot spot, the Mexican government and private enterprise have invested heavily into turning the beach into a profitable commodity. The investment has workeddepending on how you look at it. Cancun has been transformed from a small fishing village with roughly 400 residents into one of the major tourism centers in the hemisphere, with more than 300,000 residents. Hardly anyone would dispute that Cancun has a strong nature-based appeal to its visitors. Very little if anything is done to minimize the environmental damage from tourism, however, and conservation is not a major concern in Cancun.

In the Caribbean, tourism is driven overwhelmingly by a desire to make a profit, and environmental concerns are given little attention, if 
any at all. Tourism is the main source of employment in the Caribbean, with tourism employment reaching as high as 20 percent on some islands. ${ }^{31}$ The Caribbean islands account for only 2.4 percent of the world's population, but as recently as 2000 accounted for 7 percent of all international stayovers. The islands are also the most popular destination in the world for cruise ships. ${ }^{32}$ The popularity of U.S.-based cruse ships has had an enormous role in causing the area's environmental damage. Caribbean cruise ships are big business, earning anywhere from $\$ 4$ to $\$ 6$ billion US a year. Even though they carry U.S. passengers, leave from U.S. ports, and advertise to a mainly U.S. audience, because they operate in international waters, they are largely unregulated. So in addition to avoiding taxes and labor regulations, they are also able to avoid environmental standards. ${ }^{33}$ The environmental damage created by mass tourism in the Caribbean has been severe; and despite governments and businesses embracing the rhetoric of ecotourism, they have yet to make a serious attempt to minimize the damage. The coral reefs of the Caribbean rank among the world's most endangered due to tourism, industrialization, shipping, and sedimentation. ${ }^{34}$ Most of the islands have experienced extreme levels of deforestation. The worst damage so far has taken place in Haiti, which retains only 1 percent of its original forest cover. The situation is also bleak in the Dominican Republic, which retains only 25 percent; Cuba, 29 percent; and Jamaica, 35 percent. ${ }^{35}$ 
On the other side of the equation is a different problem: Tourism with the primary objective of conservation often does not make a profit. Even areas that have been successful at achieving the goals of both conservation and profit find that it sometimes takes a while before you reach the latter. True environmentally friendly tourism relies heavily on good will from travelers willing to spend more for a genuine ecotourism experience. While ecotravel may well be on the rise, it still constitutes only a small portion of the tourism market. Even within the ecotourism sector, the percent of travelers who travel solely to view the natural environment is still fairly low. Most travelers are also interested in a novel cultural experience, seeing historical sites, and other traditional tourism activities.

Even those who are interested in only the nature-based aspect of a trip do not always pick the destinations that do a sufficient job of protecting the environment. Those tourists who are interested primarily in a nature-based tourism experience and actively seek out the most environmentally friendly tourist sites are very much the minority. ${ }^{36}$ True ecotourism also relies heavily on the good will of governments, especially in the Western world, and from private and nonprofit institutions. Over time, donations from these groups often dry up after the donors get bored with the same old cause. True ecotourism operations face a difficult dilemma. To best prevent any environmental damage caused by tourism, they must remain small. In order for small operations to make 
a profit, however, they must be willing to charge more than mass, largescale tourist operations. Because of their prices, they are out of the reach of many travelers and they run the risk of being viewed as elitist. The culmination of all these challenges regularly means that ecotourism operations are not sustainable. In fact, there have been some critics who have claimed that there no examples of profitable or sustainable ecotourism projects. ${ }^{37}$ While I am inclined to disagree that there are no examples of profitable ecotourism initiatives that adequately protect the environment, these critics do have a good point.

The answer to the profit-or-conservation dilemma was provided to me when I asked the district ranger of a National Forest in the Southeastern United States how ecotourism differs from other development models. "Ecotourism should differ from other developmental models," he said, "in that development of an ecotourism site or area will not have the primary goal or focus of returning a profit to the developer. It would be naïve to think there wouldn't be some developers that will be in it for the money, but the primary goal should be protection of the ecosystem so that ecotourists will keep coming back and the venture can produce revenue for the local community and the economy."

The importance of balancing the books should not be understated. Even nonprofits need to pull in more money then they spend to be sustainable. Whether ecotourism is able to at some point create a profit 
in Gabon will be a major test of whether Gabon's ecotourism aspirations succeed. But in order to truly protect the Gabonese rainforest, those looking to establish ecotourism need to have their priorities in the right order. Since ecotourism does have an altruistic component, the primary objective of any true ecotourism initiative should be conservation. A short-term focus on profits will usually lead to environmental degradation, consequently causing the ecotourism destination to lose its primary appeal to tourists, which is the unspoiled and beautiful natural environment. Long-term conservation is best achieved through education. This means education of tourists, but primarily of the local population on how to maintain programs and the significance of conserving the environment. Locals also need to be informed from the start that the primary goal of the ecotourism venture is conservation in order to avoid unrealistic expectations. If education is achieved, then sustainability will be less of a problem.

\section{Plugging Up Leaks}

In any international operation, the revenue from the venture must be split between at least two different countries: (1) the host country; and (2) the country supplying the necessary components for the venture, whether these components are labor, machinery, or whatever else. Unfortunately when a developing country is involved in such a deal, it is usually the one to receive the short end of the stick. For example, most of the revenue generated from mineral extraction operations in Gabon 
goes to benefit Western businesses and governments. The benefits for Gabon are nothing more than something of a finder's fee and, with some luck, a few jobs for locals. The dynamics are similar with ecotourism. Ecotourism requires a host country and different countries supplying the necessary components of tourism, e.g., materials to create buildings, food for tourists, and most importantly the tourists themselves.

One major concern for many ecotourism critics is that much of the cost of a trip remains with the country supplying the tourists. Airline travel is usually the most expensive part of an ecotourism experience. But other expenses can also prominently factor into the equation. For example, a travel agent may book the trip. If the visitor uses a U.S.based travel company that puts together trips, the company may supply its own operator or guide to lead the tour. Of course if it is a U.S.-based company organizing the trip, it often has marketing, staffing, and other expenses that it is going to pass along. Even money spent within the host country does not always entirely benefit the local population. If a visitor eats at a local restaurant, it does benefit the host country's economy. It benefits the local economy less, however, if the restaurant is forced to import all of its food; and it benefits the economy even less if the restaurant is owned by a foreign company or individual. This occurrence of money directly or indirectly flowing away from the host country is known by tourism experts as leakage. 
Some ecotourism host countries do a better job than others of making sure that revenue generated from ecotourism says in their country. Studies indicate that in most developing countries the majority of money spent on tourism leaks away to pay for imported goods and services used in the tourism industry. In the average developing country, more than half, roughly 55 percent, of money spent on tourismrelated expenses leaks out of the country. The average for Caribbean countries is 70 percent. In communities close to nature tourism sites (e.g., national parks), it is estimated that more than 90 percent of spending leaks away. ${ }^{38}$

Tourism leakage is a difficult problem to solve, especially since the causes of leakage often have nothing directly to do with tourism. The reason why developing countries have higher levels of leakage is they simply have fewer homegrown goods and services to offer tourists. ${ }^{39}$ Usually outside forces will fill the void for wanted or needed goods and services because this is easier than developing the local capacity to produce them. Another problem that contributes to tourism leakage is rapid tourism-related development. It is hard for local investors to keep up with rapid development, triggering foreign investors to jump forward.

One approach to combating tourism leakage is to merely stay smaller. Conventional wisdom and studies on the issue show that smallscale tourism development involves less leakage than large-scale tourism. ${ }^{40}$ Aside from staying small, there is really no way to combat 
tourism leakage that is directly related to developing tourism. Allowing more funds to stay within the host country requires investment in local and village-level development so that locals can produce goods such as food to be sold in restaurants or grocery stores; materials to create buildings or even something like a river taxi; and even produce people to function in roles such as tour guides or business managers in order for locals to manage the system. Obviously, explaining how to stimulate this type of Third World development requires a thesis unto itself. But discussions and analysis of programs that have experienced some success with village-level development can be found in chapter 5 .

\section{Withstanding the Unpredictable}

One common theme that runs though all tourism ventures is that they are predictably unpredictable. Tourism is an industry that experiences cycles of ups and downs, but some of the causes of these ups and downs are difficult to foretell, especially with regard to environmental tourism. Natural disasters are a major outside force that can influence the ecotourism market. Obviously the ecotourism industries in Thailand, Indonesia, and other islands in the Indian Ocean were greatly affected by the tsunami of 2004. Rebuilding the tourism infrastructure in that part of the world will take some time. The hurricanes in the Gulf of Mexico and Caribbean in 2004 adversely affected the tourism markets in Florida and some Caribbean islands. Media coverage of political strife or diseases such as AIDS can turnoff 
potential tourists. Increased coverage of the Nepalese government's ongoing trouble with Maoists rebels has negatively affected the ecotourism industry so much that the country's tourism board and national airline have been actively trying to reassure tourists that they are in no danger when visiting. ${ }^{41}$ Even pop culture in the global North can affect Third World Tourism. Ecotourism to Kenya rose dramatically after the release of the movie Out of Africa in the late 1980s. ${ }^{42}$ War also adversely affects the tourism market, even when the tourist destinations are not doing the fighting. While doing research for WildLaw's Gabon ecotour, I came across a nonprofit with a similar ecotourism initiative in Zambia. When I spoke to the executive director of the organization, she told me that the group's Zambia ecotourism program had experienced a sharp decline to the point of basically being nonexistent after the United States' global war on terrorism. "Since September 11, people have become more afraid of places like the Middle East and Africa," she said. "They believe that people in those parts of the world want to hurt them."

Some researchers argue that over the long term tourism is a more dependable form of development than other foreign exchange earners. Ceballos-Lascuráin, for example, contends that, compared with other industries, tourism seldom falls into a serious long-term decline, making the industry almost "recession-proof." This may be true. And a country such as Australia, which has a large ecotourism industry that is not, however, the country's primary source of national revenue, can easily 
withstand a drop in tourism. But what he fails to point out, as Martha Honey mentions, is that many Third World economies do not have the cushion to endure a shortfall of even a year or two. ${ }^{43}$ The lesson to be learned: No country should put all of its eggs in its ecotourism basket. 
Notes

${ }^{1}$ Martha Honey, Ecotourism and Sustainable Development: Who Owns Paradise? (Washington, D.C.: Island Press, 1999), 4.

2 Ron Chepesiuk, “The Ecotourism Explorer," Environmental Health Perspective 108, no. 5 (May 2000): A2 11.

3 World Tourism Organization, "Ecotourism, now one-fifth of market," World Tourism Organization News 1 no. 6 (1998).

4 Martha Honey, "Giving a Grade to Costa Rica's Green Tourism," NACLA Report on the Americas 36, no. 6 (1 May 2003): 39 - 46.

5 Richard Hammond, "The Better travel guide," The Observer, 28 March 2004, 2; and Charles Starmer-Smith, "Eco-friendly tourism on the rise," The Daily Telegraph, 6 November 2004, 4.

6 Martha Honey, Ecotourism and Sustainable Development, 8.

7 R.K. Blamey, "Principles of Ecotourism," in The Encyclopedia of Ecotourism, ed. David B. Weaver (London: CABI Publishing, 2000), 5.

8 Martha Honey, "Giving a Grade to Costa Rica's Green Tourism.”

9 R.K. Blamey, "Principles of Ecotourism," 5.

10 Ibid., $5-6$.

11 Paul F. J. Eagles, "Understanding the Market for Sustainable Tourism," in Linking tourism, the environment, and sustainability: Topical volume of compiled papers from a special session of annual meeting of the National Recreation and Park Association, ed. Stephen F. McCool and Alan E. Watson (Minneapolis, MN: Recreation and Park Association, 12-14 October 1994), 95.

12 Martha Honey, Ecotourism and Sustainable Development, 6.

13 "What is Ecotourism?" The Ecotourism Society, 2003, www.ecotourism.org/index2.php?what-is-ecotourism (accessed 31 March 2005).

14 R.K. Blamey, "Principles of Ecotourism," 6.

15 Ibid. 
16 "Québec Declaration On Ecotourism," World Tourism Organization, 1922 May 2002, http://www.world-

tourism.org/sustainable/IYE/quebec/anglais/declaration.html (accessed 25 January 2005).

17 Beatrice Blake and Anne Becher, The New Key To Costa Rica, 17 th ed. (Berkeley, CA: Ulysses, 2002), $32-33$.

18 Ralf Buckley, Case Studies in Ecotourism (Cambridge, MA: CABI Publishing, 2003), 1.

19 R.K. Blamey, "Principles of Ecotourism," 6.

20 Mark B. Orams, "Types of Ecotourism," in The Encyclopedia of Ecotourism, ed. David B. Weaver (London: CABI Publishing, 2000), 29.

21 Peter Murphy, Tourism: A Community Approach (London: Methuen, 1985).

22 Stephen Wearing, "Exploring Socio-cultural Impacts on Local Communities," in The Encyclopedia of Ecotourism, ed. David B. Weaver (London: CABI Publishing, 2000), 395.

23 Ibid., 397.

24 Deborah McLaren, Rethinking Tourism and Ecotravel: The Paving of Paradise and What You Can Do to Stop It, (West Hartford, CT: Kumarian Press, 1998), 2.

25 Ibid., 46

26 Ibid., 57.

27 Martha Honey, Ecotourism and Sustainable Development, 213.

28 Rosaleen Duffy. A Trip Too Far: Ecotourism, Politics, \& Exploitation (Sterling, VA: Earthscan, 2002), 34.

29 Philip Wright, "Sex Tourism: Lessons Learned in Costa Rica," BBC News, 20 June 2004.

30 Stephen Weaver, "Exploring Socio-cultural Impacts on Local Communities," 405.

31 Martha Honey, Ecotourism and Sustainable Development, 39. 
32 Robert E. Wood, "Caribbean cruise tourism: globalization at sea." Annals of Tourism Research 27 (2000) 345-370; and David B. Weaver and Regina Schlüter, "Latin America and the Caribbean," in The Encyclopedia Ecotourism, ed. David B. Weaver (London: CABI Publish, 2000), 173.

33 Martha Honey, Ecotourism and Sustainable Development, 39.

34 David B. Weaver and Regina Schlüter, "Latin America and the Caaribbean," 176.

35 Ibid.

${ }^{36}$ R.K. Blamey, "Principles of Ecotourism," 19.

37 Deborah McLaren, Rethinking Tourism and Ecotravel, 101.

38 Kreg Lindberg, "Economic Impacts," in The Encyclopedia of Ecotourism, ed. David B. Weaver (London: CABI Publishing, 2000), 367.

39 Ibid., 368.

40 Ibid.

${ }^{41}$ Malika Browne and Jan McGirk, "Welcome to the kingdom ruled by fear: Tourists are still beating a path to Nepal as its bloody civil war," The Independent, 23 August 2004; and "No hardship to tourists in Nepal: official," PeaceJournalism.com, 5 February 2005, http:/ / peacejournalism.com/ReadArticle.asp?ArticleID=1138 (accessed 31 March 2005).

42 Martha Honey, Ecotourism and Sustainable Development, 91. ${ }^{43}$ Ibid. 


\section{CHAPTER III}

\section{GETTING TO KNOW GABON}

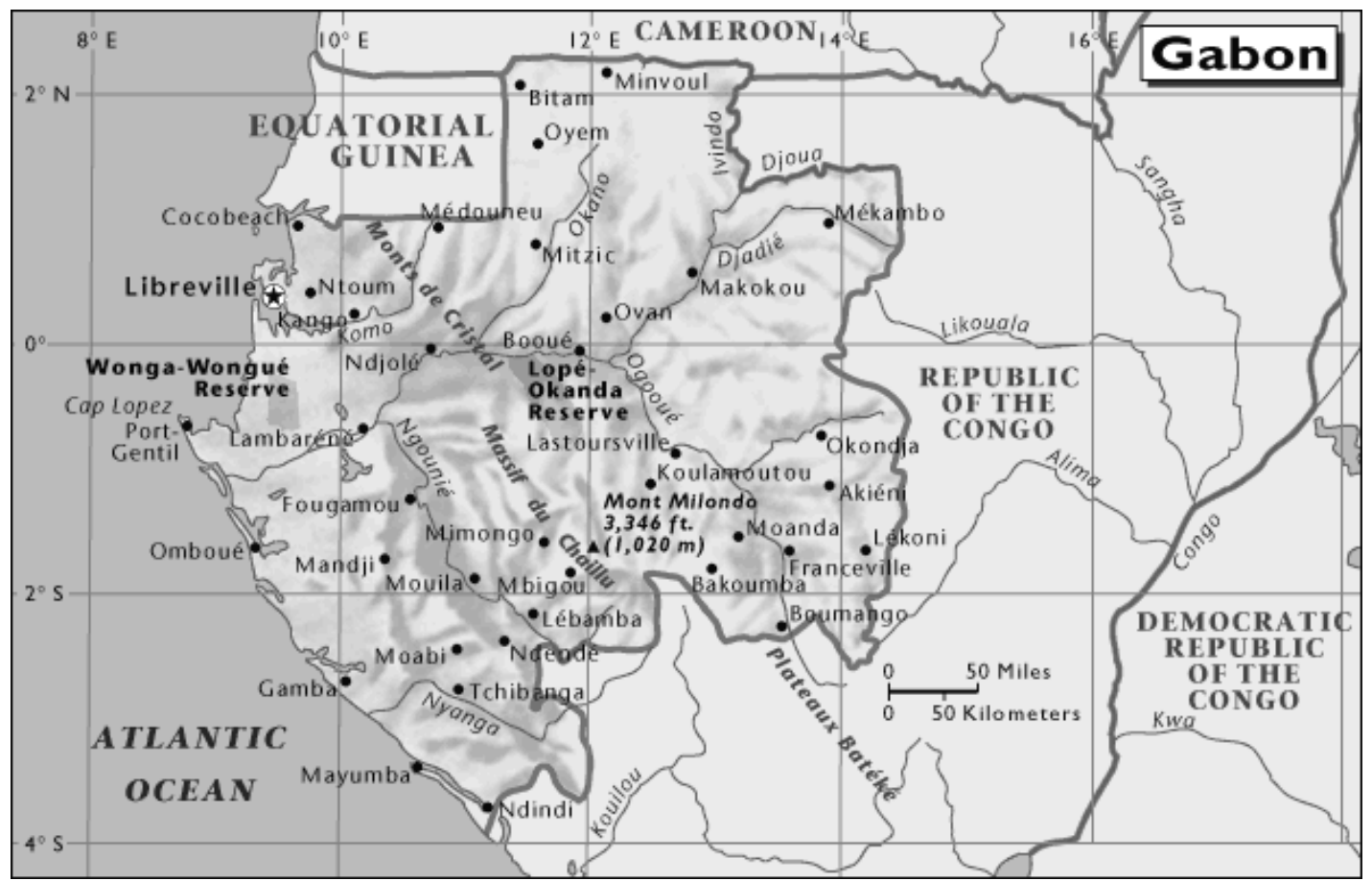

Figure 1. Gabon map adapted from Mapquest

The words ecotourism and Gabon may have never been used in the same sentence if it were not for the work of ecologist and explorer Michael Fay, who took on the daunting task of walking through most of the Republic of the Congo and all of Gabon, finishing on the Atlantic coast. Fay's trek, started on September 20, 1999, took him through parts of the Congo Basin rainforest that are believed to have never been seen by human beings before. Fay stated that his objective was to "go as 
deep and far from human species as possible" in order to witness one of the last pristine ecosystems on Earth, all with the intent of providing information that would aid efforts to protect Gabon's rainforest from threats such as population growth, increasing logging concessions, and a growing bushmeat trade. ${ }^{1}$ Fay's hike, co-sponsored by National Geographic magazine, which did a three-part series on the adventure, and the Wildlife Conservation Society (WCS), earned him international recognition as equatorial Africa's Lewis and Clark. He emerged from his adventure with 39 notebooks filled with data on the astonishing plant and wildlife diversity of Gabon.

What Fay documented on his trip was an environmental treasure like no other left on Earth. Gabon remains a last refuge for gorillas, giant canopy trees, orchids, and literally thousands of different types of insects, reptiles, and amphibians. On a whole, roughly 70 percent of Gabon remains covered in forests, which total between 17 to 21 million hectares. They are also among the richest and most diverse on Earth. Roughly 20 percent of the country's plant species are found nowhere else in the world. Surveys by the WCS estimate that there are more than 61,000 forest elephants in Gabon, the largest elephant population in Africa. One of the most noteworthy places Fay studied was an area called Langoué Bai (bai is Pygmy for forest clearing). Langoué Bai, which lies adjacent to the stunning Kongué waterfalls, is a part of the Earth 
that is almost unknown to humans. It is a refuge to large-tusked elephants and chimpanzees. But Fay's most exciting discovery in Langoué Bai was the existence of hundreds of "naïve gorillas," which have never seen humans before. These gorillas, unlike most gorillas in the wild, showed absolutely no fear of human beings. Unfortunately, more than 90 percent of Langoué Bai was scheduled to be logged. ${ }^{2}$

Another discovery of remarkable diversity on Fay's trip was an area called the Gamba Complex. The 6,838-square-kilometer area is an assortment of lagoons, lakes, and beach shores that until recently were unknown to scientists. In addition to its varied ecosystem, Gamba is home to a wide range of species, including forest elephants, forest buffalos, gorillas, leopards, giant canopy tree frogs, chimpanzees, and hippopotami. From the coast of the complex, one can see the humpback whales that swim in the Gulf of Guinea. In 2003, a team of more than 40 scientists from the Smithsonian Institute finished more than a year's worth of work trying to document all the plant and animal species that inhabit this region. Herpetologists discovered that the Gamba Complex contains as many as 159 species of reptiles and amphibians, as many as have been found in all of Gabon. Fish experts found more than 70 different types of freshwater fish. In one single week's worth of work studying a 26-square-kilometer area, botanists identified roughly 140 tree species, three of which grow nowhere else in the world. ${ }^{3}$ The 
government has given strong consideration to opening the Gamba Complex to logging as well, and commercial loggers are already operating nearby.

Luckily, President Omar Bongo took action to protect Gabon's most ecologically valuable areas before it was too late. Repeated lobbing by conservation organizations such as WCS and the World Wildlife Fund (WWF) paid off in August of 2002, when Bongo decided to protect a large section of the country's rainforests for ecotourism. The findings from Fay's expedition were a major factor in convincing Bongo to push for ecotourism development. Bongo took the unprecedented step of setting aside 11 percent of Gabon's landmass to create a new national park system. The conservation plan approved by Bongo created 13 new national parks, which will protect more than 16,000 -square kilometers of important habitats for gorillas, elephants, and other wildlife. Only Costa Rica has set aside a larger percentage of its land for conservation. ${ }^{4}$ The total size of Costa Rica's protected areas, however, is much smaller. To truly understand how risky and significant Gabon's ecotourism initiative is, one would need to understand the current state of the country and the challenges it was already facing.

\section{Gabon's Population}

Gabon has one of the highest GDPs per capita in Africa, but there has been very little academic study of the country's political, economic, 
or cultural climates compared to other African countries. ${ }^{5}$ One reason for the lack of study could be the country's small population. Despite its size, 267,667-square kilometers, or roughly the size of Colorado, Gabon has a population of only about 1.2 million people according to the World Bank, which at 4 people per square kilometer is the smallest population density in Central Africa. ${ }^{6}$ In 1960, Gabon's population, currently the second smallest in Africa, was estimated at 485,000. Using a growth rate estimate of 0.9 percent per annum, the World Bank placed the country's population at 680,000 in 1995 . The country's population is overwhelmingly Christian, predominately Roman Catholic, with a small Muslim population making up less than 1 percent. There are some 40 different ethnic groups, of which the Fang is the largest (comprising 40 percent of the population).

\section{The Economic Conundrum}

Gabon has built its economic success almost entirely on oil revenues. Prior to its transformation into a major oil-producing state, which took place after the discovery of oil offshore in 1948, at the same time that manganese and uranium was also discovered, Gabon mainly relied on timber revenue. Within a relatively short time, oil became the country's main export. Triggered by a spike in world prices, oil exploration and production hit an all-time high in the $1970 \mathrm{~s} .{ }^{7}$ To date, it remains the third-leading oil producer in sub-Saharan Africa, behind 
Nigeria and Angola. While the country's oil production and increased GDP contributed to its status as one of the wealthiest countries in Africa, Gabon still essentially remained a renter state, with concessions for exploration divided between French, British, and American companies.

Oil accounts for 80 percent of the country's exports, but it appears that almost five decades of total reliance upon the country's oil revenues has caught up to Gabon. For the first time in three decades, Gabon is now facing its revenue from oil being smaller than non-oil revenue because of dwindling reserves and ageing fields. The country must now confront a sharp decline in oil production, roughly 50 percent over the next five years. These declines have put further strain on the government's spending in a country where debt levels are already high. The International Monetary Fund (IMF) has warned the government that interest on repayments of debt could reach around 40 percent of state income within the next five years if the country's more than $\$ 3$ billion US debt continues to balloon. The drop in oil production has already contributed to a dip in the standard of living in Gabon. Current World Bank estimates place the country's per capita GDP at $\$ 3,300$ US annually. While still better than most African countries, this is a drop from the per capita GDP in excess of $\$ 5,000$ US the country was experiencing at the height of its oil boom. ${ }^{8}$ Since 1997, oil production has fallen from 370,000 barrels a day to fewer than 250,000 today. It is 
predicted that the country's production will fall to about 130,000 by 2010. The government has been somewhat able to offset the loss of revenue from falling production because of the current high price of oil. When oil prices begin to fall, however, Gabon is likely to truly feel the economic consequences of the falling production levels. ${ }^{9}$

Falling production levels mixed with Gabonese xenophobia toward its African neighbors has also led to escalated conflict between Gabon and its smaller neighbor to its north, Equatorial Guinea. Gabon's falling production levels have come at the same time that Equatorial Guinea has experienced an increase in production, causing it to pass Gabon as the major oil producer in the region. Despite its much smaller size, Equatorial Guinea controls a much larger maritime territory than Gabon. Currently the two countries are engaged in a dispute over who should control Corisco Bay, which is believed to have large, untapped reserves. While there has been quiet disagreement over who has claim to the islands in the bay since 1972, Gabon's drop in production levels has added to the country's sense of urgency to resolve the conflict by whatever means necessary. Disagreement over the islands has prevented full exploration of their reserves since the 1970s. Eager to quickly gain claim to the islands, Gabon's Defense Minister, Ali Bongo, son of President Bongo, visited the islands in February 2003 to reassert the country's territorial claim. ${ }^{10}$ 
As one can imagine, Equatorial Guinea's response was swift and angry. Equatorial Guinea's prime minister denounced “Gabon's illegal occupation" of the islands on state-run radio. The African Union and the United Nations have since intervened to try and resolve the long-running dispute. Eager to find non-Middle Eastern sources of oil, the United States has also expressed interest in resolving the dispute quickly. Both countries agreed to let U.N. mediators settle the issue, ${ }^{11}$ and on July 6 , 2004, U.N. led talks culminated in a tentative framework agreement. ${ }^{2}$

\section{Alternative Sources of Income}

The dwindling oil reserves and ageing fields have forced the government to turn to alternative sources of income. One possible alternative is manganese. Increased exploration of manganese reserves is an option under serious consideration in Libreville. Gabon has some of the largest concentrations of manganese in the world; and unlike its oil reserves, the country's manganese reserves are not likely to run out any time soon. It is estimated that the current levels of exploration can be supported for the next 150 years. World demand for manganese, however, has been erratic, ranging from a high of 2.3 million tons that were exported in 1979 to only 1.4 million three years later. ${ }^{13}$ At best, Libreville can only realistically hope for its manganese reserves to offset a small amount of Gabon's lost oil revenue. 
With no chance of the country's other mineral exports completely offsetting the loss in oil production, the government has seen little alternative other than turning to commercial logging. No issue poses a greater threat to Gabon's environment than logging. Besides the obvious effects of cutting down trees, logging also opens up more roads for poachers and increases the bushmeat trade, which is said to be worth more than $\$ 50$ million US annually in Gabon. ${ }^{14}$

At one time, logging was Gabon's largest industry. In fact, so powerful was the French-controlled timber industry that its leaders played a prominent role in creating Gabon's post-colonial government. As recently as 1960, timber still accounted for roughly half of Gabon's national budget. In the 1970 s, increased exploration of the nation's mineral resources, mostly oil, drastically reduced the role the timber industry played in the national economy. Today, timber accounts for less than 10 percent of exports, ${ }^{15}$ and makes up 4 percent of the country's GDP. ${ }^{16}$ While the timber industry has declined in importance, however, it is still the country's second largest source of revenue, employing more than a quarter of the working population. ${ }^{17}$ Initially logging activities were concentrated along Gabon's coast, where trees were easier to access and transfer. Over time, logging companies have moved farther into the country's interior. Throughout the 1990s, timber 
production drastically increased to the point where half of Gabon's forest is now leased to loggers. ${ }^{18}$

It is hard to get many specifics about who is logging Gabon's timber. As a study by the World Resource Institute put it: "There is a lack of transparent information on logging companies."19 Logging companies are technically required to register with the government, but many larger European companies establish small, Gabonese subsidiaries as fronts. We do know that recently as 1997, Gabon's logging concessions were held between 221 different companies, most of them European. Of these companies, 13 held logging rights to 50 percent of all of Gabon's concession areas-or 21 percent of Gabon's total forest cover. ${ }^{20}$ Logging companies in the region also have a bad habit of exceeding their quotas. Neighboring Cameroon's forests are facing near annihilation in large part because of quota busting by logging companies. Studies have shown that in 2004 , a record 49 of the 90 companies that officially hold permits to log in Cameroon were sanctioned for exceeding their quotas. ${ }^{21}$

Most companies are attracted to Gabon's Okoumé trees, found only in Gabon, Equatorial Guinea, and parts of the Congo. Okoumé timber is highly valued on the world market because it makes excellent plywood. It accounts for 73 percent of the Gabon's timber exports. At one time it was believed that Okoumé grew comparatively quickly. More 
recent evidence, however, suggest that the tree's growth rate is much slower than previously thought. ${ }^{22}$ The majority of wood logged in Gabon is exported to either Europe or Asia.

In Gabon, the government is the major landowner and grants permits to companies to log. While the government's forestry policy officially states its goals are to produce more sustainable forestry practices, there are a number of problems with the concept of sustainable forestry in Gabon. Even when loggers cut down only one tree, it creates considerable damage to the forest canopy. Aside from any theoretical critiques of the concept of sustainable forestry, however, there are also problems with the country's policy. Some of these problems are a lack of personnel to enforce compliance with the law and undefined standards for loggers to follow. One major problem is the practice of fermage, or subleasing logging rights to a third party in exchange for a fee. While the practice is widely known to be illegal, it continues nonetheless. Fermage causes more environmental damage than normal logging concessions because the original permit owners receive large rents without feeling responsible for investigating logging practices. Similarly, logging companies feel no need to practice sustainable logging because they have no vested, long-term interest in the land. ${ }^{23}$

Libreville has already committed itself to more logging concessions, pinning much of its hopes of staving off a major recession on expanding 
the timber sector's contribution to the national economy. But despite the current economic pressure to expand the timber industry, President Bongo has decided to slow the increase of timber concessions in order to develop the infrastructure for ecotourism. Those seeking to develop ecotourism in Gabon, however, will face a great number of problems. Many of these challenges are tied to the country's history and recent emergence from a difficult colonial rule.

\section{Gabon's Colonial History}

Examining Gabon's colonial history and its aftermath provides answers as to why post-colonial development as been difficult. Described by one author as a "Neo-Colonial Enclave of Enduring French Interest," 24 Gabon is still suffering from the effects of a long, harsh colonial rule. The earliest settlers to Gabon were probably the Pygmies, who lived in small groups along the riverbanks long before Europeans stepped foot on what is today known as Gabon. The pygmies number only several thousand today and are in the most remote parts of the country. They were first displaced in the sixteenth and seventeenth centuries by Fang tribes, who were migrating from what is now Cameroon and Equatorial Guinea. The first Europeans to Gabon were the Portuguese, who arrived in 1472. They largely ignored the area; however, the British, Dutch, and French used the country's coast to trade for slaves, ivory, and wood. 
Libreville, Gabon's capital, was established in 1849 by freed slaves. The word Libreville actually means "free town."

The French arrived on the coast of Gabon in the 1840s. They used bases in Gabon to enlarge their claims to the Congo Basin by penetrating farther into the Congo and making treaties with various indigenous groups. In a series of expeditions between 1875 and 1882, French naval officer Pierre Savorgnan de Brazza explored the region between the Ogooué and Congo rivers. Eventually French expansion moved far enough east to reach modern-day Brazzaville. An 1888 decree by the French parliament united all of the France's territories in the Congo into one single region to be known as the French Congo. ${ }^{25}$ From 1886 to 1904, Libreville was designated the capital of this region.

Up until the 1880s, European expansion into tropical West Africa was hardly noticeable. This changed as a result of European investigations into the region in the 1870 s, which created interest in the area's abundant resources. Interest in colonizing the Congo Basin did not originate with the French, but with Belgium's King Leopold II. Leopold believed that the application of European capital and skills to natural resources in the area would be highly profitable. In 1876, he called an international conference at Brussels to create the African International Association to raise money for further exploration into the region. After Belgium successfully began establishing colonies in parts of 
the Congo Basin, the French, British, and Portuguese began to get nervous about protecting their interests in the region. This crisis in the Congo was one of the major factors that led to the Berlin Conference of 1884, which was the genesis for the political fragmentation of Africa. ${ }^{26}$ France was one of the major players of the Berlin Conference, which include 13 other European countries plus Russia, Turkey, and the United States. Before the conference, only Africa's coastal areas were colonized by Europe. During the four-month conference, European powers scrambled to each lay claim to their own section of Africa without regard for the cultural and linguistic differences between the continent's many different indigenous people. One of the many outcomes of the conference was the division of the Congo Basin between the French and the Belgians. Belgium and King Leopold II took control of the Democratic Republic of the Congo, what later became Zaire. France took over Gabon and the Republic of Congo in addition to much of West Africa. Under Leopold's rule, more than half of the Belgian Congo's population died.

Gabon also suffered as a result of the further French exploration after the conference. Increasingly more French troops and administrators as well as European businessmen and missionaries had moved deep into the interior of Gabon by river. ${ }^{27}$ By the early 1900s, the French were establishing mission schools where they trained the Gabonese elite, which led to the disappearance of native languages. 
Shortly after this colonial invasion, the indigenous cultures of the country's small rural population were virtually wiped out. The Gabonese were subjected to forced labor, villages being uprooted, the destruction of native religious groups, diseases, and the rise of prostitution. ${ }^{28}$ The French used forced laborers to grow cash crops such as coffee and cocoa causing famine and disease as staple crops suffered. As time passed, French Equatorial Africa was divided into different zones controlled by various French companies. Gabon was split between 11 different companies that were given the rights to plunder their territories' natural resources and the power of life and death over the indigenous people. Tens of thousands of native people fled to the Ngounie and Ogooué valleys to avoid the brutalities of French rule in interior Gabon. Population levels in these areas remained static for the next 30 years. ${ }^{29}$ Travel in rural Gabon today and it is practically impossible to find any culture that has not been heavily influenced by the French.

Gabon's Pseudo Independence

After World War II, France began the slow process of decolonization in francophone Africa. In 1960, all of France's African colonies, including Gabon, were granted independence. Since its independence, Gabon has had only two presidents. The first of these was Léon M'Ba, founder of the comité mixte gabonais (Committee of Mixed Gabonese), a pro-French political group primarily comprised of ethnic Fang, the 
largest ethnic group in Gabon. M’Ba, a Fang himself, was a Francophile and strong supporter of Charles de Gaulle. ${ }^{30} \mathrm{M}$ 'Ba was also a favorite of the French forestry industry, which helped choose and groom him for the office of the presidency. ${ }^{31}$ Prior to the country's independence, M'Ba had moved up Gabon's political ladder with French support. In 1956, he was elected mayor of Libreville and in 1958 became president of the country's pre-independence government council. M'Ba advocated remaining close to France-even at the expense of independence. In 1958, the Gabonese voted on a referendum to become part of the French Community, an organization of French colonies similar to the British Common Wealth. M'Ba was the lead advocate in favor of community membership. The referendum overwhelmingly passed with M'Ba as head of the new coalition government. On August 13, 1960, Gabon became an independent republic with $\mathrm{M}^{\mathrm{B}} \mathrm{Ba}$ as its first president. The next year, he was elected to the post.

As president, M'Ba served to protect France's interests in Gabon. He advanced the myth started by the French that they had a benevolent entry into Gabon and that the Gabonese freely accepted French rule. M'Ba claimed that the "Gabonese people were never conquered because the tutorship exercised by the French was the result of agreements freely entered into with her beginning in 1893." He pled for the Gabonese to "love" and be "hospitable" with the Frenchman because "he makes people 
rich."32 M'Ba's argument was a lie of course. The majority of Gabonese were opposed to French presence in Gabon. As early as 1862, opposition to the French was growing in parts of Gabon's coast, leading to revolts in the 1870s. In interior Gabon, tribes also resisted the French occupation that followed de Brazza's explorations. Most tribes only ceded land under pressure or after a continued French bombardment of the area. Some did freely enter into treaties of dependency, but did not realize that physical domination would be involved. ${ }^{33}$

In 1963, M’Ba dropped his Minister of Foreign Affairs for refusing to support the formation of a single-party government and dissolved parliament to order new elections. This prompted several Gabonese military officers to overthrow M'Ba in a bloodless coup in February 1964. Although the Gabonese supported the removal of M'Ba and there was no plea for assistance, the French military swiftly acted to return M'Ba to power. France could argue it acted to protect the democratic process, but there is little doubt that France was also interested in protecting its investments in uranium, petroleum, manganese, iron, and timber. ${ }^{34}$ After the coup, M'Ba's government was more repressive than ever. In 1966, M'Ba was diagnosed with cancer, and the French soon found themselves searching for his replacement. 
Bongo's Continuation of French Influence

In November 1966, the Vice President of Gabon was replaced by M'Ba's close confidant Albert-Bernard Bongo. Bongo was active in Gabon's French colonial government, serving two years as a second lieutenant in the French Air Force. He was also a veteran of Gabon's post-independence government, serving in a number of governmental positions, including in M'Ba's cabinet. In February 1967, Gabon's constitution was amended so that the vice president would automatically succeed the president in the event that the latter was unable to serve. In November 1967, M’Ba died and Bongo ascended to the office of president. He has held the position ever since.

With the death of President Ganssingbe Eyadema of Togo on February 5, 2005, Bongo became the longest ruling head of state in Africa. More than three decades of autocratic rule, along with Gabon's abundance of natural resources, have made Bongo one of the world's richest people. Bongo, who changed his name to Omar Bongo in 1973 after converting to Islam, was groomed for the position of president as soon as M'Ba's illness was discovered. Although Bongo is Batkéké, a small and rather inconsequential ethnic group in Gabon, he came not coincidently from a region in the southeast where large deposits of strategic uranium and manganese are found. ${ }^{35}$ Attempts to examine Bongo's regime have labeled him an "African autocrat" and a "non- 
ideological pragmatist" practicing neo-colonialism. ${ }^{36}$ Bongo does profess to having no ideology but denies that he has ever served to protect French interests. Nonetheless, since Bongo has taken over, the French military has intervened twice to prevent the overthrow of his government.

During most of Bongo's rule, Gabon's stability has been solidly based on the assurance of the French military. ${ }^{37}$ France still has permanently stationed troops near Libreville that serve as a warning to rebel groups looking to overthrow the government, but it remains unclear if France is still willing to use military intervention to protect Bongo. French political leaders have at times talked out of both sides of their mouths, stating openly that France does not want to get militarily involved with Gabon but also using threats of intervention to quell uprisings. In 1990, French President Francois Mitterand explicitly rejected any military intervention to protect regimes that are threatened internally. Yet, in a number of subsequent instances, France has intervened in such situations in its former colonies, including Gabon. ${ }^{38}$ In May of 1990, the largest anti-government demonstrations in the Gabon's history broke out in Port Gentil, one of Gabon's main economic centers, after the mysterious death of an opposition leader Joseph Rendjambé. ${ }^{*}$

\footnotetext{
* It is not entirely clear whether Rendjambé was murdered or died of natural causes. His followers contend that he was murdered by a lethal injection administered by a woman hired by Bongo. The government
} 
France flew troops into the area to restore order. According to the French government, the action was only to protect its expatriates. Yet Mitterand's government also found itself confronted with institutional arrangements dating back to de Gaulle. Rioting had for the first time in history stopped the production of oil, and French companies were losing millions each day that the pumps were off. It was in this context that the French military intervened. ${ }^{39}$ In addition to the French troops, France also publicly informed Bongo that it had no wishes to get involved with the country's affairs, exonerating Bongo's use of his own mercenary forces. ${ }^{40}$ Either directly or indirectly, France's military maintains a role in helping pro-French regimes remain in office. ${ }^{41}$

In addition to the past guarantees of French military intervention, Bongo's reign was also due in large part to the country's rigid singleparty political system. ${ }^{42}$ Bongo instituted this system shortly after he took office by blaming the popular dissatisfaction with M'ba's government on the multi-party system and the "tribalism it engendered." 43 Political protests in the early 1990s were able to force Bongo to accept some reforms and organize multiparty elections. Gabon's 1993 presidential election was a test of Bongo's rule. Prior to the election, there had been popular opposition to Bongo. An abundance of political parties were formed, and several had national appeal. Both Bongo and his opponents

report of his death states that he died of "natural causes," and that the syringe marks on his stomach were the result of diabetes. 
campaigned hard across the country. Bongo, however, had several advantages. The opposition lacked the human and financial resources that he was able to mobilize. He also had a smart political strategy of using state finances to undermine his strongest opponents and keep his weaker ones afloat. ${ }^{44}$ Still the opposition was optimistic that the elections would bring an end to Bongo's rule. Prior to the election, safeguards had been put into place to ensure a transparent election. Each candidate was given media access to present a platform. An electoral commission with members from the opposition and the incumbent majority was formed to count the votes. Even so, Bongo created a catch. All electoral documents and procedures had to be validated by the Interior Ministry, which was headed by Bongo loyalist Antoine Mboumboou Miyakou. Early results after the election showed that the opposition was on the way to a large victory. The commission had not yet counted all of the votes from Libreville, however, when it was announced by Miyakou that Bongo had been reelected with 51 percent of the vote. 45 The election results provoked an immediate outrage. The Governor of Estuaire Providence, which has jurisdiction over Libreville, resigned in protest of the outcome. International NGOs issued statements criticizing the election. Protests and riots broke out across Gabon, as the country came to a virtual standstill. Bongo was able to 
restore order using a mixture of negations and his presidential guard to stomp out opposition. 46

It is doubtful that Bongo will be vacating the presidency any time soon. Even if he were to leave office, however, it would not mean the end of French influence in Gabon. France provides legitimacy for its former colonies, and both incumbents and their opponents in former French colonies take this into account. France has also developed a dependence on raw materials from Gabon, mainly oil and timber. Bongo understands how to use the French-Gabonese relationship to his advantage. On occasions, France has stated that French aid is reserved for democratic countries. Gabon has been able to avoid such stated conditions, however, because Bongo has fulfilled France's economic interests in Gabon. ${ }^{47}$ For the foreseeable future, Bongo will continue to hold the country's wealth hostage while taking most of his political cues from Paris. ${ }^{48}$

The Residue of Colonialism

Gabon's post-colonial identity is inseparable from that of France. In the years immediately following Gabon's independence, the French presence and influence in society actually increased because the country experienced an extraordinary economic boom due to revenues from petroleum and mineral exports. As with other colonies throughout Africa, colonialism produced a highly fragmented society. Unlike many 
African colonies, however, the lines of division within Gabon were not drawn between ethnic groups. Instead, post-colonial Gabon was divided along lines of nationalism, between those who were Gabonese by birth and those who were outsiders.

Much of the nationalistic xenophobia within Gabon, which has frequently led to violence, is directly linked to the oil booms that created Gabon's image as a wealthy African country. The oil industry in Gabon has always exacerbated a pattern of flight from rural areas into the major economic centers of Libreville, Port Gentil, and Franceville. Libreville was most affected by this migration because the oil industry also facilitated rapid increases in state spending leading the government to become the country's largest employer. ${ }^{49}$ Libreville today still has an extremely oversized bureaucracy. Since Gabon controls little of the major private commercial sectors in the country, Gabonese who are looking for reasonable employment have little choice but to turn to the state administrative system.

Prior to the oil booms, there had been small groups from other African countries that migrated to Gabon for economic opportunities. During the height of the country's oil boom in the 1970s, however, it became readily apparent that the country's small population would not be able to fulfill the increased workload for oil-related projects such as the Transgabonais Railroad or the conversion of Libreville from a quiet 
colonial town to a more modern economic center. Therefore, the government kicked off a vigorous campaign to recruit foreign laborers to move to Gabon's urban centers. As a result, thousands of Africans from around West and Central Africa came to work in the booming Gabonese economy. The campaign worked so well that by the mid-1980s approximately 100,000 immigrants moved to Gabon, and the country's non-Gabonese population was almost 20 percent. 50

Prior to and continuing during this immigration influx, Gabon's post-colonial government successfully created an identity around the idea of Gabonese entitlement. The Gabonese, as M'Ba and Bongo claimed, were special because of their country's wealth. As one author who lived in Gabon during part of the oil boom years of the 1970s and early 1980s described it, "I often heard Gabonese proudly refer to their country as being wealthy, reflecting their president's comments that Gabon was like a beautiful young woman with many suitors. Some assumed that simply by being a citizen of Gabon one was entitled to a comfortable government office job at decent pay, and for a time the Gabonese state could almost guarantee this." ${ }^{1}$ Other outsiders also noted the existence of a popular image of a Gabonese seated on a throne, with a "Ghanaian to shine his shoes, a Beninois to drive him around in a taxi, a Cameroonian to sell him things to eat, and an 'Equato' (Equatorial Guinean) to take care of his household."52 
Often this over-nationalistic pride resulted in violence between Gabonese and immigrants. One famous incident involved a 1981 soccer match that led to violence directed at Cameroonians, a group that was reported to supply almost 75 percent of Gabon's food by 1981.53 On May 20, a fight broke out among players during a soccer match between Douala and Libreville. Two days later, photos published by the Gabonese newspaper the L'Union showed Gabonese players lying on the turf, apparently injured. Whether these injuries were real is not known, but the photos incited mob violence against Cameroonians. One eyewitness described seeing "an angry crowd that surged through an open-air market, indiscriminately attacking Cameroonians, (Equatorial) Guineans, Malians, and Voltaics. Cameroonians driving taxis were pulled from their cabs, assaulted, and the vehicles confiscated or simply stolen." Throughout the riots, eyewitnesses described seeing Gabonese police stand by doing nothing, either ordered not to or too afraid. ${ }^{54}$ Cameroon immediately began evacuating its citizens, airlifting out 6,000 within days, and up to 10,000 shortly after. ${ }^{55}$

Bongo, like M'Ba before him, has always encouraged nationalistic xenophobia as a way to divert attention from his government. As the country's oil bubble burst in the mid-1980s, however, the need to divert attention from the government became more urgent. As the Gabonese economy began its decline, from which it has never recovered, Bongo 
unleashed the government's most blatant attack on non-Gabonese residents. In a speech at the end of 1984 to the PDG, published in L'Union, Bongo cited immigration as the reason for the country's problems and declared that immigrants must be brought under control. Bongo let loose a burst of anti-foreign invective. He first targeted prostitutes, claiming that all the women plying this trade in Libreville were foreigners. He authorized the gendarmerie to send out trucks to round up these women and then rather crudely suggested, "Then we will leave them to the army. Once five or six soldiers have been on top of them, perhaps they will understand that we don't tolerate street-walking in Gabon." Next he moved to attack immigrants who "enter Gabon and leave as they wish," spreading "disharmony among Gabonese" and "murder[ing] the national economy." 56

When mob violence formed this time, it was directed mainly at Lebanese nationals. The Lebanese community was singled out for cheating the Gabonese population by not paying customs duties. Immediately after Bongo's speech, crowds in Libreville began looting Lebanese stores. ${ }^{57}$

Since Gabon's economy has began its slow decline, Bongo has continued his attacks on immigrants, primarily African immigrants, 
blaming them for increases in crime, prostitution, and various other problems. Of course, the government has never really worried about prostitution or anything like that. Instead, it is concerned about developing a foreign underclass of unemployed that chooses to stay in Gabon because the economic conditions in their home countries are worse.

According to the U.S. State Department, by 1992 Gabon, a country of slightly more than 1 million people, had an estimated 200,000 nonGabonese residents. The attack on black African immigrants has continued from the mid-1980s, through the 1990s, and up to today. Citing that it intends to bring the immigrant population "under control" and preserve employment opportunities for Gabonese, the government began instituting extremely strict immigration and visitation policies. The government's first official act in 1986 was to begin requiring foreign workers (excluding French and American) who received a work permit from the Ministry of Labor to purchase $\$ 200$ US identification cards. Immigrants were also required to pay repatriation fees equivalent to the price of a ticket back to their country, with an additional 20 percent in administrative costs added. On top of all this, immigrant workers had to pay an additional $\$ 1,000$ US if they intended to visit their home country and travel back to Gabon. ${ }^{58}$ 
More and harsher immigration and visitation policies have followed, which has led, intentionally and unintentionally, to cruel treatment of foreigners. Creditable reports have cited Gabonese security forces severely beating black immigrants and detaining them in harsh conditions for long periods of time. ${ }^{59}$ In the early to mid-1990s, the government began a massive roundup of foreign African workers-most of who were encouraged to migrate to Gabon not long ago. Starting in late 1993, the government began extremely aggressive campaigns to arrest or deport immigrants. Many were separated from families they began while living in Gabon. Those arrested were jailed in poorly maintained prisons, where a number died.60 In September 1994, the government issued an ultimatum to all undocumented workers, which were the overwhelming majority of immigrants, to leave the country or obtain their papers before January 31, 1995. Visa fees for workers ranged from more than $\$ 1,000$ for Malians to a mere $\$ 95$ for French. 61 Fearing violence or arrest, an estimated 60,000 to 70,000 immigrants fled. 62

Today the residue of colonialism still covers Gabonese society. Gabon's factionalism creates serious obstacles to any type of development initiative, including ecotourism. 
Post-colonial Gabon's Ecotourism Challenges

In chapter 2, I discussed some common problems associated with Third World tourism. In the remaining sections of this chapter, I try to explain a number of Gabon's own challenges to ecotourism development. Some of the problems discussed here are quite unique to Gabon and others are common among other Third World countries that have attempted ecotourism development. Most of these problems, however, are in someway tied to the effects of a relatively recent colonial experience and the socio-political climate it created.

Political Corruption

Nowhere are the effects of colonialism more apparent in Gabon than in the country's political system. As is often the case after colonial forces step aside, a leadership vacuum was created in the country. At the national level, as discussed, this vacuum was filled by an autocratic regime that largely answered to French interests. At the local level, for the large part this vacuum persists, making it difficult to confront a number of problems, some of which are discussed in later sections of this chapter.

Politically leadership has remained consistent. Since the failed 1964 coup against former President M'Ba, the French-sponsored Gabonese government has managed to maintain control despite a number of instances of violence. Political and social unrest caused by 
the recent economic recession have led to deterioration in security. Theft and mugging incidents are on the rise, and visitors are advised not to walk the streets after dark. Displeasure over national leadership and the economy has led to a number of mass protests, many of which have turned violent.

As far as personal freedoms go, Gabon is not extremely oppressive, but there are serious political rights abuses. Freedom House, an international nonprofit that monitors political rights and civil liberties, rates the Gabonese government's treatment of political rights as a five, or partly free, on a scale of one to seven. (One is the best rating.) Rights of the press are technically guaranteed, but are frequently restricted. There is only one daily newspaper in the country, which is controlled by the state. At least six private radio and television stations have been licensed to operate in Gabon, but their programming is mainly nonpolitical. Internet access, however, is not restricted. In late 2004, the government's national agency in charge of monitoring media content suspended two private newspapers and renewed a suspension of a third one. This follows the suspension of two magazines and warnings to a couple others in recent years. Several of these media outlets have been involved in reporting human rights abuses and corruption by the government. 
Bongo rules Gabon with a heavy hand. Despite the reforms since 1990, the Gabonese have never really had an opportunity to change their government. There are numerous political parties, but Bongo's Gabonese Democratic Party (PDG) has ruled since it was created in 1968. In more recent years, Bongo has eliminated legislation and other efforts to limit his power. In 2003 , his party removed a constitutional amendment that imposed term limits on the president, allowing Bongo to stay in office indefinitely. The PDG won the overwhelming majority of seats in the last parliamentary elections, with many voters complaining of government interference at the polls. Some opposition parties also boycotted the election. There are local human rights groups, but they are mainly weak and not entirely independent of the government. Torture to produce confessions and arbitrary arrest for long periods of time are common.

\section{Severe Stratification}

Even at the height of Gabon's economic success, the country remained extremely stratified. While it still enjoys one of the highest per capita incomes in sub-Saharan Africa, it is estimated that half of the population lives below the poverty line. ${ }^{63}$ Colonial development and the oil boom left behind a country marked by a number of small isolated settlements that are separated by totally unpopulated terrain. The country's small and sparsely distributed population is a major constraint 
on development. ${ }^{64}$ The majority of state revenues are allocated to three main economic centers. In 1990, it was estimated that roughly 80 percent of the country's GDP was in the hands of only 2 percent of the population. ${ }^{65}$

A major contributor to the country's small population is the fact that Gabon is plagued by poor health conditions, which are aggravated by the hot and humid climate. Gabon is more affected by malaria than any country in sub-Saharan Africa. The country experiences high rates of infant mortality (86 per 1,000 live births in 2001) and maternal mortality (an estimated 600 deaths per 100,000 live births). ${ }^{66}$ Also high are the country's rates of infertility, which are, in part, believed to be caused by the country's unhealthy climate and high levels of toxic minerals in the topsoil. The country also faces an increasing problem of male impotence, which affects 25 percent of adult men, caused by high levels of alcohol and tobacco use. ${ }^{67}$ AIDS is an additional rapidly growing crisis. As with other parts of Africa, the disease has reached catastrophic proportions. The World Health Organization (WHO) estimated that in the year 2000 more than 7 percent of sexually active Gabonese between the ages of 18 to 45 had been infected with the disease. Estimates of the current adult population infection rates range from 4 to 9 percent. At the turn of the century, there were already more than 8,000 AIDS orphans in Gabon. 68 


\section{A Decimated Culture}

Gabon's traditional culture has been decimated by its colonial experience and the onslaught of Western oil and timber money. French influence remains exceedingly strong. In the 1970s and 1980s, the oil industry intensified the kinds of interactions Westerners had with citizens. By the early 1980s, almost every child had received some Western-style primary education. In addition to further legitimizing the post-colonial dictatorial government, this also facilitated the spread of French. ${ }^{69}$ Today the Gabonese are considered some of the most proficient French speakers in all of Africa, and the country's school system is structured much like France's system. ${ }^{70}$ The quality of life in colonial and post-colonial Gabon was tied to learning French language, habits, customs, and tastes. Those that better learned to adapt to their foreign rulers increased their chances for a better life or at least minimized suffering. ${ }^{71}$

The lack of cultural appeal is a major drawback to the country's tourism goals. As explained in chapter 2, most travelers, even ecotourists, are interested in cultural experiences. I learned this lesson the hard way after calling hundreds of travel planners across the country to speak with them about WildLaw's Gabon project. In April 2004, WildLaw's development director made a 30-minute presentation to more than 300 travel planners at the annual African American Travel Planners 
Conference in Kansas City, Missouri. The job delegated to me was to put together a mailer for all the attendees and afterward call each of them to see who was interested in traveling to Gabon. After calling roughly 100 travel planners I came to the conclusion that the effort was futile. Of the travel planners I spoke to who did have a background in international travel and clients interested in traveling outside the country, the overwhelming majority said that they and their clients were not interested in environmental tourism. Most were interested in cultural and historical tourism experiences. No matter how much I tried to entice them with information on Gabon's history or culture, the "eco" part of our tour immediately turned most of them off. One travel planner put it rather bluntly: "I can see monkeys in the zoo," she said. "I want to see Africa when I travel to Africa."

\section{Child Slave Labor}

As mentioned in one of the preceding sections, Gabon has a long history of importing labor. After massive exodus of foreign workers, everyday life in the country became a little more difficult because of a shortage of people to perform jobs such as driving taxis, work in fisheries, and especially work on farms. In more recent years, many Gabonese have started performing duties they once shunned. ${ }^{72}$ However, the demand still remains high for cheap, exploitable labor. 
This has led to the country's most glaring human rights problem: its child slave labor trade.

Gabon has come under scrutiny in recent years for the exploitation of thousands of children who are sent from other Central and West African countries to work as domestic servants. A study by the U.N. Children's Fund (UNICEF) found that child smuggling into Gabon has increased in the wake of Gabon's economic problems. These children are shipped from provider countries, mainly Togo, Benin, Burkina Faso, and Mali, to countries like Gabon with the promise of a better life and educational opportunities. What they find is a life of domestic servitude, where the majority work on plantations, with many others working as street vendors. UNICEF found a tremendous market for cheap labor in Gabon. Of the 132,000 children living in Gabon, 53,000 are forced to work, according to the International Labor Office. ${ }^{73}$

Sex Trade

Even with as little tourism as Gabon receives currently, it is already facing a significant sex trade problem. Brothels in Libreville have long been popular with Europeans, dating back to Gabon's earliest experiences under colonialism in the mid-to-late 1800s. In fact, prostitution became so closely linked with African-European unions that the term "prostitution" was synonymous with mix-race unions from 1860 to 1914. A colonial atlas written c. 1900 noted about Libreville, "The 
women are pretty, and the ease of their moral (sic) has given Libreville something of a reputation as a black Babylon."74 Many of the children shipped to Gabon are also caught up in the sex trade. While most of these children go to work in plantations or for families who claim them as their own children, many end up as de facto sex slaves. ${ }^{75}$

Brothels are now popping up around some of the national parks. After visiting Gabon, one member of WildLaw's staff informed me of a "fishing camp" located right next to a national park where Western businessmen visited to have sex with local women. When I asked a tour guide in Gabon about the place, he was reluctant to say anything about it other than it existed and the local tour operators were working to solve the problem.

\section{Lack of Rural Development}

Development efforts during Gabon's colonial period focused foremost on Libreville. The development of mineral exploration industries exacerbated this problem after Gabon received its independence. As a result, there was little importance placed on rural development. Even those efforts made to better the lives of rural Gabonese were halfhearted. While admitting that rural development was not its number one priority, the government did create several agencies, including the National Office for Agricultural Commercialization, in the 1960s to supposedly stimulate rural economies. The vast majority of 
money spent on these agencies, however, went to administrative expenses. As a result, the majority of money intended for rural development was actually spent in Libreville. ${ }^{76}$

The community most affected by the neglect of any rural development is the agricultural community. Excluding commercial logging, there is not much of an agricultural sector. Farmers have been challenged by the country's difficult topography. The densely forested countryside is not well suited for farming. Most of the topsoil in Gabon is difficult to till. It is difficult to raise cattle or pigs because they need plains on which to forage. The country's agrarian sector is not even able to feed itself, much less the nation's growing urban populations. Malnutrition is very common in rural society. 77 The malnutrition problem has much to do with the lack of protein available. Malaria and Trypanosomiasis have had a tremendously adverse effect on the country's small cattle industry. ${ }^{78}$ Livestock such as pigs, goats, and chicks are treated as savings or insurance items rather than typical dietary sources. ${ }^{79}$ The absence of a functioning agricultural sector presents a number of challenges to ecotourism development. Most important of these is the increased consumption of bushmeat because of a lack of protein sources (explained in later sections). 
Traveling To and Around Gabon

Gabon has done very little in the past to develop its tourism industry. Much of this has to do with the fact that in the past there was never any incentive to invest in other development initiatives with the country's mineral extraction industries doing so well. Another reason has to do with Gabon's nationalistic xenophobia. Getting into Gabon is tremendously difficult, even for Western visitors. Because of the antiimmigration and pro-nationalism atmosphere within the society, the government has instituted some of the most difficult and expensive visa requirements in Africa. As Lonely Planet, an outfit that advocates socially and environmentally conscious tourism, puts it, Gabon's "authorities seem to regard virtually all foreigners with suspicion."80 All foreign travelers to Gabon must obtain a visa, and they must be obtained prior to arriving in country. They also are not available at border crossings. Obtaining a visa is notoriously difficult from outside Africa, costing more than $\$ 100$ US. Visa requests can also be rejected without explanation or delayed for weeks. As a result, it is recommended to obtain a visa at the embassy of a bordering state, which can take a week or more since applications have to be referred to Libreville by telex. The costs for getting a visa this way varies from about $\$ 26$ to $\$ 55$. On top of this, there is usually a $\$ 20$ telex fee. By comparison, visas to visit popular ecotourism countries in Africa, such as Kenya and South Africa, 
are usually free to Western visitors and can be easily obtained at the airport upon arrival.

Getting to Gabon is just as difficult as getting in. There are no direct flights to Libreville from the United States or most of Europe. Travelers from the United States must take Air France into Paris. There are four flights a week from Libreville to Paris. Once you are in the country, traveling does not get any easier. Migration to Gabon's urban centers because of the oil industry has created an extremely sparse and almost completely undeveloped rural country. There are few roads outside of Libreville, and many of those in town are poorly maintained. Except for the routes from Libreville to Ndende, Booué, and Bitam, the roads are not in good condition and can be fairly hazardous, especially in the rain. Of course, having little development outside of Libreville does have its good side. Part of the reason that Gabon's forests are so pristine is because of the difficulty of traveling.

There are 65 public airfields that handle in-country air traffic and an additional 50 private ones that are mainly used by forestry and petroleum companies. Rail service is available from Libreville to Booué, Ndjole, and Franceville. There are some 6,000-hotel beds in the country, but the overwhelming majority are located in Libreville. Accommodations range from the African five-star Intercontinental Hotel in Libreville to lodgings without electricity and running water. 
Price Gouging

The invasion of wealthy European and American businessmen over the years has helped create a high cost of living. A frequently cited reason so few tourists have visited Gabon is the country's very high costs of living. One of the reasons for the high costs is price gouging. As previously mentioned, the Gabonese control essentially none of the means of production for the oil and logging industries. As a result, of the roughly 120,000 foreigners who visit Gabon every year, the vast majority are employees of energy companies. ${ }^{81}$ And wherever energy company representatives with large expense accounts travel, price gouging is sure to follow. As a result, the Economist Intelligence Unit consistently ranks Libreville as one of the world's most expensive cities, ahead of New York, Paris, and London. This is not good for Gabon's ecotourism prospects. The idea of paying $\$ 15$ U.S. for a hamburger is enough to scare off many of the hardiest eco-travelers.

No International Image

Despite all the financial support that has gone into the infrastructure and training for ecotourism, so far there seems to have been little emphasis placed on raising awareness of Gabon in the developed world. When approached about participating in the study for this paper, several academic experts on ecotourism actually admitted to having never heard of Gabon. One prominent ecotourism author 
actually declined to participate after seeing a questionnaire by stating flatly that he could "not even find Gabon on a map." Internationally, Gabon is still seen as an oil-producing state instead of a tourist destination. Only about 1 percent of visitors to Gabon in 2002 were tourists. ${ }^{82}$

How Gabon addresses its identity crisis will be a major factor in determining whether it will ever become the major destination the government is hoping it will become. Aside from WildLaw, there have been few if any American environmental nonprofits or travel organizations that are recruiting prospective tourists to go to Gabon. After a May 2004 meeting on ecotourism in Gabon in Washington D.C., attended by dozens of representatives of private businesses and nonprofits and sponsored by the Overseas Private Investment Corporation (OPIC), WildLaw representatives came away believing there were no other groups in the United States working to bring tourists to Gabon. One attendee of the meeting, who happened to be the head of a major international environmental NGO, stated that Gabon will never be a serious ecotourism option for travelers. In his view, Ghana was the real choice for tourists looking to see tropical Africa.

\section{The "Meatiest" Problem}

Many in the ecotourism industry have refused to take Gabon seriously as an ecotourism country until the government makes, in their 
view, a major attempt to stamp out the country's thriving bushmeat trade. This objection was brought up to me when I tried unsuccessfully to gain a letter of support for WildLaw's Destination: Gabon project from Jane Goodall. A representative of the Jane Goodall Institute (JGI) told me that Goodall wanted to look into what was being done in Gabon to improve particular problems; one of the most important among these was the illegal bushmeat industry.

"No one starves in Gabon because of all the bushmeat that's available," a Peace Corps volunteer serving in Gabon told me during this study. Bushmeat hunting was once thought by environmental NGOs to be mainly an activity of the dwindling Pygmy population. Today, however, it is recognized as a problem that reaches well into the mainstream of society. The Bushmeat Crisis Task Force (BCTF), a U.S.based umbrella group consisting of groups such as the WWF, WCS, CI, and the JGI, estimates that more than one million tons of wildlife are killed each year for food in Central Africa. 83 Bushmeat is more prevalent in rural areas, but it also exists in every urban center in Gabon as well. Unlike illegal drug trades in countries like the United States, the bushmeat trade is fairly obvious in Gabon and other parts of the Congo Basin. A significant part of the Gabonese population draws its income, directly or indirectly, from the bushmeat trade. In Libreville, one can easily find a market square with vendors lined up to sell chimpanzee 
hands, gorilla skulls, or round slices of elephant trunk. For the Gabonese, a typical Christmas meal often includes monkey, chimpanzee, gazelle, or wild boar. ${ }^{84}$ As one environmental researcher put it in an interview for the New York Times, "People don't want beef or chicken anymore-they call it 'white man's meat.' I know a woman who has to take chimpanzee meat to her family whenever she goes home. You can order a gorilla for Christmas the same way I'd order a turkey."85

Of course, killing and selling endangered species is illegal; but laws against the activity are rarely enforced. In the past, there has been a lack of political will for the government to seriously clamp down on the bushmeat trade or the rampant corruption that allows it to take place. But even as the will to enforce laws has strengthened, enforcement agencies still lack the necessary infrastructure to properly combat poaching. Hunters often receive their weapons from under-staffed police and army officers who are supposed to stop the practice. While there are frequent checkpoints everywhere for police to seize illegally killed animals, bushmeat traders are often able to sneak through by cleverly hiding animal body parts in hard to search places such as the engine of a logging truck. Even when illegal meat is found, a bribe of little more than $\$ 2$ US is often enough to get through. One gorilla carcass is worth up to $\$ 50$ or $\$ 60$ US, or 30,000 Central African francs. ${ }^{86}$ As one law enforcement official explained: 
When I came here in 1988, it was forbidden to kill animals. But we (law enforcement officers) had guns then. We had vehicles. We had bullets. Now, with the economic crisis, the central government gives us nothing. We can't do our jobs. ${ }^{87}$

Adding to the enforcement problem is the continuation of logging deeper and deeper into forests. Logging companies bring roads, trucks, and hungry workers and their families into areas of the forests that were, until the loggers appeared, inaccessible. As loggers push deeper into uncharted forests, the power of the government grows even weaker. In these so-called "frontier zones," it is the timber companies, and not the government, that have sovereign authority. In these territories, even environmental researchers admit, it is hard for the government to police the trade, or even tell exactly what is going on. 88 Sometimes logging companies are more than just an indirect cause of the problem. At times logging company managers pay hunters directly to round up food for their employees. Other times the company may provide a hunter with a ride into the forest-or even weapons-in exchange for a portion of the kill. 89

Increased logging concessions are not the only factor contributing to the spread of the bushmeat trade in Gabon. An increase of global trade has also had an adverse effect on the country's wildlife population. In January 2001, the Convention on International Trade in Endangered 
Species (CITES) formed its Bushmeat Working Group to examine the causes and possible solutions to the bushmeat trade in Central Africa. The Working Group found that the increasing commercialization of the trade was having a serious impact upon Gabon's wildlife. According to CITES' study, some 68 species of wildlife in Gabon were threatened by increased poaching. 90

It is easy for those in the developed world to quickly condemn the bushmeat trade. But those in the conservation movement should attempt to take a look at the issue through the eyes of the individuals who kill and eat rare wildlife. In a country with an agricultural industry that does not even raise enough food to feed farmers-much less the rest of the population-people often eat wild meat because of the lack of alternatives. Bushmeat is a cheap and currently plentiful source of protein in regions where often meat from traditional sources is scarce and more expensive. Domestic food production has dropped 13.6 percent in the last 40 years. As a result, excluding bushmeat, almost all of Gabon's protein sources are imported. 91

Aside from its nutritional value, however, bushmeat has become a part of Gabonese culture and heritage. Even if other sources of meat were readily available, there would still be a bushmeat problem. A study published in February 2005 in the journal Conservation Biology provided evidence to support this observation. Researchers found that lower 
prices for traditional livestock did not appear to influence the level of bushmeat consumption in households in Libreville and Franceville. ${ }^{92}$ In fact, in Libreville, as with other larger cities in Central Africa, bushmeat can actually be more expensive than imported beef or poultry. While bushmeat is cheap in rural areas and small cities, the transfer of meat from the forest into big cities often causes the price to increase to two or three times more than its original value. Consequently, many of those who chose to eat restaurant-bushmeat in places like Libreville do so because of cultural preferences-not because of the price. ${ }^{93}$ The Gabonese value their rural, hunting history. Eating bushmeat is part of their identity. The various languages of Central African cultures reflect how much the concept of eating exotic wildlife is a part of society. For example, in Lingala, a Central African language that spans ethnic groups, the word "eyama" means both meat and wild animal. 94 The eating of bushmeat is surrounded in myths about the supposed benefits. Gorillas and chimpanzees look like humans but have superhuman strength. Therefore, their meat is believed to make you stronger. Ape meat is meant to be an early part of a child's diet so he or she can grow up healthy. Adult males eat ape meat to increase their sex drive. Wild animals are used for more than just food, too. Animal meat and body parts are believed to have medicinal significance. You can treat broken bones with a heated chimpanzee skull. Chimpanzee hands cure 
stomach pains, and their hipbones reduce the labor pains of women. Athletes collect gorilla body parts for strength. Of course, these superstitious beliefs apply to more than just apes. Elephant skin is used to scare off your garden pests for example.

One should note, as mentioned earlier, that there are more than 40 different ethnic groups in Gabon. So any generalization about the cultural beliefs regarding bushmeat can have a number of exceptions. Different ethnic groups may find the killing of a particular animal appalling. For example, a 1960s survey of Fangs by a Spanish zoologist found that many tribal members thought the idea of killing and eating chimpanzees was awful because of how human-like they are. But with each exception, there are also reinforcements of the norm. The same study also found that many Fang tribal members thought gorilla meat was delicious. ${ }^{95}$

Even many in the environmental community and organizations such as the CITES working group say that some forms of bushmeat are acceptable and can be carried out in a sustainable manner. In fact, if hunting wildlife remained an activity engaged in by small tribes of Fang, M'Beti, or pygmy groups using spears and crudely fashioned weapons, as was done for years, then hunting animals to extinction may never have occurred. 
The current size of the bushmeat trade, however, cannot be sustained. Increases in human populations, the availability of guns, and the ease of transportation have all led to unsustainable levels of hunting. Apes are especially vulnerable to increased poaching. Apes, particularly gorillas and chimpanzees, reproduce slowly. As with human children, each primate child relies on a long, intensive period in which it learns self-reliance. Each offspring requires a high level of parental involvement. Apes and monkeys also tend to travel in groups, making them easier pray. Mandrill monkeys travel in groups of 50 to more than 100. Studies have stated that gorilla and chimpanzee populations can sustain hunting rates no higher than 1 to 4 percent of the population. By comparison, rodent populations can sustain losses of anywhere from 13 to 80 percent yearly. ${ }^{96}$

Wildlife hunting, along with frequent outbreaks of the Ebola virus, have cut the gorilla and chimpanzee population in Gabon and neighboring Congo in half since 1983.97 In a study published in 2003, researchers John E. Fa and Jessica Meeuwig called the problem of the bushmeat trade "catastrophic" for not only wildlife, but also the people who rely on the trade for food. They concluded that there will be a significant decline in the availability of wildlife protein by 2050 in the Congo Basin. In addition, Congo Basin countries will also be largely 
unable to replace bushmeat with other protein sources. ${ }^{98}$ This is already much the case in Gabon.

Tourism Impacts of Bushmeat

The direct impacts of the bushmeat crisis on Gabon's chance to become an ecotourism destination are fairly obvious. If the country loses its wildlife diversity, it loses its most important attraction for tourists. But there are consequences of the bushmeat trade that adversely impact the lives of the Gabonese and can also affect the country's ecotourism goals. For one, there is an ethical aspect to bushmeat-especially when it comes to apes - that is likely to turn away many environmentally conscience travelers. Apes are more than mammals; they are our genetic relatives. Gorillas on average share 97.7 percent of our DNA.

Chimpanzees, our closest relatives in the animal kingdom, share on average 98.7 percent of our DNA. Chimpanzees are biologically so similar to us that a human being can actually receive a blood transfusion from one. Apes share our habits. They have a similar thought process; they live and travel in similar families; and they even experience similar emotions. Thus, eating an ape is only one step away from eating a human. And seeing ape on the menu at a Gabonese restaurant is not likely to sit well with Western visitors, especially your typical ecotourist. There are also many health concerns involved with bushmeat. In October 2001, an Ebola outbreak hit the Gabon-Republic of Congo 
border. Gabon's Health Ministry reported 65 cases of the disease, including 53 deaths. In the Republic of Congo, there were 43 deaths. The World Health Organization (WHO) traced the origin of the outbreak back to contact with an infected gorilla. 99 The Ebola virus, named after a river in the Democratic Republic of the Congo, is one of the world's deadliest diseases. In a typical outbreak, 50 to 90 percent of individuals who contract the virus die through massive blood loss. Within a week of contracting the disease, an Ebola-infected individual begins to feel chest pain, shock, bleeding, and can experience blindness. The disease is spread through contact with the body fluids of a carrier; and primates make excellent carriers. In February 2004, WCS released a study that found every Ebola outbreak from 2001 through 2003 in Gabon and the neighboring Republic of Congo has been directly linked to bushmeat. The majority of these incidents have been linked to meat from gorillas or chimpanzees. 100

Since the disease first appeared in the Democratic Republic of the Congo (then Zaire) in 1976, ${ }^{101}$ there have been several confirmed outbreaks of Ebola linked to bushmeat. Gabon itself has been home to several. After an outbreak in Mekambo (about 500 kilometers northeast of Libreville) in 2001, the Gabonese government showed some willingness to enforce its long-existing ban on distributing bushmeat. As to be expected, however, the stepped up enforcement was not met with 
popular enthusiasm. ${ }^{102}$ While the government did take further steps to reduce the size of the bushmeat trade, it never made a real attempt to completely eliminate hunting of rare wildlife. The government's enforcement tactics consisted of daily radio announcements on how to avoid Ebola. Besides the problem that most rural Gabonese do not have radios, the announcements did not take a tough stand against killing and consuming wildlife. Announcements by government ministers informed the public that people should avoid eating any apes found dead or acting strangely. This of course implies that it is acceptable to hunt and eat apes that appear normal. ${ }^{103}$

AIDS is another disease that has been closely linked to apes. In 1999, scientists announced that HIV-1, the most common HIV virus, came from the subspecies of chimpanzees called pan troglodytes. The best evidence to support their conclusion was the findings of tests on two wild-born chimpanzees from Gabon that tested positive for antibodies to simian immunodeficiency virus (SIV), the primate version of HIV.104 Since apes do not seem to get sick from the disease, researchers believe they may contain the cure. It is imperative that they are not killed off in order for AIDS research to continue.

When it comes to discussing the health-related consequences of bushmeat, it should be noted that there is essentially no health threat to tourists from bushmeat. There is no evidence that anyone has ever 
contracted Ebola from purchasing a bushmeat product at a market for example; and it is highly unlikely that environmentally conscience tourists would engage in such a transaction anyway. But outbreaks of Ebola from bushmeat have already created somewhat of an image problem for Gabon. Although a rational human being is capable of examining the evidence to conclude that Ebola poses no threat to him or her, the simple truth is that people do not always think rationally. Ebola is an alien disease to Westerners. Their knowledge of it is drawn almost entirely from 60-second nightly newscasts during an outbreak far away or from highly fictionalized entertainment sources such as the Hollywood movie Outbreak. Diseases such as Ebola, much like civil conflict, are another stereotypical fear that Westerners, and especially Americans, have about Africa. While there is no excuse for unfounded fear based on stereotypes, there is no denying that the spread of exotic diseases often keeps tourist dollars away.

Confronting the bushmeat problem will be a necessity for the Gabonese government if Gabon is going to become a popular ecotourism destination. There are a number of possible approaches to dealing with the problem, some easier to implement than others. Some of the problems that contribute to the boom of the trade such as corruption in enforcement agencies will require more comprehensive approaches to political development in Gabon. As mentioned in other sections of this 
chapter, corruption flourishes in the absence of social and organizational structure. Without creating the necessary local support for reducing bushmeat, these problems are not likely to go away. (A more detailed discussion on how to address these and other problems associated with the bushmeat trade are in chapter 5.$)$

Public information campaigns targeted at protecting the most vulnerable animals are one step. Right now there is no control over the type of animals that are killed even though there are technically laws protecting certain species. These campaigns should also attempt to dispel many of the myths regarding the supposed benefits of bushmeat. Similar public information campaigns were able to reverse the cultural popularity of whale meat in Japan.

The government is already making some attempts to stimulate food production in order to reduce the volume of imports. This is a good first step to improving the country's struggling agricultural industry. If the Gabonese had the opportunity to buy fresh, domestically raised poultry and beef, instead of frozen imports from France, there would be less need for bushmeat. These general, yet important, steps can help to vastly alleviate the bushmeat crisis, and advance Gabon toward its goal of becoming a conservation world leader. 
Accomplishments So Far

The most important step taken toward establishing Gabon as an ecotourism destination has been the creation of its 13 national parks totaling more than 4,000,000 hectares. Ironically, this step was most likely made easier because of the post-colonial, autocratic national government that exists. Bongo's more than three decades of rule have provided him with the ability do almost anything he wants with little to no opposition. When conservationists inspired him with their arguments of ecotourism, they had effectively done all the lobbying required to get Gabon's park system created.

In addition to the 13 national parks, the government has also established several other protected areas such as animal sanctuaries and nature reserves for educational purposes. Some of the parks with the best potential for high tourist interest follow: 


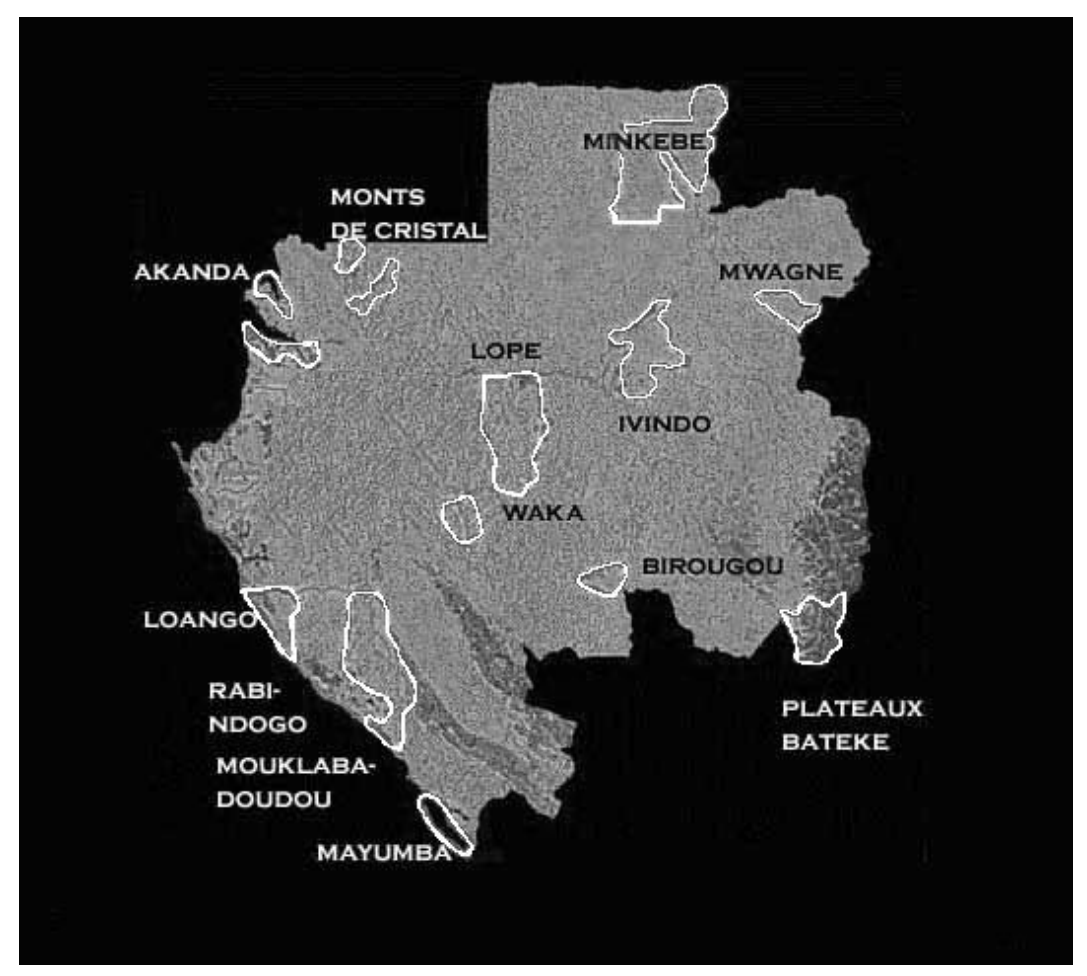

Figure 2. National parks map adapted from park service's website

\section{Akanda National Park}

At 54,000 hectares, Akanda is the closest park to Libreville but can only be reached by boat. Bordering on the Mondah and Corisco bays, Akanda hosts the largest population of migratory birds in the country and is a rich breeding area for fish and wildlife. It is also a feeding zone for turtles.

\section{Ivindo National Park}

Between the Ogooué and Ivindo rivers, Ivindo park, 300,000 hectares, has some of the most impressive waterfalls in Africa. Ivindo is home to Langoué Bai, where Mike Fay discovered naïve gorillas. It has 
one of the largest concentrations of forest elephants and gorillas, which is sure to make it popular for wildlife viewing. The river network that runs through the park makes it possible for canoe and kayaking expeditions. Ivindo also hosts one of the largest bird species of the country's parks, with 430 currently discovered.

\section{Loango National Park}

With 100 kilometers of undisturbed coastline, Loango National Park, 155,000 hectares, has the possibility of offering a broad assortment of beachfront activities. Forest elephants, forest buffalos, hippos, gorillas, and leopards frequent its beaches. It is also a great location for whale watching, an activity that is becoming increasingly popular with ecotourists.

\section{Lopé National Park}

Right dead in the center of Gabon is Lopé National Park, 497,000 hectares. The Ogooué River runs directly through the park. Lopé was the country's first protected area, designated as a protected site more than a half century ago. Research on gorillas and chimpanzees has been conducted there for more than a couple of decades. The rock engravings in Lopé are among the oldest in Central Africa, dating back approximately 400,000 years. According to the government, Lopés thousands of mandrill monkeys are the largest gathering of primates known in the world. It is also the last known home of the Solatus 
monkey. The train ride from Libreville to Lopé takes four and a half hours, which makes Lopé a comparatively easy destination to reach in Gabon.

\section{Mayumba National Park}

Mayumba National Park, the smallest in the country at 8,000 hectares, has the potential to rival Tortuguero National Park in Costa Rica as the principal viewing and research site for leatherback turtles. According to some estimates, it has the largest concentration of nesting leatherbacks in the world. Turtles travel from as far away as Brazil to nest in the area.

\section{Batéké Plateaux National Park}

In the far southeastern corner of the country on the Congo border is Batéké Plateaux National Park, 205,000 hectares. The park is located near the town of Franceville, which has a fairly impressive hotel compared to the lodging facilities near the other national parks.

Franceville is one of the better sites for interesting cultural experiences, which are few outside of Libreville. The park also houses the Project Protection of Gorillas, where private research is conducted to protect apes.

\section{Minkébé National Park}

Minkébé is the largest park in the country, 757,000 hectares. The park contains a massive forest and a number of mammals that are hard 
to find other places in the country, including giant forest hogs and forest antelopes.

\section{Help Is On the Way}

The overwhelming majority of work put into establishing ecotourism in Gabon so far has been conducted through the Congo Basin Forest Partnership (CBFP). The CBFP is an initiative of governments, NGOs, and members of the private sector formed to halt biodiversity loss and foster sustainable development in the forests of the Congo Basin. Former U.S. Secretary of State Colin Powell announced the partnership's creation on the last day of the 2002 Johannesburg Earth Summit in which Bongo also announced Gabon's ecotourism initiative. The United States has pledged $\$ 53$ million over a four-year period for the partnership. Much of this money is being dispersed through agencies such as the U.S. Trade and Development Agency (USTDA) and the Overseas Private Investment Corporation (OPIC). While the partnership is technically a venture to help conservation initiatives in all six Congo Basin countries (besides Gabon, this includes Cameroon, Central African Republic, Democratic Republic of Congo, Equatorial Guinea, and the Republic of Congo) undoubtedly a healthy share of this money will go Gabon's way. In addition to the partnership, several other developed countries, including Germany, France, and Japan, have also expressed interest in investing in Gabon's ecotourism initiatives. 
Prominent international NGO members of the partnership, mainly CI, WCS, and the World Wildlife Fund (WWF), have also pledged to raise an additional \$37.5 million US for conservation initiatives in the Congo Basin over the next 10 years. ${ }^{105}$ CI has enlisted the assistance of some of its many corporate partners to help with the cause as well. In November 2003, CI and Starbucks coffee company organized a fundraiser spotlighting CI's conservation efforts in the Congo Basin. Featured speakers included Starbuck's CEO Orin Smith, Mike Fay, and actor Harrison Ford. CI hailed the event, which attracted nearly 800 people and raised $\$ 1.7$ million, as its most successful ever. ${ }^{106}$ Money raised through the CBFP will be a tremendous financial boost to Gabon in its goal of ecotourism success. But money alone will not get Gabon where it needs to be.

\section{A Long Way to Go}

In the previous chapter, I discussed many of the common problems found in popular tourism and ecotourism destinations. In this chapter, I have attempted to put forward a description of Gabon and many of the challenges that will have to be confronted if the country is to become one of the world's premier ecotourism destinations. Some of these challenges such as social stratification and a lack of international familiarity are common among Third World tourism destinations. Others, for example 
bushmeat and price gouging, are somewhat unique to Gabon. All of them can and must be dealt with.

The common thread that runs through almost all of the problems discussed in this chapter is the widespread corruption and irresponsibility in Gabon's government. At the local level this corruption has occurred in large part because of lack of authority and structure for confronting various problems such as bushmeat. This lack of structure is particularly bad in rural Gabon, where the need for communal cohesiveness is most vital. This fragmentation can be traced back to Gabon's fairly recent colonial experience. In a sense, the problems that could prevent ecotourism development in Gabon are either directly or indirectly related to the same problems that have prevented other development opportunities. At the base of society, social development needs to occur before the structural system to confront problems like price gauging and the bushmeat trade can be put into place.

As difficult as it may be to develop local social cohesion, it must be done to confront the country's lack of government accountability, which is a major hurdle to ecotourism success. At a February 2005 conservation summit of Central African nations held in Brazzivlle, one representative of Greenpeace summed up the problem with conservation efforts in the Congo Basin: "Poor governance and lack of transparency need to be tackled as a priority to reduce poverty in the Congo Basin and 
protect and manage its forests in a sustainable manner."107 
Notes

${ }^{1}$ Andrew Curry, "J. Michel Fay: He walked clear across Africa's wild heart," U.S. News \& World Report 131, no. 7 (20 August 2001): 60.

2 Deborah A. Behler, "Gabon Raises the Bar: WCS has been instrumental in the recent decision by Gabon to protect an unprecedented portion of its land for wildlife," Wildlife Conservation, November/December 2002, $6-7$.

${ }^{3}$ Laura Tangley, "Portraits in the Wild: In an unexplored region of Africa's Atlantic coast, an innovative photographer captures Gabon's bountiful wildlife," Smithsonian, October 2003, 61 - 62.

${ }^{4}$ Deborah A. Behler, "Gabon Raises the Bar," 6.

5 Samuel Decalo, The Stable Minority: Civilian Rule in Africa, 1960-1990 (London: FAP Books, 1998), 111.

6 Deborah Farmer ed., "A First Look at Logging in Gabon," Global Forest Watch, 2000, http:/ /www.globalforestwatch.org/common/gabon/ english/report.pdf (accessed 9 May 2005), 8.

7 Samuel Decalo, The Stable Minority, 122.

8 Neil Ford, "Gabon: Hard times on the horizon," African Business, no. 293 (December 2003): 48.

9 Ibid.

10 UN Integrated Regional Information Networks, "UN Mediates Dispute Over Corisco Bay Islands," African News, 25 January 2004.

${ }^{11}$ Ibid.

12 Leslie Palti, "The Chronicle Interview," UN Chronicle 41, no. 3 (September-November 2004): 6 - 8.

13 Samuel Decalo, The Stable Minority, 122.

14 David Quammen, "Saving Africa's Eden," National Geographic, September 2003, 59.

15 Ibid., 121. 
16 Neil Ford, "Gabon: Hard times on the horizon," 49.

17 David Quammen, “Saving Africa's Eden,” 59.

18 Ibid.

19 Deborah Farmer ed., "A First Look at Logging in Gabon," 15.

20 Ibid.

${ }^{21}$ David Ndachi Tagne, "Illegal logging denudes Cameroon's forests," Agence France-Presse Wire 4 February 2005.

22 Deborah Farmer ed., "A First Look at Logging in Gabon," 10 - 11.

23 Ibid., 24.

${ }^{24}$ Michael C. Reed, "Gabon: A Neo-Colonial Enclave of Enduring French Interest," The Journal of Modern African Studies 25, no. 2 (June 1987): $283-320$.

25 U.S. Department of State. United States of America, "International Boundary Study: Republic of the Congo (Congo) - Democratic Republic of the Congo (Zaire)," The Geographer office of the Geographer Bureau of Intelligence and Research. September 8, 1979. http://www.law.fsu.edu/library/collection/LimitsinSeas/IBS127.pdf (accessed 7 May 2005), 2.

${ }^{26}$ D.K. Fieldhouse, The Colonial Empires: A Comparative Survey from the Eighteenth Century (New York: Delacorte Press, 1967), 188 - 189.

27 Michael C. Reed, “Gabon,” 288.

28 Ibid., 288 - 289; and Jeremy Rich, "Une Babylone Noire: Interracial Unions in Colonial Libreville, c. 1860-1914," French Colonial History 4 (2003): 145.

${ }^{29}$ Samuel Decalo, The Stable Minority, 125 - 126.

30 Michael C. Reed, “Gabon,” 287.

${ }^{31}$ Douglas A. Yates, The Rentier State in Africa: Oil Rent Dependency \& Neocolonialism in the Republic of Gabon (Trenton, NJ: Africa World Press, 1996), $99-101$.

32 Samuel Decalo, The Stable Minority, 124. 
33 Ibid., 125.

34 Michael C. Reed, “Gabon,” 297.

35 Ibid., 283.

36 Ibid., 286.

37 Samuel Decalo, The Stable Minority, 111.

38 Ibid., 152.

39 Douglas A. Yates, The Rentier State in Africa, 129.

40 Samuel Decalo, The Stable Minority, 165.

41 Ibid., 111.

42 Michael C. Reed, “Gabon,” 283.

43 Christopher J. Gray, "Cultivating Citizenship Through Xenophobia in Gabon, 1960 - 1995," Africa Today 45, no. 3 - 4 (1998): 389 - 409.

44 Nelson N. Messone and Jean-Germain Gros, "The Irony of Wealth: Democratization in Gabon," in Democratization in Late TwentiethCentury Africa: Coping with Uncertainty, ed. Jean-Germain Gros (Westport, CT: Greenwood Press, 1998), 139.

45 Ibid.

46 Ibid., 139 - 144.

47 Ibid., 143.

48 Ibid., 142.

49 Christopher J. Gray, "Cultivating Citizenship.”

50 Ibid.

51 Ibid.

52 Ibid.

53 Michael C. Reed, "Gabon," 303.

54 Ibid. 
55 Christopher J. Gray, "Cultivating Citizenship."

56 Ibid.

57 Ibid.

58 Ibid.

59 U.S. Department of State, "Gabon Human Rights Practices, 1992," Department of State Dispatch 3, no. 00 (March 1993).

60 Christopher J. Gray, "Cultivating Citizenship"; and Divine Koblah and Brahima Ouedraogo, "African-labor: No longer wanted, migrants flee Gabon," IPS-Press Service/Global Information Network, 15 February 1995.

61 "Defence official says remaining illegal residents will be tracked down," BBC Summary of World Broadcasts, 17 February 1995.

62 Christopher J. Gray, "Cultivating Citizenship"; and "Deportation of 639 illegal immigrants said to make 70,000 since mid-February," $B B C$ Summary of World Broadcasts, 5 April 1995.

63 Janet Matthews Information Services. Quest Economics Database, "Country Profile: Gabon," Africa Review World of Information, 26 September 2002.

64 Samuel Decalo, The Stable Minority, 112.

65 Nelson N. Messone and Jean-Germain Gros, "The Irony of Wealth," 136.

66 Janet Matthews Information Services, "Gabon: Country Profile," 26 September 2002.

67 Ibid.

68 Ibid.

${ }^{69}$ Christopher J. Gray, "Cultivating Citizenship."

70 Michael C. Reed, “Gabon,” 285.

71 Douglas A. Yates, The Rentier State in Africa, 95.

72 Christopher J. Gray, "Cultivating Citizenship." 
73 Antoine Lawson, "Rights-Gabon: Caretakers exploiting child laborers," Inter Press Service, 11 April 2002.

74 Jeremy Rich, “Une Babylone Noire,”145.

${ }^{75}$ Chris McGreal. "Aboard the slave ship of despair: Traffickers buying up the young in west Africa." The Guardian, 16 April 2001, 10.

76 Douglas A. Yates, The Rentier State in Africa, $146-147$.

77 Ibid., 119 - 120.

78 Ibid.; and David S. Wilkie et al., "Role of Prices and Wealth in Consumer Demand for Bushmeat in Gabon," Central Africa," Conservation Biology 19, no. 1 (February 2005): 269.

79 David S. Wilkie et al., "Role of Prices and Wealth in Consumer Demand for Bushmeat in Gabon, Central Africa," 269.

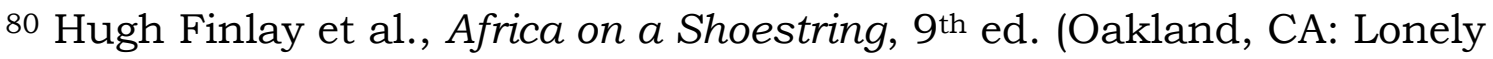
Planet Publications, February 2001), 313.

81 Janet Matthews Information Services. Quest Economics Database, "Gabon: Country Profile," Africa Review World of Information, 23 September 2003; and Brendan Koerner, "Why Does It Cost So Much to Live in Gabon?" Slate Magazine, 16 January 2003, http://slate.msn.com/id/2077091/ (accessed 31 March 2005).

82 Brendan Koerner, "Why Does It Cost So Much to Live in Gabon?

83 Antoine Lawson, "Monkey brains off the menu in Central Africa," Reuters News Service, 1 January 2002.

84 "Ebola Strikes in Gabon," Animal Welfare Institute Quarterly 51, no. 1 (winter 2002).

85 Donald G. McNeil, Jr., "The Great Ape Massacre," The New York Times Magazine, 9 May 1999, 54.

86 Ibid.; and David Quammen, "Almost Cannibalism," The New York Times, 15 June 2003, A16.

87 Donald G. McNeil, Jr., "The Great Ape Massacre."

88 David Quammen, "Almost Cannibalism." 
89 Dale Peterson, Eating Apes (Los Angeles: University of California Press, 2003), 117.

90 "Ebola Strikes in Gabon."

91 John E. Fa and Jessica Meeuwig, "Bushmeat and food security in the Congo Basin: linkages between wildlife and people's future," Environmental Conservation 30, no. 1 (2003): 71-78.

92 David S. Wilkie et al., "Role of Prices and Wealth in Consumer Demand for Bushmeat in Gabon,"273.

93 Dale Peterson, Eating Apes, 116.

94 David Quammen, "Almost Cannibalism."

95 Dale Peterson, Eating Apes, 74.

96 Ibid., 136

97 David Quammen, “Saving Africa's Eden,” 59.

98 John E. Fa and Jessica Meeuwig, "Bushmeat and food security in the Congo Basin."

99 Louis Okamba, "Possible Ebola Outbreak in Congo," Associated Press Wire, 11 June 2002; and "WHO says infected gorilla responsible for lethal Ebola outbreak in Gabon," Associated Press Wire, 10 April 2002.

100 Pierre Rouguet et. al., "Wild Animal Mortality Monitoring and Human Ebola Outbreaks, Gabon and Republic of Congo, 2001 - 2003," Emerging Infectious Diseases 11, no. 2 (February 2005).

101 Dale Peterson, Eating Apes, 85.

102 Antoine Lawson, "Monkey brains off the menu in Central Africa."

103 Dale Peterson, Eating Apes, 260.

104 Donald G. McNeil, Jr., "The Great Ape Massacre”; and Ibid., $91-92$.

105 "Millions pledged to protect Congo Basin," Environmental News Service, 5 September 2002, http://64.233.187.104/search?q=cache:GeR8HwYyJYIJ:ensnewswire.com/ens/sep2002/2002-09-05- 
09.asp+environmental+news+service,+congo+basin,,+ september $+5,+200$ 2\&hl=en (accessed 31 March 2005).

106 "Starbucks president and Congo explorer a winning brew at Seattle event," Conservation Frontlines, winter 2003, 1.

107 Andrew Gray, "Central African Leaders Pledge to Save Forests," Reuters News Wire, 5 February 2005. 


\section{CHAPTER IV}

COSTA RICA: A DEVELOPMENT AND MANAGEMENT CASE STUDY

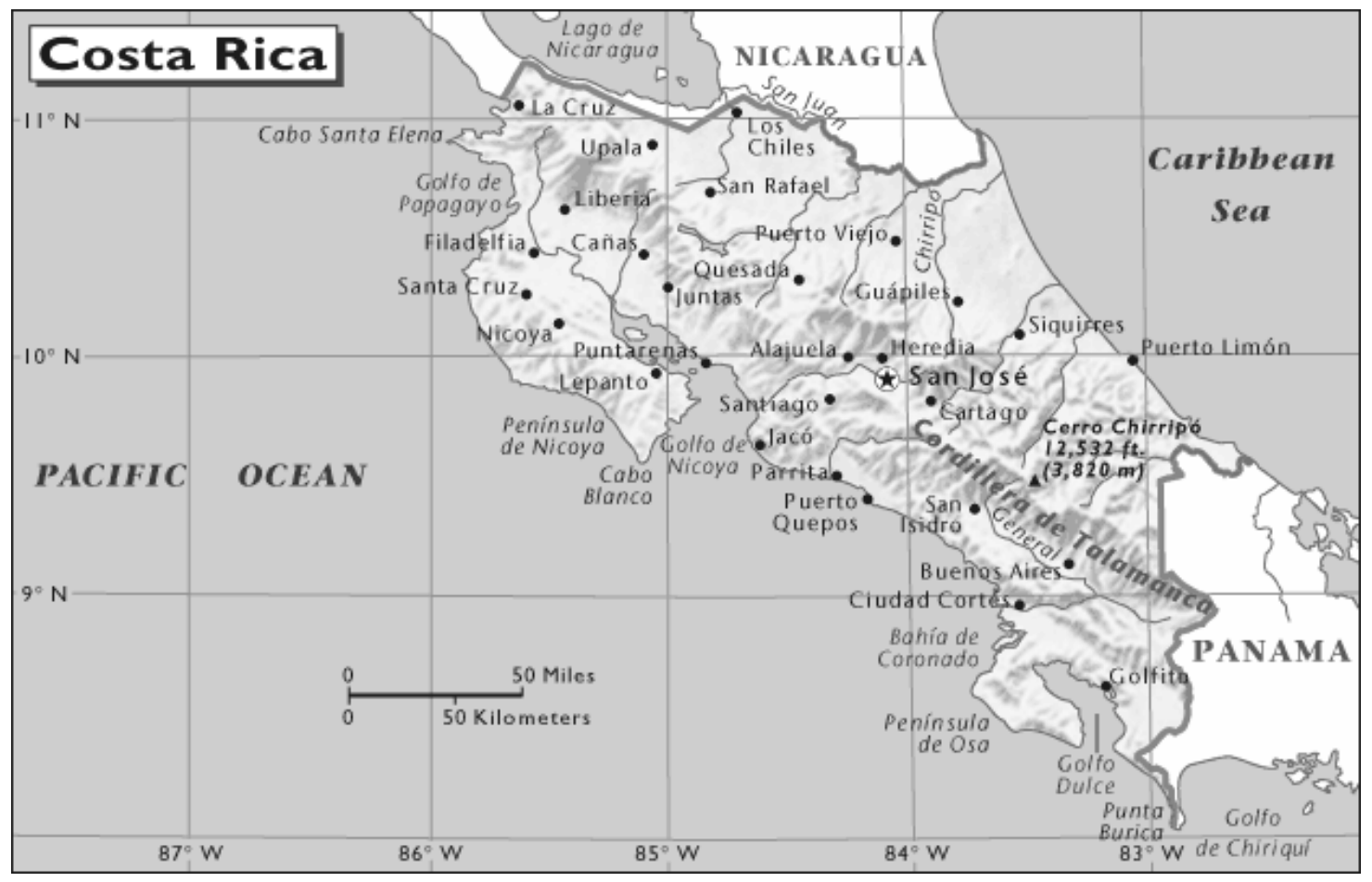

Figure 3. Costa Rica map adapted from Mapquest

No country in the world is more identified with ecotourism than

Costa Rica. ${ }^{1}$ The country's status as the highest-profile ecotourism destination in the world is intimately tied to its well-developed national park system. ${ }^{2}$ If one were looking for a model on which to manage ecotourism in a rainforest environment, Costa Rica would be it. In 1992, the U.S. Adventure Travel Society named Costa Rica the "number one 
ecotourism destination in the world." ${ }^{3}$ In 1993, tourism passed coffee and bananas as the country's top foreign exchange earner. ${ }^{4}$ Yet as recently as the early 1980s, most American travelers knew nothing about Costa Rica, similar to their current understanding of Gabon. Before the mid-1980s, Costa Rica's tourism industry was very modest compared to what it is today. At the time, the country's tourism sector was built mainly on domestic and regional tourism. Most international tourists interested in the Central and South American region visited the Galápagos Islands. By the mid-1990s, however, the number of foreign visitors nearly doubled and gross receipts were up 11-fold. By the year 2000, Costa Rica, a country with a population of only four million, was receiving more than a million visitors a year. ${ }^{5}$ What made this small country the world-leader in ecotourism? As I explain throughout this chapter, there were a number of steps taken by Costa Rica that help to explain the country's success.

The most obvious reason for Costa Rica's ecotourism success is its wide variety of ecotourism activities. While most developing countries offer a small, select choice of environmental tourism experiences, Costa Rica offers something for every imaginable eco-experience. This is because Costa Rica, like Gabon, has such an incredibly diverse environment. At its widest point, the country measures only 297 kilometers from the Pacific to the Atlantic. Because it is mostly coastline, Costa Rica has beaches galore, with plenty of beach activities 
such as surfing and sunbathing. Despite its size, it has the most diverse selection of flora and fauna in the Western hemisphere. ${ }^{6}$ Costa Rica contains roughly 5 percent of the world's biodiversity squeezed into only 0.035 percent of the world's surface area. ${ }^{7}$ For birdwatchers, there are more than 850 species of birds, more than there are in the United States and Canada combined. Of the 330 known species of hummingbirds in the entire world, approximately one-fifth are found in Costa Rica. ${ }^{8}$ There are more than 200 mammal species, including four types of monkeys: howler, spider, white-faced capuchin and squirrel. Costa Rica has a wide variety of reptiles and amphibians, including three types of sea turtles that nest on its shores, two types of crocodiles, and 136 species of snakes. ${ }^{9}$ Costa Rica is also home to more than 9,000 identified species of vascular plants, 6,000 kinds of flowers (including 1,500 varieties of orchids), and more than 35,000 species of insects. Off the country's coasts, visitors can go dolphin and whale watching. Several species of dolphins are visible from both the Atlantic and Pacific coasts. Humpbacks are visible from the Pacific coast, where they come to give birth between mid-December and mid-April. ${ }^{10}$

There are several reasons for Costa Rica's biological diversity. Beatrice Blake and Anne Becher explain some of these reasons in their book The New Key To Costa Rica, now in its seventeenth edition:

Costa Rica's topography ranges from the bleak, treeless paramo, 12,000 feet above sea level, to rainforest on the 
coasts only 50 miles away, with countless microclimates in between. Costa Rica's latitude contributes steady temperatures year-round, and abundant precipitation creates hospitable conditions for many forms of life. Perhaps most important is Costa Rica's position between the Americas: a land bridge between North and South, where migrating animals and plants meet. ${ }^{11}$

Costa Rica's Head Start

When I started the research for this study, I found myself continually turning to Costa Rica for examples of ecotourism management. In many ways, Costa Rica is the perfect model for Gabon to follow. First and foremost among the countries' similarities is their shared environmental composition. When I spoke with anyone involved with ecotourism development in Gabon, Costa Rica was always the ecotourism model cited as Gabon's goal. Gabon is to become Africa's Costa Rica, as was often said.

But if one were to dig beneath the surface of Costa Rica's ecotourism success, he or she would find that it started with some advantages that many developing countries in Africa and Latin America do not have. Ecotourism development has been terrifically successful in Costa Rica, but so have a number of other development initiatives. What separates Costa Rica from a country like Gabon? What advantages did it have for ecotourism development? In later sections of this chapter, I 
provide an analysis of Costa Rica's system as an ecotourism management model. Before I get to this, however, I attempt to explain Costa Rica's path to ecotourism success. Aside from its environmental resources, Costa Rica has a few other ingredients that helped it produce such a successful ecotourism industry. The existence of these ingredients becomes clearer after a brief look at Costa Rica's history.

A History of Costa Rica

Inspect Costa Rica's history and one cannot help but notice a number of differences between it and the history of Gabon. The primary difference in the countries' histories is their colonial experiences. Costa Rica's colonial experience was comparatively brief and much longer ago than Gabon's. For the most part, the overall effort to colonize Costa Rica had negligible success at best; and early attempts at colonization were miserable failures.

There were many reasons why it was difficult to colonize Costa Rica. For one, the country's 25 distinctly different ethnic groups were scattered across the country with no centralized government or ruling authority to conquer. This made it difficult to establish rule over the populations. These tribes were also successful fighters, who were able to battle the colonial forces that attempted to take over the land. The natives were at home in the tropical environment and terrain that was hard for explorers to handle. 
Costa Rica's largest and most developed of these pre-Columbian tribes was the Chorotegas, whose name means "fleeing people." The Chorotegas migrated to the Nicoya Peninsula of Costa Rica roughly a thousand years ago. They were fleeing enemies in Southern Mexico who wanted to enslave them. Fantastic farmers, the Chorotegas introduced cacao to Costa Rica, using its seeds as currency. They successfully grew other crops such as cotton, beans, and varieties of fruits. The concept of community was important to the Chorotegas. A harvest was divided among community members according to need in order for the elderly and widows with children to receive their necessary share. While community was important to them, war was ingrained into their way of life. They kept a permanent military-like organization that fought to obtain land and slaves, who were some times used as human sacrifices to the gods.* Another important pre-Columbian group was the Chibchas, who migrated to the Costa Rican South Pacific from Colombia. The Chibchas lived in well-fortified communities and were constantly embroiled in battles with other tribes for land and slaves. Ancient Costa Rica also had a number of jungle tribes that migrated from modern-day Brazil and Ecuador.

The first European explorer to Costa Rica was Christopher Columbus, who anchored in the Bay of Cariari (now Limón) on

\footnotetext{
* One practice of the Chorotegas was to sacrifice virgins by throwing them into volcano craters, which remains a popular image of ancient Central American cultures that North Americas hold today.
} 
September 18, 1502 after a storm wrecked his ships. This was

Columbus' fourth and last voyage to the New World. The natives greeted Columbus' crew warmly; because of their seemingly gentle nature, Columbus believed they would be easy to conquer. The territory's inhabitants were decked out in gold bands that they wore through their noses and ears, which contributed to the Spanish motivation to colonize the region. The gold the natives wore inspired the Spaniard Gil Gonzalez Davila to name the country Costa Rica, or "rich coast."

As more and more explorers arrived, Costa Rica did eventually become a Spanish colony. In 1562, Juan Vasquez de Coronado founded Cartago, the first successful colonial city. One year later, it was established as the capital of Costa Rica.

Muted Effects of Colonialism

Costa Rica's period of colonial rule was comparatively benign. It was over a much shorter period of time, and the colonizers left much longer ago. The Spanish in essence gave up on Costa Rica very quickly. Of all the Spanish colonies in Central and South America, Costa Rica held the least influence. Initial beliefs that the land had vast amounts of gold and silver proved to be false. There was no exploitable population in Costa Rica, as there was in other Spanish colonies. In Gabon, the French discovered resources to exploit, and were therefore more intent on colonizing the land. 
Costa Rica was also difficult to reach from Guatemala, Spain's seat in its Central American empire. These factors resulted in Spain becoming more interested in developing their holdings in Mexico and Peru. Costa Rica was forgotten, and settlers who came were left largely to their own devices. When Mexico rebelled against Spanish authority, Costa Rica and other colonies followed Mexico's lead. Spain granted independence to its American colonies, including Costa Rica, in 1821, almost 140 years before the French would leave Gabon. This gave Costa Rica a number of years to develop socially and politically, providing a tremendous advantage to later development initiatives.

By the late 1800 s, colonialism had practically come to an end in Latin America. Colonialism, as many authors have previously pointed out, was a means to creating the legal framework and relationships for capitalism to operate. At the end of the nineteenth century, no new colonies were needed in Latin America because a legal system for capitalist trade to continue was already in place. ${ }^{12}$ Because Costa Rica was not subject to harsh colonial rule, it was able to escape the era of colonization without experiencing many of the lingering effects found in other former colonies. Problems commonly associated with colonization, such as large discrepancies between rich and poor, were not as dramatic in Costa Rica; therefore, the country had an edge in post-colonial development. In contrast, Africa had not yet achieved the necessary conditions for capitalist trade by the end of the nineteenth century. ${ }^{13}$ 
Consequently, colonialism continued well into the twentieth century for countries in West and Central Africa.

Democratization and Social Rights

As Martha Honey notes, "Costa Rica illustrates that, most

fundamentally, tourism can only thrive in an atmosphere of peace."14 Unlike most developing countries, Costa Rica has a well-functioning democracy and long-established political stability. In fact, many ecotourism experts point to President Oscar Arias Sanchez's receiving of the Nobel Peace Prize in 1987 as one of, if not the, most important factors in securing Costa Rica's image as a peaceful country and setting it on its way toward becoming the world's most popular ecotourism destination. ${ }^{15}$ Costa Ricans pride themselves on being the freest country in Central America. Political rights and social freedoms are protected in Costa Rica. Freedom House rates the Costa Rican government's position toward political rights as a one, or "free state," its best rating.

Costa Rica's respect for political rights and system of social welfare developed over a number years after it received its independence. The first president of Costa Rica was Juan Mora Fernández. He provided grants to coffee growers, leading to the crop's importance to Costa Rica's development. By the mid-1800s, coffee was the country's major export, and coffee growers became the wealthy elite. ${ }^{16}$ The development of banana plantations in the late 1800s led to the country's next major economic crop. At the turn of the century, small Costa Rica was the 
world's leading banana producer. ${ }^{17}$ In the 1880 s, the government began to distance itself from the more conservative Catholic Church. In 1889 , the first truly democratic election (participated in only by males) took place. Costa Rica's tradition of democracy has carried on till today with only a few exceptions.

In 1940, Rafael Angel Calderón Guardia became president. A deeply religious Catholic, Calderón created many social programs aimed at helping the poor and disenfranchised. Many of these programs such as social security, workers' rights to organize, land reform, minimum wages, and collective bargaining remain today. Unable to hold successive terms as president, Calderón ran Teodoro Picado, a puppet candidate, for president in 1944. Picado won in an election that was criticized as fraudulent. Calderón ran for president again in 1948. The middle class, business people, and young intellectuals opposed Calderón's policies, leading to a civil war during the election.

After the civil war of 1948 , Costa Rica disbanded its army. A new constitution was established in 1949, which formally abolished the army. The constitution also established the right to vote for women and blacks and established a neutral body to oversee elections. The abolition of the army allowed the government to devote more of the national budget to improved education, health care, and the distribution of utilities. In 1986, Oscar Arias Sanchez was elected president. Sanchez campaigned on a promise to work for peace in Central America. As president, he 
stood up to the United States to strictly enforce Costa Rica's

neutrality policy during the U.S. government's support of the Contras in Nicaragua. His actions earned him the Nobel Peace Prize.

Costa Rica Today

Today Costa Rica stands as Central America's development success story. As Lonely Planet puts it, "Costa Rica is Central America's jewel. It is an oasis of calm among its turbulent neighbors and an ecotourism heaven, making it one of the best places to experience the tropics with minimal impact."18 In a country slightly smaller than West Virginia, Costa Rica holds a population of roughly 4 million people. Whites of Spanish descent make up about 94 percent of the population. There is a small black population, which is about 3 percent. Three quarters of the population is Catholic and approximately 14 percent is Evangelical.

The country does not tend to suffer from the social ailments of most developing countries. It has a high standard of living, a large middle class, and one of the best public education systems in Latin America. Infant mortality rates are about 10 per 1,000 live births, much lower than Gabon's. Life expectancy in Costa Rica is 77 years, the same as the United States. (In Gabon, life expectancy is 50.) Health problems such as AIDS and malaria that are substantial in Gabon are minor to hardly existent in Costa Rica. In fact, malaria only occurs in vary 
isolated areas of the country, mainly banana plantations, according to the Costa Rican Ministry of Health. ${ }^{19}$

Poverty has been substantially reduced over the past 15 years, in large part because of government-run social programs. Roughly 90 percent of the population in Costa Rica is literate, the highest literacy rate in Latin America. Literacy rates in Gabon are much lower: 74 percent for men and 53 percent for women. ${ }^{20}$ Economically speaking, Costa Rica has more than just ecotourism going for it. Foreign investors are attracted to Costa Rica because of its political stability and emphasis on education. As a result, the country has gone high-tech. Its reputation for having a well-educated population helped it to convince the computer software company Intel to open a more than 37,000 -square meter manufacturing plant in April 1998, which quickly became the country's number one exporter. The country's strong labor laws have meant reasonable jobs compared to the sweatshops that NAFTA has produced in Mexican border towns. ${ }^{21}$ Unemployment is relatively low. According to the CIA's World Fact Book, unemployment was 6.7 percent last yearnot much higher than the United States. By comparison, Gabon's unemployment rate hovers around 20 percent.

Ecotourism's Development and Management Model Respect for political rights, a strong middle class, an educated population, and initiatives aimed at aiding the poor are all important factors that go into making Costa Rica a successful ecotourism model. 
But of course, there are a few ingredients that are more directly tied to tourism and conservation that are essential. Costa Rica has effectively produced an outstanding collection of scientists and conservationists that work to maintain their system. In addition, hundreds of local and international NGOs have in-country branches. ${ }^{22}$ Costa Rica also has the necessary infrastructure for success. Transportation is easy, with plenty of paved roads and regular domestic and international flights. In the 1990s, the government passed legislation to provide incentives to investors and to improve ports, airports, and street signs. ${ }^{23}$

Much like its promotion of democratic values, Costa Rica also has a long history of public efforts to protect its environment. Conservation legislation in Costa Rica can be traced back to 1775, when Spanish colonial governor Don Juan Fernandez de Bobadilla issued a proclamation against burning fields and forests because the practice caused the soil to become sterile. In the early twentieth century, there was a flood of legislation to prevent wildlife destruction, water pollution, and soil erosion. As early as 1939, Costa Rica was attempting to establish national parks. ${ }^{24}$ Many of these efforts to protect the country's tropical environment were unsuccessful. In the early half of the twentieth century, Costa Rica had the highest deforestation rate in Latin America, mainly due to burning to create pasture for the agricultural industry. Yet beginning in the 1960s, Costa Rica was able to reverse this 
practice with the successful development of its world-renowned national park system. ${ }^{25}$

The first step toward bucking the trend of deforestation for Costa Rica was the creation of Cabo Blanco wildlife reserve, the country's first modern park. David Rains explains the significance of Cabo Blanco in his book The Quetzal and the Macaw:

The problems with the "paper parks" of the 1940s and 1950s (indeed, with virtually all Costa Rican conservation legislation) had been that the government either didn't have or didn't allocate the money to establish, enforce, and maintain the parks. Laws notwithstanding, the volcanoes had been cleared for cow pasture and the oak forests had been cut and shipped to Spain to make wine barrels. Cabo Blanco set a legal and financial precedent that encouraged the government to take action. ${ }^{26}$

Simply put, the government finally started funding all its efforts to protect the country's environment. For some national parks, the government used many of the same approaches as the United State's 1930s New Deal projects, such as the Civilian Conservation Corps and Resettlement Administration. The government paid squatters and farmers who were living on public land to relocate. It created programs for training farmers to use more environmentally sound agricultural practices, and put many relocated individuals to work creating new 
parks. The government's increased role in education and social welfare programs also aided in the success of these new conservation efforts. The growing educational system, in particular, played a pivotal role in establishing Costa Rica's park system. Often university researchers were the source of new ideas or proposals that eventually became legislation. In 1969, when the government created the new park system and placed the park service under the Agriculture Ministry, the park service's first director was a recent university graduate who had proposed a plan to improve one of the old "paper parks" as his master's degree thesis. ${ }^{27}$ The government was able to pay for many of these programs as a result of the abolition of the armed forces after the social and political upheavals of the 1930s and 1940s.

The pro-park movement of the late 1960s also utilized national and local media outlets as a tool to build grassroots support for the development of national parks. Supporters of the park system went on such an all-out media blitz that they, as Rains puts it, seem "to have caught potential park enemies off guard." 28 Campaign organizers would submit articles to newspapers daily, often recruiting Peace Corps volunteers to write them. They frequently took out full-page ads in local newspapers in support of a specific locale being turned into a park; and they took almost every opportunity to cozy up to journalists, offering them personal tours of proposed park sites. 
Without a doubt, the backbone of Costa Rica's entire ecotourism operation is its large collection of national and privately owned parks. Costa Rica's park system is a prime example that the goals of forest conservation can be achieved even in the face of economic problems and a rapidly growing population. Recognized by ecologist Peter Raven as "one of the greatest accomplishments of the human race over the last thirty years," 29 Costa Rica's national park system was officially created in 1969. By 1990, there were 230 different protected areas in Costa Rica. Today, some 13 percent of Costa Rica is under control of the national parks, and as much as 25 percent of the country's territory is under some form of protection. The worldwide average for protected territories is about 3 percent per country. ${ }^{30}$ Approximately half of Costa Rica's protected lands are strictly protected. ${ }^{31}$ These protected areas fall into eight categories, ranging from completely protected to areas where controlled development and extraction are permitted. Government surveys show that most people who travel to Costa Rica are motivated by ecotourism, and many report visiting at least one of the country's national parks, if not another ecotourism facility, during their stay. ${ }^{32}$

The original purpose of the park system was to preserve the country's unique environment for posterity and scientific purposes. Parks were not viewed as sources of public recreation; therefore, tourism dollars were not considered to create and maintain them. In the 1980s, 
however, a severe economic crisis forced the park service to seek funding from other sources, mainly U.S. environmental NGOs and foundations and later other foreign governments. In the 1990s, faced once again with decreasing sources of funding (partly because donors began to lose interest in conservation in Costa Rica), the government for the first time turned to tourism to provide the financial support necessary to maintain the parks. ${ }^{33}$

In August 1994, the government enacted a steep increase in park entrance fees for foreigners, from about \$1 US (the price paid for both domestic and international visitors) to $\$ 15$ at the gate and $\$ 10$ for advance purchase. Bulk purchase prices for travel companies were about $\$ 5.25$. In only the first nine months of 1995 , despite a considerable drop in the number of foreign tourists visiting the parks, the new entrance fees netted the government more than four times what the old fees did in all of the previous year. After much criticism, entrance fees were lowered to only $\$ 6$ for foreign visitors in 1996 . Under this new plan, 75 percent of an entrance fee would go the operating budget of the park or conservation area and 25 percent would support areas where tourism income was low. Foreign donors, both private and public, still provide modest support. ${ }^{34}$ In some cases, these fees are not even used for park management but are diverted to other social needs such as hospitals. ${ }^{35}$ 
Developing Support for Conservation

Costa Rica has a history of supporting conservation initiatives in large part because the social unity and political development necessary to create large-scale support for such initiatives exists. As Costa Rica lacks the social fragmentation of a country like Gabon, grassroots movements for ecotourism development were much easier to establish. An example of one such grassroots movement is the story behind the creation of Manuel Antonio National Park. The movement to establish Manuel Antonio stemmed from a shared desire by locals to preserve the area and an ability to utilize all the skills and assets with which the community had to work.

Authors John Kretzmann and John McKnight are well-known advocates of the assets-based community development model. In the traditional, what they refer to as the needs-based, approach, locals are often seen as powerless or lacking the proper tools necessary to fight against those social forces that prevent positive development. In the traditional model, aid groups seek to fill the gap or provide the missing components necessary for locals to pull themselves up. The assetsbased model insists on starting with a clear commitment to discovering the locals' strengths and assets. This path emphasizes the implementation of policies based on the skills and assets of those within the community toward the goals they have identified for themselves. As Kretzmann and McKnight explain, "historical evidence indicates that 
significant community development takes place only when local community people are committed to investing themselves and their resources in the effort." 36

During the process of creating Manuel Antonio National Park, it was the locals who were quick to point out the problem, which started in 1939. Technically all beaches in Costa Rica are supposed to be public property under law, but Manuel Antonio (named for a conquistador buried in the area) was one of only three private beaches in the country. In 1939, the government foolishly traded Manuel Antonio to the American company United Fruit. Having no use for what is arguably the most beautiful beach in all of Costa Rica, United Fruit sold the land to a wealth Costa Rican, who in turn sold it to a Canadian in 1967. 37 When outside developers closed off the area to visitors and began building on the beach, thousands of local residents and many representatives of international NGOs rallied around the cause of protecting Manuel Antonio. Locals organized letter-writing campaigns to newspapers; activists, including many students, protested businesses attempting to make any changes to the beach; they organized town-hall meetings to discuss new strategies to confront developers. Even when developers tried to lock out protesters by putting up fences, they simply utilized some of the monkey-wrench-gang tactics described by environmental author Edward Abbey by cutting down the fences with pliers. Their work was able to convince the government to raise the 
money to buy back Manual Antonio and establish the territory as a national park in 1972.38 Building such popular support for ecotourism development will be necessary if Gabon's parks are going to succeed.

The Successful Management Model

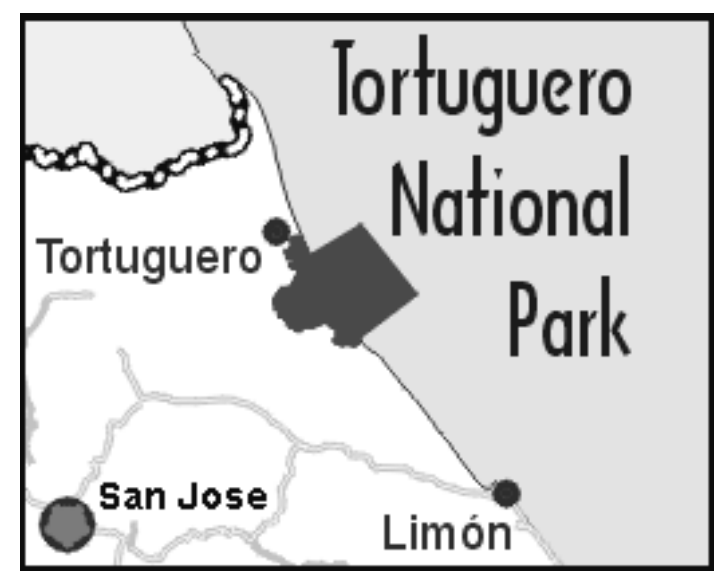

Figure 4. Tortuguero National Park map adapted from Costa Rica Map and Travel Guide website

Currently there are 32 national parks in Costa Rica. One of the most successful and well known is Tortuguero National Park, which extends north along the coast for 22 kilometers from Jaloba to Tortuguero village. Tortuguero, most frequently cited as the example where a national park and ecotourism have worked together to benefit both the cause of conservation and the economic development of the surrounding community, ${ }^{39}$ is a textbook model of national park management and development. Tortuguero protects a unique series of natural inland waterways that are home to freshwater turtles, river otters, crocodiles, manatees, and sloths. The area is also where one can 
find three of the four species of monkeys native to Costa Rica: howlers, spiders, and white-throated capuchins.

Most importantly, Tortuguero is known as the largest nesting area in the Western Hemisphere for the green sea turtle. ${ }^{40}$ These turtles return to Tortuguero every two to four years to mate offshore and dig their nests. Although they can travel thousands of miles away, none of the 30,000 turtles tagged in Tortuguero has ever been found to mate at any other beach. ${ }^{41}$ Tortuguero is the premier center for turtle research in the world. Conservation organizations such as the Caribbean Conservation Corp. (CCC), which started research in Tortuguero in 1954, have greatly advanced the knowledge of the green see turtles. The CCC has built a biological field station and a National History Visitors Center in Tortuguero village, which features videos, pictures, and other information to educate visitors about the turtles. Despite all the work being done by conservation groups, estimates suggest poachers still take 80 percent of the turtle eggs in the area ${ }^{42}$; but the loss would be much greater if not for the park service and conservation groups. And reported incidents of poaching have dropped dramatically in recent years. ${ }^{43}$

Tortuguero National Park succeeds because it keeps its operation small. From what I have found, one of the surest ways to fail to reach conservation and economic development goals with ecotourism is to get too big. Big ecotourism initiatives often have disastrous environmental effects and provide little benefit for locals. The only way to get to 
Tortuguero is by boat, in river taxis for tourists and wealthier Costa Ricans and canoes for the majority of local residents. The absence of roads prevents mass tourism. Visitors are encouraged to carry out all the trash that they bring into the park. During turtle walks on the beach, visitors are not allowed on the nesting sector without a guide after 6 p.m. Only 400 people are allowed on the beach per night, and they are apportioned by sector. There is a maximum of 200 visitors for every two hours.

Local entrepreneurs have also benefited from ecotourism in Tortuguero by starting water taxi services, working as trained tour guides, or managing hotels. As with other national park territories, many locals have been forced to deal with the changing market, especially those whose farms were located within the park and have been bought out by the park service. NGO conservationists state, however, that most local people recognize the economic value in protecting Tortuguero's wildlife. ${ }^{44}$ "Ecotourism has brought a 100-percent improvement to people in Tortuguero, and I've seen a change in mentality as well," said the owner of a tour boat operation. "People now see that through conservation they realize more income."45 From 1986 to 1991, the average income of locals doubled and the number of people working in the tourism field increased from 20 to 70 percent. 46

There are concerns in Tortuguero. Rapid growth is an environmental and economic threat. An influx of tourists brings 
pollution damaging the environment and disrupting the wildlife's habitat and behavior pattern. Locally owned operations are also not able to keep up with rapid growth, creating a market for large, international operations that do not benefit the local population. Currently, hotel and tour operators are fighting a proposed highway sponsored by banana and logging interests into the region between Tortuguero and Barra del Colorado. Still, overall, Tortuguero is judged to be a success for both conservation and economic development.

The True Eco-experience

Right next to Tortuguero National Park is Tortuga Lodge, run by Costa Rica Expeditions (CRE). CRE is a model of an environmentally and socially conscious business venture. Still operating more than a quarter century after the company was started, CRE proves that the goals of economic development and environmental conservation are simultaneously attainable. The company follows the creed, "if tourism does not contribute to protection of flora and fauna, the prevention and repair of environmental degradation, the economic well-being of local communities, and respect for local cultures, it is not a justifiable activity." 47 Tortuga Lodge, situated on 50 acres of private land near Tortuguero, uses solar energy systems and water-conserving fixtures. More than 80 percent of the hotel's employees are from Tortuguero or the surrounding area. CRE pursues the goals of conservation with more than just environmentally friendly lodging. It has donated thousands to 
the various conservation causes such as the Costa Rica National Park Foundation, has trained many locals as naturalist field guides, and supported research to protect animals such as the squirrel monkey. It has also actively campaigned to prevent unsound development, such as the proposed road into Tortuguero National Park. ${ }^{48} \mathrm{CRE}$ is an ecotourism venture done right.

Not All Good News in Paradise

Despite its success at generating national revenue and improving Costa Rica's international image, there are a number of problems with the country's ecotourism industry. Deforestation continues, and the country has few answers to the problem other than to establish parks or protected territories. Outside its parks, the country still has the highest rate of deforestation in Latin America. ${ }^{49}$ With a few exceptions, most of country's national parks are insufficiently funded and are unable to balance their books or make necessary infrastructural improvements on the basis of entrance fees alone. Many parks lack trained naturalist guides or other personnel. And while some parks are isolated and difficult to reach, therefore, receiving few visitors, others have suffered environmental damage because of a flood of tourists.

\section{Under Developed}

One common problem with a number of Costa Rica's parks is the underdevelopment of the tools necessary for proper management. One example of this is Braulio Carrilo National Park. When it was created, it 
was believed that Braulio Carrilo would become one of the most popular parks in all of Costa Rica. As you see below, however, the park has not lived up to it potential as a popular destination. At 44,099 hectares, Braulio Carrillo is rarely visited. Despite its location only 30 minutes from San José, Braulio Carrillo is one of the least visited parks in the country. It was created in 1978 as the result of a compromise between development advocates and environmentalists, who were concerned about the opening of the Guápiles Highway. The park is home to 600 identified species of trees, more than 500 species of birds, and 135 species of mammals, including howler and capuchin monkeys. Because of its location and accessibility, many involved with the development of the park believed that it would be "the most highly used" in the country once it was open. ${ }^{50}$ The park has yet to live up to expectations because of a lack of infrastructure. By 1990, the only amenities the park service had provided at Braulio Carrillo were a small ranger station, a visitor center at a pull-off, and an unpaved, unlandscaped picnic area. ${ }^{51}$ The park's paths are in notoriously poor condition. The common complaints are that they are too small or unkempt. Unfortunately the park service staff just does not have the personnel to take care of most of the park. "Braulio Carrillo may be one of the most interesting parks in the world," a University of Costa Rica professor is quoted as saying, "(it is) totally unknown even though (it is 
only) a half-hour away from a big city." 52 The tourism development and outreach efforts of Braulio Carrillo have been essentially nonexistent.

Braulio Carrillo is not unique. Many parks lack visitor centers or trained guides, and many have no hotels or restaurants around them. Because of various financial pressures, the government has struggled to find the funds to continue basic operations at many parks, much less create new infrastructure at under-visited parks. Some of these financial problems stem from polices of the IMF and the World Bank. But financial problems have also been caused by the government's overreliance on development funds from international NGOs that, for a while, lavishly donated to Costa Rica's conservation efforts. Once many of these NGOs became bored with Costa Rica and went in search of new projects, the government found itself struggling to maintain some parks.

\section{Overly Developed}

Earlier I discussed the success of locals in creating Manual Antonio National Park. Manual Antonio is unusual in that it is an example of what to and not to do. The movement to create Manual Antonio is inspiring and a positive example to follow. Ironically, local residents and conservationists have been less successful at preventing foreign, destructive development on the beaches of Manual Antonio since it became a national park. The park suffers largely because it is opposite of Braulio Carrillo on the popularity spectrum. While it is one of the 
smallest parks in the country, it is also one of the most popular destinations in Costa Rica.

At 628 hectares, small Manuel Antonio National Park has suffered because of overuse. Visitors are guaranteed close encounters with monkeys, sloths, coatimundis, and scarlet macaws. But rapid, uncontrolled growth is threatening the wildlife and environment. Roads into the park have enabled the construction of hotels, restaurants, bars, nightclubs, and even casinos around the park in recent years. Because areas around the park lack proper sewage systems, waste is dumped directly into the sea. ${ }^{53}$ Manuel Antonio is one of the few remaining habitats for the mono tití, or squirrel monkey. There are only an estimated 3,500 squirrel monkeys left, down from an estimated 200,000 as recently as 1983.54 One of the main causes of death for these monkeys has been electrocution from the number of electric lines serving power to buildings. Visitors also feed the monkeys, despite warnings of the illegality of the activity, and leave food lying around for monkeys to steal. Human food is not good for these animals, as monkeys are much more susceptible to heart disease. Some recent studies have actually shown an increase in heart failure in the monkey population. ${ }^{55}$ Garbage brought in from outside the park has also increased the raccoon population in the park. At times, the number of raccoons has become so large that they threaten the populations of herons and hawks, which compete with the raccoons for crabs and other natural foods. 56 
The overdevelopment problems at Manuel Antonio can be found all over the country, but they are especially bad along Costa Rica's Pacific coast where Antonio is located. A detailed1996 study by Becher of hotels along the Pacific coast found that the majority (57 percent) of hotels and resorts were owned by foreigners. According to the study, foreign investment is most common along the most famous and frequently visited beaches, whereas locally owned hotels-which are most popular with Costa Ricans-are usually forced to locate on the least desirable beaches. ${ }^{57}$ These large foreign resorts not only do a great deal of damage to the environment, but they have also helped to create a sense of cultural alienation between Costa Ricans and their own land. Because these large resorts are expensive, they are usually out of the financial reach of Costa Rican visitors. The cost of living along Costa Rica's beaches has skyrocketed, causing few locals to reside in these territories any more. As a result, English is spoken more often than Spanish around these resorts, and many Costa Ricans feel resentment at not being able to benefit from their country's beaches. Technically there are regulations in place to prevent foreigners from operating hotels on the country's beachfronts. Foreigners are not supposed to be able to obtain concessions to build within 200 meters of the beach without living in Costa Rica for at least 5 years. Foreign developers get around this rule, however, by applying for concessions in the name of Costa Rican partners. 58 
The majority of hotels in Costa Rica are small, with 16 rooms or fewer, 59 but the number of large resorts is on the rise. These large resorts not only take revenue from local hotel owners, but they also hurt other local businesses. Visitors to these resorts can find everything they need during without even having to step outside the building. Resorts offer stores that provide all possibly needed supplies, restaurants that visitors often believe provide authentic local cuisine, and even souvenir shops. Of course, visitors who stay in these large resorts are not having a genuine ecotourism or cultural experience, but even those who realize that do not often care. Large resorts offer foreign visitors a sense of comfort. Guests can book their rooms over the web easier with large resorts. They can feel safe and secure and find everything they need without once having to go through the trouble of understanding a foreign language.

The country's tax system is unintentionally skewed to favor the creation of large resorts instead of small, environmentally friendly lodges that are usually owned and operated by locals. The Instituto Costarricense de Turismo (ICT), the country's tourism board, created tax breaks to encourage development of new tourism-related facilities. In a study for the New Key to Costa Rica, Becher and researcher Jane Segleau found that smaller hotels and resorts do a better job of conserving and protecting the environment; yet, 60 percent of the operations that they recognized as being more environmentally friendly were too small to 
qualify for tax incentives. ${ }^{60}$ After complaints that these breaks were only going to large resorts, the ICT modified regulations to allow lodges with as few as 10 (instead of 20) rooms to qualify for incentives. But to qualify for these incentives, one needs a tourism contract, which entails getting consultants and developing feasibility studies, things that small, local business owners are unable to afford.

\section{Private Reserves}

Increasingly many visitors are flocking to Costa Rica's hundreds of private land reserves. These private reserves, which have been around even longer than the country's national park system, shot up in number from the 1980 s to the mid-1990s. They are now estimated to cover 2 to 5 percent of Costa Rica. These reserves come in all shapes and sizes and are created for a number of different reasons. Some are owned by international conservation NGOs. Many are involved with ecotourism. These reserve are eligible for some governmental support. If they register with the government, they receive a package of benefits, including certain tax exemptions and technical assistance with projects. The government also promises to remove all squatters within three days. ${ }^{61}$ Many of these private reserves are located next to national parks. These private reserves have had limited success. Private reserves are often better able to provide an authentic ecotourism experience and better protect the environment. Their successes in these areas are due in large part to the fact that they can hire the best guides and scientists, and-because they 
often charge a pretty penny-they can cater to the most elite of visitors. The government often encourages the creation of these reserves. The belief is that private reserves can afford to protect the land and provide services that the government cannot. They are able to avoid all the red tape that goes into establishing a national park and can respond to needs much quicker than state-run parks. ${ }^{62}$

A drawback to these reserves is that they often piggyback on the work of the government and the park service to turn an area into tourist attraction without returning support to the national parks. A prime example of this problem is Rain Forest Aerial Tram, a state-of-the-art ecotourism operation that shares a 10-kilometer border with Braulio Carrillo National Park. RAFT offers visitors a bird's eye view of the rainforest by lifting tourists 30 meters into the air for a 1.3-kilometer trip. While Braulio Carrillo receives few visitors, the small 1,000-acre RAFT generates profits, mainly because it can charge tourists a minimum of $\$ 49.50$ US per day for access to the park. The company's deluxe package for overnight guests, which includes meals, costs $\$ 78.50$ per person per day. RAFT has experienced such success it now has three locations: an additional one in Costa Rica and one in the Dominican Republic. While often successful, most private reserves are small compared to national parks and are not able to protect the most environmentally important territories. The rising number of these reserves has forced the park service to compete for NGO funds, 
scientists, and most importantly tourists. National parks struggle to compete for tourists because private reserves are able to provide amenities that national parks cannot. 63

Some conservationists have rightly worried that too much optimism has been placed on the ability of private reserves to protect the environment and contribute to local economies. In the future, the government needs to put additional pressure on these reserves to work more closely with state institutions, such as national parks and universities. With the current political climate in the United States, there has been an increasing push by groups on the political right to privatize all conservation efforts such as national park and forests. While a similar push is unlikely to gain much steam in Costa Rica, if private reserves continue to rise in profitability and popularity in comparison to national parks, there will be efforts to shift more state resources and attention to private reserves at the expense of public parks. This would be an enormous mistake. Given their usual size, private reserves are not capable of conservation on the scale of national parks. They are not subject to the same environmental protection requirements that government-run and operated territories are; and because of the prices they charge, they are inaccessible to the overwhelming majority of Costa Ricans. Private reserves have a role in a country's ecotourism industry: a supporting role. 
The Problems With Packages

In regard to the concern of tourism leakage, explained in chapter 2, Costa Rica has been relatively successful at developing a system where tourism dollars benefit its population. Only 45 percent of tourism spending filters its way outside of the country, a significantly lower percentage than other Third World tourism destinations. ${ }^{64}$ One reason for the lower level of leakage is that Costa Rica has done a good job of turning out its own educated population to serve as tour guides, hotel managers, park administrators, and in other tourism-related roles. The country also benefits from having a well-earned reputation as an ecotourism destination, which means travel organizations do not have to market it as much as other destinations. Nevertheless, in recent years there has been a sharp rise in the number of tourists visiting Costa Rica though prepaid travel packages and cruises. Very little of the money from these packages stays in and benefits the local economy. Stopping this trend of prepaid travel packages is an important concern for Costa Rica's tourism industry.

The Ecotourism Yellow Brick Road

Costa Rica is a model for ecotourism development in a number of ways. Obviously it is an example of a successful ecotourism destination. But beyond this, an examination of Costa Rica helps to clearly illustrate the ingredients of ecotourism development that Gabon lacks and provides examples of positive and negative management styles. First, a 
comparison of the country's history to that of Gabon's explains why development initiatives in general have been more successful. Costa Rica lacked the political fragmentation of Gabon, and therefore, was able to build the popular support for a number of movements, including its conservation initiatives. Gabon will have to replace much of its social division with the popular support for conservation in order to achieve ecotourism success. Second, Costa Rica provides examples of how to and how not to manage ecotourism development once it has been created. While Costa Rica has made mistakes, many of these are the result of having few ecotourism models to follow itself. All things considered, Costa Rica is Gabon's yellow brick road to follow toward ecotourism development. 
Notes

${ }^{1}$ Martha Honey, Ecotourism and Sustainable Development: Who Owns Paradise? Washington, D.C.: Island Press, 1999), 131.

2 David B. Weaver and Regina Schlüter, "Latin America and the Caribbean," in The Encyclopedia of Ecotourism, ed. David B. Weaver (London: CABI Publishing, 2000), 177.

3 Martha Honey, Ecotourism and Sustainable Development, 131.

4 Martha Honey, "Giving a Grade to Costa Rica's Green Tourism," NACLA Report on the Americas 36, no. 6 (1 May 2003): 39 - 46.

5 Ibid.

6 Beatrice Blake and Anne Becher, The New Key To Costa Rica, 17th ed. (Berkeley, CA: Ulysses, 2002), 16.

${ }^{7}$ Martha Honey, Ecotourism and Sustainable Development, 132.

${ }^{8}$ Beatrice Blake and Anne Becher, The New Key to Costa Rica, 25.

${ }^{9}$ Ibid., $22-23$.

10 Ibid., $27-28$.

${ }^{11}$ Ibid., 16.

12 Edward Goldsmith, "Development as Colonialism," in The Case Against the Global Economy: And for a Turn to the Local, ed. Jerry Mander and Edward Goldsmith (San Francisco, CA: Sierra Club Books, 1996), 255.

13 Ibid.

${ }^{14}$ Martha Honey, "Giving a Grade to Costa Rica's Green Tourism."

15 Authors who have pointed to the significance of Arias' Nobel Prize include the following: Martha Honey, Ecotourism and Sustainable Development, 131; David B. Weaver and Regina Schlüter, "Latin America and the Caribbean," 177; and Frank Graham, Jr., "Rainforest TV," Audubon 92 (November 1990): 22-23.

16 Beatrice Blake and Anne Becher, The New Key to Costa Rica, 4. 
17 Ibid., 9.

18 "Costa Rica," Lonely Planet, http://www.lonelyplanet.com/destinations/central_america/costa_rica / (accessed 6 April 2005).

19 Beatrice Blake and Anne Becher, The New Key to Costa Rica, 56.

20 Janet Matthews Information Services. Quest Economics Database, "Gabon: Country Profile," Africa Review World of Information (23 September 2003).

${ }^{21}$ Beatrice Blake and Anne Becher, The New Key to Costa Rica, 13

22 Martha Honey, Ecotourism and Sustainable Development, 132.

${ }^{23}$ Ibid., 135.

${ }^{24}$ David Rains Wallace, The Quetzal and the Macaw: The Story of Costa Rica's National Parks (San Francisco, CA: Sierra Club Books, 1992), 11 -12 .

25 Ibid., xv.

26 Ibid., 13.

27 Ibid., 15.

28 Ibid., 36.

${ }^{29}$ Ibid., xvi.

30 Martha Honey, "Giving a Grade to Costa Rica's Green Tourism."

${ }^{31}$ David B. Weaver and Regina Schlüter, "Latin America and the Caribbean," 177.

32 Martha Honey, "Giving a Grade to Costa Rica's Green Tourism."

${ }^{33}$ Martha Honey, Ecotourism and Sustainable Development, 140 - 141.

34 Ibid.

35 Stephen Wearing, "Exploring Socio-cultural Impacts on Local Communities," in The Encyclopedia of Ecotourism, ed. David B. Weaver (London: CABI Publishing, 2000), 397. 
36 John Kretzmann and John McKnight, "Assets-based Community Development," National Civic Review 85, no. 4 (winter 96).

37 David Rains Wallace, The Quetzal and the Macaw, 46 - 49.

38 Ibid., $46-49$.

39 Martha Honey, Ecotourism and Sustainable Development, 146.

40 Beatrice Blake and Anne Becher, The New Key to Costa Rica, 214.

${ }^{41}$ Ibid.

42 Ibid.

43 "Tortuguero National Park," CentralAmerica.com, http://centralamerica.com/cr/parks/motortuguero.htm (accessed 6 April 2005).

${ }^{44}$ Martha Honey, Ecotourism and Sustainable Development, 148.

45 Ibid., 147.

46 Ibid.

47 Ralf Buckley, Case Studies in Ecotourism (Cambridge, MA: CABI Publishing, 2003), 137.

48 Ibid.

49 Ibid., 142.

50 David Rains Wallace, The Quetzal and the Macaw, 80.

${ }^{51}$ Ibid., 94.

52 Ibid., 81.

${ }^{53}$ Martha Honey, Ecotourism and Sustainable Development, 142.

54 Beatrice Blake and Anne Becher, The New Key to Costa Rica, 409.

55 "Manuel Antonio National Park," CentralAmerica.com, http://centralamerica.com/cr/parks/momanuelantonio.htm (accessed 6 April 2005). 
56 David Rains Wallace, The Quetzal and the Macaw, 53.

57 Martha Honey, Ecotourism and Sustainable Development, 136 - 137.

58 Ibid., 137.

59 Ibid., 170

60 Ibid., 138 - 139.

61 Ibid., 150

62 Ibid., 163.

63 Ibid., 164.

${ }^{64}$ Kreg Lindberg, "Economic Impacts," in The Encyclopedia of Ecotourism, ed. David B. Weaver (London: CABI Publishing, 2000), 367. 


\section{CHAPTER V}

\section{CONCLUSION}

The purpose of this study was to examine the possibilities of developing a successful ecotourism industry in Gabon. Throughout the previous chapters, I addressed many of the challenges to ecotourism development that Gabon will confront. It is the conclusion of this study that these obstacles can either be overcome or addressed in such a way that over time Gabon can be able to become a successful ecotourism model. In this chapter, I discuss many of the challenges to ecotourism development. Before I address these challenges, however, let me go back to the four specific questions posed at the beginning of this thesis.

The first question was, "What is ecotourism?" This question was discussed and answered in Chapter II, but here is a quick recap. As described by R.K. Blamey, there are three constant and essential principles of any ecotourism program: (1) that it is nature based, (2) that it is environmentally educated, and (3) that it is managed in a sustainable manner. ${ }^{1}$ The third principle here applies to the sustainability of both the physical and cultural environments of the host country or community. The final, often implied, principle of ecotourism is that ecotourism is meant to "do the right thing" by bettering both the 
natural environment and the lives of members of the host community. Last, while economic development is important, true ecotourism initiatives have the primary objective of conservation of the environment with the secondary objective of profits, which distinguishes ecotourism from typical private business initiatives.

The second question was, "Can ecotourism replace Gabon's timber industry and declining oil revenue?" Like many researchers, I held an opinion on some of my questions before I began my research. Careful not to let my own personal biases unjustifiably influence the outcome of my research, I did not express my opinion on this question at beginning of this study. At the time I began this thesis, I believed ecotourism could easily and quickly replace Gabon's oil and timber revenue. Now, however, I find myself with a new opinion on this question. My conclusion is no. Ecotourism cannot replace Gabon's oil and timber revenues. It can, however, offset the need to increase timber harvesting in the future.

When I posed this question, it was done in the context of explaining Gabon's declining oil revenue and the need to replace this source of income. The country needs alternative revenue sources that can start producing income quickly. I started this thesis believing strongly that ecotourism was the immediate remedy for Gabon's oil troubles. If all that were needed to turn Gabon into a major ecotourism destination were tourists, I might have been right. 
After examining the political and social state of Gabon, I have come to the conclusion that there are simply too many problems within Gabon's society for the type of dramatic development of ecotourism that took place in Costa Rica. Before Gabon can achieve the success of Costa Rica, there will have to be a number of efforts to reverse the lingering effects of colonialism and the continuing exploitation of Gabon's society and resources through colonialism's modern incarnation: globalization. Efforts to overcome the results of colonialism must seek to create positive social capital and political development. Social capital and political development will foster many of the following steps toward ecotourism development, such as producing the popular support for ecotourism initiatives. Discussions of some successful models used to create better social development are explained in the later sections of this chapter.

When I presented my survey questions to Lee White, with the Wildlife Conservation Society (WCS), he gave me a WCS-internal document on ecotourism in Gabon. At the very beginning of the document it said that WCS aims to achieve 100,000 visitors per year and to generate annual tourism revenues of $\$ 500$ million US within the next 10 years. This stated goal is certainly achievable, but I would say it is optimistic. Even if the country were able to attain this goal, however, ecotourism still would come nowhere near replacing the billions of dollars of revenue that oil currently contributes to the economy. The United States alone spent more than $\$ 1.6$ billion on crude oil from 
Gabon in 2002.2 It would be counterproductive to promote ecotourism as the solution for Gabon's economy. A realistic ecotourism growth estimate will better ensure that the public will not turn its back on ecotourism because of early disappointment.

This unfortunately means that the temptation to expand the country's timber concessions will be even greater. The government must resist this temptation. Increasing logging concessions will only serve as a temporary fix-at best. An expanded logging industry will cause Gabon to lose its unique environment and wildlife diversity. Soon Gabon would find itself with no trees to cut down, no oil to dig up, or anything for tourists to come see. Offsetting and eventually replacing Gabon's oil revenue will require the government to take many of the steps that Costa Rica took to eliminate its reliance on environmentally harmful banana farming.

Finally, the third and fourth questions were: third, "What form should ecotourism take in Gabon?" and fourth, "What can be learned from ecotourism programs in other countries to inform Gabon's development of ecotourism?" With these questions, my interests were in explaining the details of a proper approach to establishing ecotourism specifically for Gabon. I wanted to explain some common problems associated with ecotourism destinations and how to avoid them, address how to remedy some issues that are unique to Gabon that could adversely affect the country's efforts, and provide some positive 
ecotourism approaches that Gabon would do well to follow. The answers to various parts of these questions can be found throughout the previous chapters of this thesis. In chapter 2 for example, I explain many of the common problems associated with ecotourism and ways to avoid them. In chapter 3, I address many of the individual problems Gabon will face. And in chapter 4, I present Costa Rica as a model of ecotourism management, with various steps that the Gabonese government, business leaders, and NGOs would be wise to follow. In the rest of this chapter, I pull these lessons together to discuss the challenges to ecotourism development. Some of these challenges will be relatively easy to remedy. Others will likely take years to bring under control. Some are common among most ecotourism destinations. Others apply specifically to Gabon. These challenges and some suggestions on how to approach them are as follows:

\section{Political Development}

The lack of political development within Gabon is likely to be the greatest obstacle to successfully establishing ecotourism. As mentioned in the section of this study on Costa Rica, true ecotourism cannot flourish in an environment where political rights are not respected and corruption is rampant. The obvious reason for this is that visitors tend to stay away from countries that do not respect social freedoms. The other less obvious problem, however, is that the lack of political development within Gabon prevents local communities from confronting 
many of the other issues brought up within this study, including the corruption that surrounds the logging industry and bushmeat trade. The lack of political development is unlikely to be solved in the near future, which is yet another reason that Gabon's hopes to stave off further economic recession should not be pinned on ecotourism. Yet, the situation is not hopeless. There are a number of successful models for addressing the lack of political development in countries similar to Gabon. While a complete description of how to confront this problem cannot be provided in this study, some successful models for addressing these concerns are specifically addressed in the next couple of sections as well as mentioned in other sections of the chapter.

\section{Democracy and political and social rights}

There is little doubt that government abuses of rights and the lack of a functioning democracy are likely to hinder Gabon's ecotourism goals. While it is unlikely that Bongo will resign for Gabon to become a functioning democracy, an aggressive effort by local and international NGOs to promote democratization and the empowerment of vulnerable populations is possible. As Julie Fisher points out, proactive NGOs can further democracy and sustainable development through their relationships and interactions with governments. ${ }^{3}$ One popular and often effective approach to advancing democracy is the use of advocacy. While unlikely to be successful in an extremely oppressive society like North Korea, political advocacy is often successful in a country like 
Gabon. Advocacy does not have to be limited to legal lobbying efforts either. One approach is for NGOs to develop working relationship with parities in opposition to the ruling Gabonese Democratic Party.

Democratization advocacy can also be accomplished without direct interaction with governments. For example, grassroots NGOs have used bottom-up advocacy tactics such as mass protest, strikes, and elections observations to force change. ${ }^{4}$ These types of bottom-up advocacy tactics have been used successfully in the past in Gabon. As mentioned in chapter 3, massive protest in the early 1990s forced a number of election freedoms.

From my work with Destination: Gabon, on occasions I heard reservations from environmentalists about Bongo leaving office because of his support of the country's national park system. These reservations are misguided. Democratic, free societies do much better jobs of environmental protection than dictatorial regimes. In 2004, the Nobel committee brought much-needed attention to the often-overlooked relationship between political rights and environmental conservation when it awarded the Nobel Peace Prize to Kenyan environmental activist Wangari Maathai, who has created a movement to plant millions of trees throughout East and Central Africa. As Maathai has pointed out, a country's ecological state is often a barometer on its national health. ${ }^{5}$ Free elections will help ensure that the Gabonese will be more accepting 
of the country's ecotourism efforts because they had a role in supporting the initiative instead of having it forced on them.

\section{Local empowerment and social stratification}

While Gabon may be economically successful in comparison with most African countries, most of the population receives little if any benefit from the country's wealth. Spurring local, social development is difficult. Academics, NGOs, and international bodies have been arguing amongst themselves for years over how to accomplish this task. One often-mentioned approach by bodies such as the World Bank and IMF is increased government investment in the country's social services such as education. This approach is almost always worth trying. But for a country such as Gabon, approaches such as these have had mixed results at best since most of the agencies in charge of providing these services are often teeming with corruption.

Some NGOs have found success with efforts aimed at creating a certain level of unity between locals, or in a sense, strengthening communities. The need for strengthening communities has often been necessary in places such as francophone Africa, where recent colonial occupations and the expanding power of global companies have contributed to stratified societies. One such model, which has its roots in francophone Africa, is Six-S, short for Se Servir de la Saison Séche en Savane et au Sahel, or Making Use of the Dry Season in the Savannah and the Sahel. Six-S serves as a catalyst to mobilize locals by working 
with community groups to establish their own development activities. The organization does not assist in the formation of groups, but instead cooperates with preexisting ones that follow the traditional patterns of local cooperation. Six-S also does not choose, design, or manage development projects. The organization follows a philosophy that local groups that take these steps on their own maintain greater independence. What Six-S does is offer to fill in the gaps in resources and skills that local residents often encounter as they take on villagelevel development. 6 Only mature groups that have proved themselves financially and managerially responsible can receive funding from Six-S. Even those that do receive funds do not directly receive aid. Six-S funding goes to a federation, which can consist of anywhere between 10 and 50 smaller village groups, that in turn provides money to individual groups. Pressure from the federation makes sure that local groups use the funding wisely and repay debts.

Six-S's aid process develops communities through building and strengthening horizontal relationships. It does this in a couple of ways. First, by working with mature groups that choose and manage their own development projects, Six-S prevents dependency. Second, by relying on social pressure from other village groups to encourage repayment of loans, the program fosters solidarity. Members realize that by working to together to replay the loan they will be able to take advantage of future funds. ${ }^{7}$ 
Another successful approach for easing social stratification is been direct investment in human capital. Investment in human capital is a double positive since human capital is generally the least environmentally destructive form of development. In the last decade and a half, it has been increasingly difficult to tell the difference between environmental and poverty NGOs operating in the Third World. ${ }^{8}$ This is in large part because more development activists have noticed the relationship between the two issues. The popular Green Belt Movement (GBM), for example, established by Maathai, empowers women by teaching them to plant trees. Besides the environmental benefits, more trees mean more firewood for cooking and less time searching for wood allows women to stay closer to home and accomplish other tasks. Women also earn income from sustainable harvesting of fruit and wood from the trees.

\section{Limited Accessibility}

It can be a real headache to get to Gabon and even more of one trying to get around the country. This may be somewhat of a catch 22 . Part of the reason the country's rainforest is so pristine is the difficulty of reaching Gabon and traveling once you get there. For successful ecotourism development, however, a balance must be found between being accessible and preventing massive access to environmentally sensitive areas. After all, Gabon will certainly not make any money on ecotourism if tourists are not able to get into the country or see the sites. 
Direct flights from United States and more of Europe

With the current process of flying from the United States to Paris and then into Libreville, travel to Gabon can be extremely expensive and time consuming. In order to avoid jet lag, some tourists may even be tempted to spend a couple of nights in Paris. A layover in Paris on top of a typical Air France economy ticket, which ranges from $\$ 1,300$ to $\$ 2,500$, makes simply traveling to Gabon out of reach for many travelers. According to the WCS, Libreville's airport cannot have direct flights to or from the United States because of the airport's lower security standards. If this is the case, then the government will have to improve security. The economic return from direct flights would be far greater than the expense of increased security. The government should also look into stimulating competition among airline companies in order to increase the number of carriers traveling to Gabon and reduce ticket prices. In-country travel infrastructure

Paved roads leading into every park is not necessary for improved mobility. Tourists do not need uninhibited access to anywhere in the country they want. But currently it is too difficult for tourists to get around Gabon. Many sites are only accessible through Libreville, which can be a tremendous problem when developing travel itineraries. While I was working with a tour guide in Gabon to create a travel itinerary for birders, we had no other choice than to fly tourists west from Franceville all the way back to Libreville for a one night stay, only to be flown back 
east to Makokou to visit Ivindo National Park. This cost extra time and money. Remedying this problem will require steps such as expanding rail service from Libreville to more than the current small number of destinations and improvement in the poor state of many of the domestic airfields. Planners should also consider creating access between various destinations so travelers do not have to go through Libreville.

Getting visas

The infamously long and irritating process for obtaining a visa must be fixed. Streamlining the visa process would go a long way to promoting tourism. This can be done with steps such as making the paperwork available for tourists to electronically fill out on the web. Eliminating the visa requirement for visitors only staying a few weeks from major tourist markets in North America and Europe should also be considered.

\section{Local Education and Investment}

If the Gabonese are not informed about and invested in the process, a number of problems, including unrealistic expectations and the inability to manage the system, are likely to develop. Educating and developing a stake in the system will help overcome these common problems with Third World tourism. 
The primary goal is preservation, not profit

The primary goal of true ecotourism is preservation, not profit. Since this is the case, as Third World tourism author Deborah McLaren told me, “... then locals need to be included in whatever plan is created and need to be informed from the start that protection of the environment is the primary goal. Local education and training are the most important (steps to prevent unrealistic expectations)." I wholeheartedly agree.

Sustaining the environment

Ecotourism cannot be sustainable if the local community is not involved with the development and planning. It is absolutely vital to invest in the people who will be called upon to defend Gabon's environment in the long term. Studies in Gabon have shown that when efforts are made to reach out to locals, they step up to the plate. One 2001 study in Gabon's Gamba Complex by the World Wildlife Fund sought to measure the perseverance and level of interest of individuals who attended ecological training sessions in the 1990s. The study looked at participants who were trained and put to work conducting various ecological surveys to monitor wildlife and sensitive areas. Subsequent participation of government employees and locals were examined. The results were remarkable. Only 7.7 percent of government employees continued to use ecological surveys two years after their work on monitoring projects. Villagers, however, proved to be an extremely 
sustainable resource, as 76 percent continued to monitor the region's environment a full two years after their training. ${ }^{9}$

Researchers for the study were able to point to the vested interests of locals as the primary reason they were more likely to stay involved. Government employees went back to their original work duties and would not use the skills they acquired at other work sites. Villagers, on the other hand, were eager to participate because of the job related opportunities of learning a new skill and because they were able to work near their place of residence. They also proved useful because of their knowledge of local languages and socioeconomic environments, making it easier for them to establish trust and contacts during surveying projects. ${ }^{10}$

\section{Sustaining culture}

Local involvement is also necessary to prevent local communities from losing their cultural distinctiveness and the rise of problems such as sex tourism. To sustain ecotourism and prevent cultural problems, community leaders and conservationists will have to work with locals to develop strategies on handling and avoiding some common problems associated with tourism. This will require educating the population about issues such as invasion of privacy, tourists traveling into sensitive areas, or tourists approaching locals for sex or drugs. 
Developing local managers

Gabon's ecotourism industry must belong to the Gabonese. Locals need to know how to run and maintain it, instead of relying on outside NGOs or scientists from the United States and Europe. This will not only ensure that ecotourism is more sustainable but also that locals will see more benefits. The Gabonese need a larger role in this effort than simply serving as bellhops and taxi drivers. They need to be trained as tour guides, park service staff, hotel managers, regional planners, and even scientists monitoring the impacts on the environment. Part of this effort should take place in the schools, where the government should emphasize the natural sciences and apply innovative ideas used in other ecotourism countries, such as state scholarships for individuals wanting to work for the country's park service.

\section{Developing local interest}

Creating a local stake in ecotourism development will be a challenge. Almost any development initiative is doomed to fail if locals do not feel invested in the process. Some general steps for developing local vested interests are mentioned in the previous education sections. Another approach to stimulating interest in ecotourism is by promoting Gabonese tourism. Local tourism will probably not produce great economic gains; but it does allow the Gabonese to learn more about their country, and it encourages a local stake in environmental conservation. An important management step for advancing local tourism is creating a 
tiered entrance fee system, similar to Costa Rica's, where foreigners pay more than locals to visit parks. This will help discourage mass foreign tourism, but allow locals to enjoy these territories.

\section{Staying Small}

Large-scale tourism can have terrible effects on the environment and local development. Economically speaking, small-scale tourism produces less tourism leakage. Staying small is one area of concern where Gabon can learn from Costa Rica and other destinations that have mistaken mass tourism as ecotourism. Gabon's initiative will most likely fail at conservation and economically aiding local communities if it becomes too large.

\section{Limited development around parks}

Limiting the number of visitors to ecotourism sites to a scientifically sound and practically manageable number is vital. For some sites that are particularly vulnerable, such as the small, beachfront Mayumba National Park, this may be a very small number. For some that are geographically larger, Minkébé National Park for example, the number may be quite high or not an issue at all. Those hoping for ecotourism success in Gabon should not become disheartened if individual parks do not make money. State revenue is fungible. Not every park, or even most, needs to make a profit for the system to remain sustainable. A large park such as Minkébé, which can be frequented by thousands of visitors, can fund several smaller parks that may not 
produce profits but are equally valuable. Gabon's government and park managers should also keep in mind that an individual park might be quite economically successful even if the park service does not produce a profit. The surrounding community's economy may be doing extremely well because of the tourists that the park draws. A growing economy and increased employment means more tax revenue. Besides caps on the number of visitors to areas, there are other ways to prevent mass tourism. One is to strictly control development at tourist sites with steps like limiting the number and size of hotels around sites and national parks.

\section{Promoting small business}

Small businesses that cater to smaller numbers are much better at environmentally sensitive development. Smaller businesses could be greatly aided by a tax system that heavily taxes large resorts, if not expressly forbids them. There are many possible state-initiatives to support small business. For example, small hotels can be featured on the government's tourism website with the option for visitors to book their room on the web. State efforts such as this can help small businesses to better compete against big, foreign-owned resorts. Individual initiatives should capitalize on communities where there is already some of the necessary infrastructure, such as hotels, restaurants, to support tourism. As one ecotourism author told me, 
"That way you are supporting the local community; and to tell the truth, the local community really knows best about what needs to be provided."

Ecotourism will create a number of opportunities for small business initiatives, e.g., operating a water taxi and setting up small private land reserves. There are numerous models for supporting small business development in the Third World. One of the best models is that of the Grameen Bank, a micro-credit program created by Muhammad Yunus in Bangladesh. In coming up with the Grameen Bank, Yunus created a loan program that is almost the opposite of loans from traditional banks. Loans from Grameen are small, often around $\$ 25$. To overcome the psychological barrier of parting with large sums of money, Yunus instituted loan repayments spread out over a year that are so small that borrowers barely miss the money. ${ }^{11}$

One of the more critical components to the success of the Grameen Bank is that, like Six-S, social pressure is used to encourage the repayment of loans. Loan applicants are required to join small groups that share the responsibility for the loan being repaid. A loan must be repaid to allow for future loans to other individuals in the group, creating a support network to encourage repayment and help the borrower if she is in trouble. ${ }^{12}$ This process creates the vital social capital needed to support development initiatives such as ecotourism. A more unified base is more effective at tackling problems that require grassroots movements. 
Most borrowers either go into raising livestock or into

handiwork, manufacturing, or other trades. The Grameen Bank not only improves the economic wellbeing of individuals, but it also has an empowering effect on its borrowers, which is all the more important when you consider that 90 percent are women. The success of the Grameen Bank has inspired similar programs, some government funded and others started by private groups, to popup around the world. ${ }^{13}$ Gabon's ecotourism efforts could be greatly aided if a similar program popped up there.

\section{Gabon's Image}

Many tourists, especially environmentally conscious ones, will not visit Gabon unless it fixes some major problems that have tarnished the country's image.

Price gouging

To many potential visitors, Gabon is simply too expensive. This is a real problem since many travelers with fixed budgets such as backpackers and students are some of the most environmentally and culturally conscious travelers. Price gouging is part of the reason why the cost of living in Gabon is so high. The challenge with price gouging may be convincing business owners and government officials that it is a problem in the first place. Logically some hotel or restaurant owners may feel they should be able to charge any price they want as long as some people are willing to buy their product. But price gouging will hurt 
business in the long run. If the costs of goods and services are too high, the majority of travelers will stay away. Price gouging for services such as hotels, restaurants, and taxies will also prevent average Gabonese from traveling to tourist sites, and it would be tragic if the Gabonese were not able to experience the beauty of their own country. Hunting of rare wildlife

The bushmeat trade must be brought under control if ecotourism efforts are going to succeed. The frequently mentioned suggestion for reducing the bushmeat trade is of course serious punishments for people who kill, sell, or enable the trade of protected animals. A sincere clampdown on the bushmeat trade would be extremely difficult, however, without addressing some of the causes of corruption within enforcement agencies. A few suggestions for creating the necessary political development to address corruption have been mentioned in this chapter. But at best, it will take several years before policing agencies are brought under control.

Aside from addressing corruption, the government and NGOs can assist enforcement agencies by providing the necessary funding and tools to police the trade. Scientists are providing some of these tools such as hi-tech animal monitoring systems. Treaties of cooperation between Gabon and neighboring countries should also help reduce poaching. In early 2005, Gabon and 9 other Central African countries signed a treaty committing to preserve the region's forests and wildlife. Included in the 
treaty are references to international teamwork for policing bushmeat. This is a good step since wildlife and hunters do not recognize national boundaries. In the past, park staff have had to watch helplessly as poachers escaped across country borders. ${ }^{14}$

The government should not limit itself to reactive solutions to reduce hunting such as tougher fines. There are a number of proactive approaches that also should be employed. One good idea that the country's national park council has already expressed interest in is using former poachers as park guides and rangers since they know the terrain and wildlife. This not only provides new employment for poachers but also increases their pay since guides typically make three times more money than poachers. ${ }^{15}$

Demand can also be reduced through public information campaigns that condemn the killing of rare wildlife and dispel all the myths of benefits from bushment. These campaigns should also explain the significance of losing Gabon's rare wildlife. One of my survey respondents who did development work in Gabon stressed explaining that unless poaching is stopped many animals will not be around for future generations and asking, "What kind of Gabon would it be without elephants, giant pangolin, and gorillas?"

Lastly, studies have suggested that as wealth increases in rural Gabon the consumption of bushmeat also rises. Therefore, any approach to reducing bushmeat consumption must coincide with poverty 
alleviation efforts, especially in rural areas where poverty and malnutrition from a lack of protean sources are worst. ${ }^{16}$

\section{Marketing Gabon}

Many educated and well-traveled people have never even heard of Gabon, and most of those who have heard of it only know of it as an oilproducing state in Central Africa. The national government could aid ecotourism efforts by developing a national marketing plan to be followed for the next few years. People in the West need to know about Gabon, the beauty and importance of its environment, and why if they do not support the country's tourism efforts the rainforest may disappear.

Agricultural Problems

A number of challenges to ecotourism in Gabon are in some way tied to the country's poor agricultural industry. For example, a stronger agricultural industry that relies less on logging will help reduce the amount of consumption of bushmeat and the level of tourism leakage.

\section{Helping Farmers}

It is rough being a farmer in Gabon. Initiatives that have previously been mentioned in this chapter like the Grameen Bank can help Gabonese farmers. Farmers can also be helped with education on environmentally sound farming techniques that will produce food for the country, especially rural populations. A number of models for developing sustainable agricultural practices are available in Central Africa. One previously mentioned one is the GBM, which uses seminars, among 
other practices, to inform farmers on how to maintain the fertility of their land. The GBM emphasizes organic farming and crop rotation as methods to allow for the long-term use of land. Organic farming in particular is an important issue when it comes to preserving Gabon's environment. Many farmers in Central Africa have been duped into believing that pesticides and chemical fertilizers are best for their farms. Besides the horrible environmental effects of these chemicals, however, they also reduce the lifespan of farmland by inhibiting the regenerative capacity of the soil. These products are also a major expense for poor, rural farmers. ${ }^{17}$ Farmers who intend to grow cash crops should practice both cash and subsistence farming to ensure some food security. ${ }^{18}$

There are a number of policy approaches available for promoting sustainable farming, such as agricultural conservation easements designed to protect farmland. Conservation easements are legal agreements used by landowners to permanently protect land. They provide tax incentives to land owners to prevent development on environmentally sensitive areas. Agricultural conservation easements, however, can be used to keep farmland in use for agricultural proposes, provide tax breaks to farmers, or both. ${ }^{19}$

In addition to conservation easements, aid in the form of both money and training should be provided to farmers who have either lost their land or are not able to use it as the result of a park's creation. Here the government could copy some of the methods used by Costa Rica and 
the United States when they were creating some of their national parks and national forests. During my time with WildLaw, I did a great deal of work with national forests, especially those in the Southeastern United States. While researching the creation of the Tuskegee National Forest, the smallest national forest in the country, I came across the Resettlement Administration's successful practices used to both create a national forest and empower poor black sharecroppers in the rural Southeastern United States. Farmers and their families were relocated to nearby government-purchased land. Farmers were given their own farmland and taught better farming techniques. Individuals who were not moved were often given work creating the forest. The situation turned out to be a win-win for most involved. Costa Rica used many of these same techniques in creating its park system. Similar approaches should work well in Gabon.

\section{Controlling logging}

The government needs to reduce-or at least not expand-the current level of logging. Commercial logging is the number one threat to Gabon's forests. That said, it must be taken into account that the logging industry is the second largest employer in Gabon. A pragmatic approach to sustainable development will have to include working with commercial loggers. For this to happen, there needs to be management policies that apply good science and honest, open public participation. Individuals with groups such as WildLaw have found that the most 
successful national forest rangers have used public participation on logging projects to negotiate agreements that both environmentalists and loggers accept as reasonable. Public policies should also provide compensations to farmers and companies that have lost logging concessions.

\section{Economic Diversification}

Ecotourism is not going to replace oil revenue. That is why there must be an investment in other development options. A more diverse economy will also help with some of the other problems mentioned in this study, such as the temptation of logging. Putting your eggs in one basket

Tourism is an industry with more ups and downs than most others, and it is often anything but predictable. Natural disasters, war, disease, and all sorts of other factors that a host country has absolutely no control over can negatively affect the level of tourism. Because of this fact, the best managed tourism destinations do not overly rely on their tourism industry. It would be great if tourism were to become the number one revenue producer in Gabon. But it should never be responsible for more than a fifth of the country's revenue.

Ecotourism: Good for Gabon and the World Ecotourism development within Gabon will no doubt have to be combined with other development initiatives. Many of the initiatives mentioned in this chapter, e.g., Six-S, the Grameen Bank, are not tied 
specifically to environmental development or ecotourism. Yet they have experienced success because they support the development of social capital and local cohesiveness. These are the necessary ingredients to deal with problems such as government corruption and the lack of political development within local communities. It would be near impossible to reach the optimistic goals of ecotourism in Gabon without addressing these problems. One of the best options available for NGOs and Western governments to help protect Gabon's environment is by supporting village-level development that is predicated on locals managing their own resources. This will produce social capital at the base, and in turn should help to produce the grassroots momentum needed to confront the problems mentioned in this study that are tied to Gabon's lack of political development.

Other governments can also help by increasing funding for the Congo Basin Forest Partnership. The United States could certainly afford to increase its rather modest initial proposal of $\$ 53$ million dollars to be spread between six countries. With the current administration, an increase in funding may not be likely; but environmental NGOs should work to convince the government and American donors that funding the effort is in all of our best interests.

The purpose of this study was to examine the possibilities of creating a successful ecotourism industry in Gabon. Throughout this thesis, I attempt to explain some of the necessary steps for ecotourism 
development and some of the major challenges that lay ahead. Given all of the political, social, and economic problems in Gabon, it is understandable why some may wonder why ecotourism is an answer for Gabon at all. What one should keep in mind, however, is how truly important the country's environment is. The Congo Basin is often described as the world's second lung, after the Amazon. We would all suffer with a continued loss of this forest. Gabon's forests serve as a huge carbon reservoir, sequestering between 0.94 and 5.24 gigatons of carbon. ${ }^{20}$ In additional to the global environmental impacts, think of what a loss it would be for the world to lose the spectacular plant and wildlife diversity of Gabon and all the scientific research that is coming from it.

In the ideal world, Gabon's environment would be preserved and only used for scientific research. This, of course, is not realistic. There is a need to deal with the dual problems of underdevelopment and environmental vulnerability. Ecotourism is not the perfect solution for both of these problems-but it is certainly the best available. 
Notes

${ }^{1}$ R.K. Blamey, "Principles of Ecotourism," in The Encyclopedia of Ecotourism, ed. David B. Weaver (London: CABI Publishing, 2000), 6.

2 Janet Matthews Information Services. Quest Economics Database, "Gabon: Country Profile," Africa Review World of Information (23 September 2003).

3 Julie Fisher, Nongovernments: NGOs and the Political Development of the Third World (West Hartford, CT: Kumarian Press, 1998), 107.

${ }^{4}$ Ibid.

5 Wangari Matthai, "Trees for Democracy," The New York Times, 10 December 2004, A41.

${ }^{6}$ Bernard J. Lecomte and Anirudh Krishna, "Six-S: Building upon Traditional Social Organiztions in Francophone West Africa," in Reasons for Hope: Instructive Experiences in Rural Development, ed. Anirudh Krishna, Norman Uphoff, and Milton J. Esman (West Hartford, CT: Kumarian Press, 1997), 75 - 76.

7 Ibid., 87.

8 Julie Fisher, Nongovernments, 8.

9 Marc Thibault and Sonia Blaney, "Sustainable Human Resources in a Protected Area in Southwestern Gabon," Conservation Biology 51, no. 3 (June 2001), 591 - 594.

10 Ibid., 594.

${ }^{11}$ Muhammad Yunus, Banker to the Poor: Micro-lending and the Battle Against World Poverty (New York: PublicAffairs, 1999), 61-63.

12 Ibid.

13 "Global Grass-Roots Banking," The New York Times, 27 July 1995, A22.

${ }^{14}$ Andrew Gray, "Central African Leaders Pledge to Save Forests," Reuters News Wire, 5 February 2005. 
15 Paul Miles, "Gabon primes national parks in tourist push," The Daily Telegraph (London), 13 November 2004, 4.

16 David S. Wilkie et al., "Role of Prices and Wealth in Consumer Demand for Bushmeat in Gabon," Central Africa," Conservation Biology 19, no. 1 (February 2005): 273.

17 Wangari Matthai, The Green Belt Movement: Sharing the Approach and the Experience (New York: Lantern Books, 2004), 44.

18 Ibid., 45.

19 Gary Paul Green and Anna Haines, Asset Building \& Community Development (Thousand Oaks, CA: Sage Publications, 2002), 171.

20 Deborah Farmer ed., "A First Look at Logging in Gabon," Global Forest Watch, 2000, http://www.globalforestwatch.org/common/gabon/ english/report.pdf (accessed 9 May 2005), 8. 


\section{BIBLIOGRAPHY}

Behler, Deborah A. "Gabon Raises the Bar: WCS has been instrumental in the recent decision by Gabon to protect an unprecedented portion of its land for wildlife." Wildlife Conservation November/December 2002, 6-7.

Blacke, Beatrice and Anne Becher. The New Key To Costa Rica, 17th ed. Berkeley, CA: Ulysses, 2002.

Blamey, R.K. "Principles of Ecotourism." In The Encyclopedia of Ecotourism, ed. David B. Weaver. London: CABI Publishing, 2000.

Browne, Malika and Jan McGirk. "Welcome to the kingdom ruled by fear: Tourists are still beating a path to Nepal as its bloody civil war." The Independent 23 August 2004.

Buckley, Ralf. Case Studies in Ecotourism. Cambridge, MA: CABI Publishing, 2003.

Chepesiuk, Ron. "The Ecotourism Explorer." Environmental Health Perspective 108, no. 5 (May 2000): A2 11.

"Costa Rica." Lonely Planet, http:/ /www.lonelyplanet.com/destinations / central_america/costa_rica/ (accessed 6 April 2005).

Curry, Andrew. "J. Michael Fay: He walked clear across Africa's wild heart." U.S. News \& World Report 131, no. 7 (20 August 2001): 60.

Decalo, Samuel. The Stable Minority: Civilian Rule in Africa, 1960-1990. London: FAP Books, 1998.

"Defence official says remaining illegal residents will be tracked down." BBC Summary of World Broadcasts 17 February 1995.

"Deportation of 639 illegal immigrants said to make 70,000 since midFebruary." BBC Summary of World Broadcasts 5 April 1995. 
Duffy, Rosalee. A Trip Too Far: Ecotourism, Politics, \& Exploitation. Sterling, VA: Earthscan, 2002.

Eagles, Paul F.J. "Understanding the Market for Sustainable Tourism." in Linking tourism, the environment, and sustainability: Topical volume of compiled papers from a special session of annual meeting of the National Recreation and Park Association, ed. Stephen F. McCool and Alan E. Watson. Minneapolis, MN: Recreation and Park Association, (12-14 October 1994): 95.

"Ebola Strikes in Gabon." Animal Welfare Institute Quarterly 51, no. 1 (winter 2002).

Emerson, Jed. "Understanding Risk: The Social Entrepreneur and Risk Management." In Enterprising Nonprofits: A Toolkit for Social Entrepreneurs, ed. J. Gregory Dees, Jed Emerson, and Peter Economy. New York: John Wilety \& Sons, 2001.

Farmer, Deborah ed., "A First Look at Logging in Gabon," Global Forest Watch, 2000, http://www.globalforestwatch.org/common/gabon/ english/report.pdf (accessed 9 May 2005).

Fa, John E. and Jessica Meeuwig. "Bushmeat and food security in the Congo Basin: linkages between wildlife and people's future." Environmental Conservation 30, no. 1 (2003), 71-78.

Fieldhouse, D.K. The Colonial Empires: A Comparative Survey from the Eighteenth Century. New York: Delacorte Press, 1967.

Finlay, Hugh, et al. Africa on a Shoestring, $9^{\text {th }}$ ed. Oakland, CA: Lonely Planet Publicans, February 2001.

Fisher, Julie. Nongovernments: NGOs and the Political Development of the Third World. West Hartford, CT: Kumarian Press, 1998.

Ford, Neil. "Gabon: Hard times on the horizon." African business, no. 292 (December 2003): 48.

Fower, Alan. "Options, Strategies and Trade-offs in Resource Mobilization." In The Earthscan Reader on NGO Management, ed. Michael Edwards and Alan Fowler. Sterling, VA: Earthscan Publications Ltd., 2002.

"Global Grass-Roots Banking." The New York Times 27 July 1995, A22. 
Goldsmith, Edward. "Development as Colonialism." In The Case Against the Global Economy: And for a Turn to the Local, ed. Jerry Mander and Edward Goldsmith. San Francisco, CA: Sierra Club Books, 1996.

Graham, Jr., Frank. "Rainforest TV." Audubon 92 (November 1990): 2223.

Green, Gary Paul and Anna Haines. Asset Building \& Community Development. Thousand Oaks, CA: Sage Publicans, 2002.

Hammond, Richard. "The Better travel guide." The Observer 28 March 2004, 2.

Honey, Maratha. "Giving a Grade on Costa Rica's Green Tourism." NACLA Report on the Americas 36, no. 6 (1 May 2003): 39-46.

Honey, Maratha. Ecotourism and Sustainable Development: Who Owns Paradise? Washington, D.C.: Island Press, 1999.

Janet Matthews Information Services. "Country Profile: Gabon." Africa Review World of Information 26 September 2002.

Janet Matthews Information Services. "Country Profile: Gabon." Africa Review World of Information 23 September 2003.

Johnston, Rob. "Defining Your Mission." In Enterprising Nonprofits: A Toolkit for Social Entrepreneurs, ed. J. Gregory Dees, Jed Emerson, and Peter Economy. New York: John Wilety \& Sons, 2001.

Koblah, Divine and Brahima Ouedraogo. "African-labor: No longer wanted, migrants flee Gabon." IPS-Press Service/Global Information Network 15 February 1995.

Koerner, Brendan. "Why Does It Cost So Much to Live in Gabon?" Slate Magazine, 16 January 2003, http://slate.msn.com/id/2077091/ (accessed 31 March 2005).

Kreg Lindberg, "Economic Impacts." In The Encyclopedia of Ecotourism, ed. David B. Weaver. London: CABI Publishing, 2000.

Kretzmann, John and John McKnight. "Assets-based Community Development." National Civic Review 85, no. 4 (winter 96). 
Lawson, Antoine. "Monkey brains off the menu in Central Africa." Reuters News Service 1 January 2002.

Lawson, Antoine. "Rights-Gabon: Caretakers exploiting child laborers." Inter Press Service 11 April 2002.

"Manuel Antonio National Park." CentralAmerica.com, http://centralamerica.com/cr/parks/momanuelantonio.htm (accessed 6 April 2005).

Matthai, Wangari. The Green Belt Movement: Sharing the Approach and the Experience. New York: Lantern Books, 2004.

Matthai, Wangari. "Trees for Democracy." The New York Times 10 December 2004, A41.

McGreal, Chris. "Aboard the slave ship of despair: Traffickers buying up the young in west Africa." The Guardian 16 April 2001, 10.

McLaren, Deborah. Rethinking Tourism and Ecotravel: The Paving of Paradise and What You Can Do to Stop It. West Hartford, CT: Kumarian Press, 1998.

McNeil, Jr., Donald G. "The Great Ape Massacre." The New York Times Magazine 9 May 1999, 54.

Miles, Paul. "Gabon primes national parks in tourist push." The Daily Telegraph (London) 13 November 2004, 4.

"Millions pledged to protect Congo Basin." Environmental News Service, 5 September 2002, http:/ 64.233.187.104/search?q=cache: GeR8HwYyJYIJ:ens-newswire.com/ens/sep2002/2002-09-0509. asp+environmental+news+service, +congo+basin, +september+5,+2002\&hl=en (accessed 31 March 2005).

Messone, Nelson N. and Jean-Germain Gros. "The Irony of Wealth: Democratization in Gabon." In Democratization in Late TwentiethCentury Africa: Coping with Uncertainty, ed. Jean-Germain Gros. Westport, CT: Greenwood Press, 1998.

"No hardship to tourists in Nepal: Official." PeaceJournalism.com, 5 February 2005, http:/ / peacejournalism.com/ReadArticle.asp? ArticleID=1138 (accessed 31 March 2005). 
Okamba, Louis. "Possible Ebola Outbreak in Congo." Associated Press Wire 11 June 2002.

Orams, Mark B. "Types of Ecotourism." In The Encyclopedia of Ecotourism, ed. David B. Weaver. London: CABI Publishing, 2000.

Palti, Leslie. "The Chronicle Interview." UN Chronicle 41, no 3 (September-November 2004): 6-8.

Peterson, Dale, Eating Apes. Los Angeles: University of California Press, 2003.

Quammen, David. "Almost Cannibalism." The New York Times 15 June 2003, A16.

Quammen, David. "Saving Africa's Eden.” National Geographic, September 2003, 49-72.

"Québec Declaration on Ecotourism." World Tourism Organization, 19-22 May 2002, http:/ /www.world-tourism.org/sustainable/IYE/ quebec/anglais/declaration.html (accessed 25 January 2005).

Reed, Michael C. "Gabon: A Neo-Colonial Enclave of Enduring French Interest." The Journal of Modern African Studies 25, no. 2 (June 1987): 283-320.

Rich, Jeremy. "Une Babylone Noire: Interracial Unions in Colonial Libreville, c. 1860-1914." French Colonial History 4 (2003): 145169.

Rouguet, Pierre, et. al. "Wild Animal Mortality Monitoring and Human Ebola Outbreaks, Gabon and Republic of Congo, 2001-2003.” Emerging Infectious Diseases 11, no. 2 (February 2005).

"Starbucks president and Congo explorer a winning brew at Seattle event." Conservation Frontlines winter 2003, 1.

Starmer-Smith, Charles. "Eco-friendly tourism on the rise." The Daily Telegraphy 6 November 2004, 4.

Tagne, David Ndachi. "Illegal logging denudes Cameroon's forests." Agence France-Presse Wire 4 February 2005. 
Tangley, Laura. "Portraits in the Wild: In an unexplored region of Africa's Atlantic coast, an innovative photographer captures Gabon's bountiful wildlife." Smithsonian October 2003, 61-62.

Thibault, Marc and Sonia Blaney. "Sustainable Human Resources in a Protected Area in Southwestern Gabon." Conservation Biology 15, no. 3 (June 2001): 591 - 595.

"Tortuguero National Park." CentralAmerica.com, http://centralamerica.com/cr/parks/motortuguero.htm (accessed 6 April 2005).

UN Integrated Regional Information Networks. "UN Mediates Dispute Over Corisco Bay Islands." African News 25 January 2004.

U.S. Department of State. "Gabon Human Rights Practices, 1992." Department of State Dispatch 3, no. 00 (March 1993).

U.S. Department of State. "International Boundary Study: Republic of the Congo (Congo) - Democratic Republic of the Congo (Zaire)." The Geographer office of the Geographer Bureau of Intelligence and Research. September 8, 1979. http:/ / www.law.fsu.edu/library/collection/LimitsinSeas/ IBS127.pdf (accessed 7 May, 2005).

Wallace, David Rains. The Quetzal and Macaw: The Story of Costa Rica's National Parks. San Francisco, CA: Sierra Club Books, 1992.

Wearing, Stephen. "Exploring Socio-cultural Impacts on Local Communities." In The Encyclopedia of Ecotourism, ed. David B. Weaver. London: CABI Publishing, 2000.

Weaver, David B. and Regina Schlüter. "Latin America and the Caribbean." In The Encyclopedia of Ecotourism, ed. David B. Weaver. London: CABI Publishing, 2000.

"What is Ecotourism?" The Ecotourism Society, 2003, www.ecotourism.org/index2.php?what-is-ecotourism (accessed 31 March 2005).

"WHO says infected gorilla responsible for lethal Ebola outbreak in Gabon." Associated Press Wire 10 April 2002. 
Wilkie, David S., et al. "Role of Prices and Wealth in Consumer Demand for Bushmeat in Gabon, Central Africa." Conservation Biology 19, no. 1 (February 2005): $268-274$.

World Tourism Organization. "Ecotourism, now one-fifth of market." World Tourism Organization News 1, no. 6 (1998).

Wright, Philip. "Sex Tourism: Lessons Learned in Costa Rica." BBC News 20 June 2004.

Yates, A. Douglas. The Rentier State in Africa: Oil Rent Dependency \& Neocolonialism in the Republic of Gabon. Trenton, NJ: Africa World Press, 1996.

Yunus, Muhammad. Banker to the Poor: Micro-lending and the Battle Against World Poverty. New York: PublicAffairs, 1999. 


\section{APPENDIX A \\ INSTITUTIONAL REVIEW BOARD APPROVAL LETTER}

June 11, 2004

Robert Hunt

POS 4600

rwhunt@ilstu.edu

Thank you for submitting the research protocol titled, Where the Green Money Grows:

Assessing the Prospects of Ecotourism in Gabon, for review by the Illinois State University Institutional Review Board (IRB). The IRB has reviewed this research protocol and effective 6/11/2004, has classified this protocol as Exempt from Further Review.

This protocol has been given the IRB number 2004-0240. This number should be used in all correspondence with the IRB.

This classification of this protocol as Exempt from Further Review is valid only for the research activities, timeline, and subjects described in the above named protocol. IRB policy requires that any changes to this protocol be reported to, and approved by, the IRB before being implemented. You are also required to inform the IRB immediately of any problems encountered that could adversely affect the health or welfare of the subjects in this study. Please contact Nancy Latham, Assistant Director of Research, at 438-8451 or myself in the event of an emergency. All correspondence should be sent to:

Institutional Review Board

Campus Box 3330

Professional Development Building

Telephone: 438-8451

It is your responsibility to notify all co-investigators (Daniel Chand), including students, of the classification of this protocol as soon as possible.

Thank you for your assistance, and the best of success with your research.

Beverly Smith, Chairperson

Institutional Review Board

Telephone: $438-7645$ 


\section{APPENDIX B \\ INFORMED CONSENT FORM}

Informed Consent Document:

This is a study of the feasibility of ecotourism in the West-Central African republic of Gabon. The purpose of this study is to determine a) whether ecotourism is a reasonable option for Gabon and b) what form an ecotourism model should take. Your participation in this interview should take approximately 30 to 45 minutes.

All participation with this study is voluntary, and interviewees may refuse to participate or discontinue the interview at any time without penalty. All interview materials and answers will be held by the researcher for one year prior to the interview before being destroyed.

For any additional questions before or after the interview, participants may contact the researcher by phone at (334) 613-3857 or e-mail at Daniel@wildlaw.org. Participants are also welcomed to contact the researcher's thesis chair, Dr. Robert Hunt, at (309) 4385945 or by e-mail at rwhunt@ilstu.edu.

You can also contact the Illinois State University Institutional Review Board (IRB) at:

Bruce Deason

Campus Box 3330

Normal, IL 61790-3330

(309) 438-8451

Thank you for your participation.

Participant's Name (print):

Participant's Signature:

Date: 


\section{APPENDIX C \\ SURVEY FOR EXPERTS ON ENVIRONMENTAL PROTECTION \\ OR ECOTOURISM}

Current Job title:

How long have you worked on conservation or ecotourism issues?

Please draw on your professional background to answer the following questions. If possible, please use an example of something you experienced for some of the questions.

1. In your opinion, what would constitute a successful ecotourism program in a country such as Gabon (i.e. rainforest environment)?

E.g., benefits for local population, environmental benefits, etc...

2. What should be the top priority for any ecotourism program in Gabon?

3. Besides nonprofits, what steps should governments, businesses, and other institutions in the West take to establish ecotourism in Gabon?

4. What are the target groups that you believe would be interested in ecotourism in Gabon?

E.g., environmentalists, nature enthusiasts, etc...

5. What type of a role should the local community play in any ecotourism program in Gabon? What type of role should outside groups play?

6. From your perspective, please briefly define what ecotourism is? How does it differ from other development models?

7. What are possible negative consequences (e.g., environmental, cultural, political...) of ecotourism that you could foresee happening in Gabon? 


\section{APPENDIX D \\ SURVEY FOR EXPERTS ON GABON OR CONGO BASIN}

Current Job title:

How long have you worked on conservation or with the Congo Basin?

Please draw on your professional background to answer the following questions. If possible, please an example of something you experienced for some of the questions.

1. In your opinion, what would constitute a successful ecotourism program in a country such as Gabon?

E.g., benefits for local population, environmental benefits, etc...

2. What should be the top priority for any ecotourism program in Gabon?

3. Besides nonprofits, what steps should governments, businesses, and other institutions in the West take to establish ecotourism in Gabon?

4. What are the target groups that you believe would be interested in ecotourism in Gabon?

E.g., environmentalists, nature enthusiasts, etc...

5. What unique challenges does Gabon present to those trying to establish a sustainable ecotourism model?

E.g., economic or political instability, underdeveloped infrastructure, lack of international name recognition, physical isolation from West, etc...

6. In addition to ecotourism and oil, what other opportunities for economic development are available to Gabon? How do these other opportunities compare to ecotourism?

7. Briefly, what suggestions would you make to solve the bushmeat trade in Gabon? 